\title{
Arctic Freshwater Natural Capital in the Nordic Countries
}

(1I) Nordic Council of Ministers

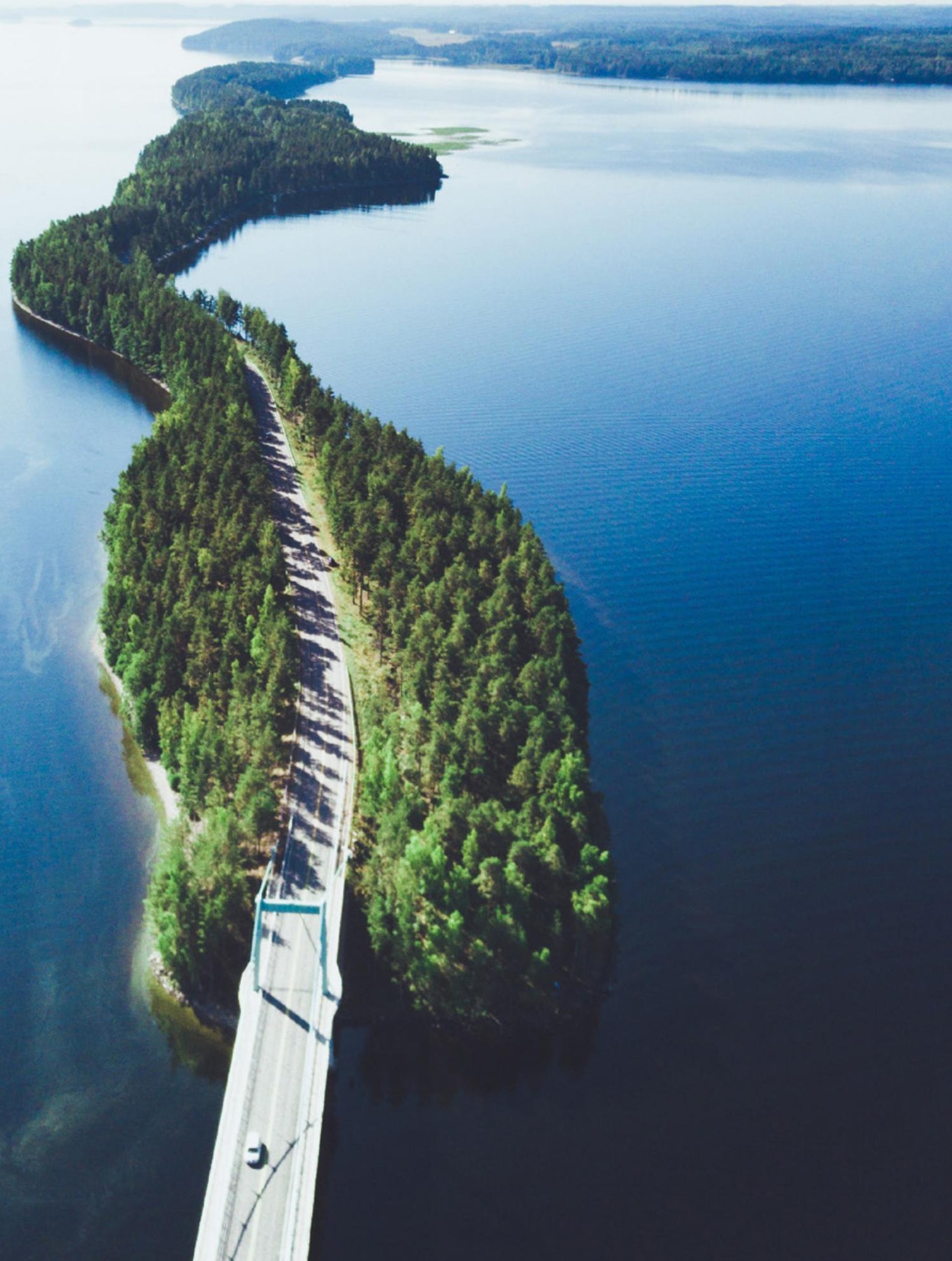





\section{Arctic Freshwater Natural Capital in the Nordic Countries}

Soile Oinonen, Johanna Pohjola, Jani Salminen, Virpi Lehtoranta, Tuija Mattsson, Sari Väisänen, Luke Dodd, Gerdur Stefansdottir, Eivind Aronsen, Marcus Carson, Tea Nõmmann and Doan Nainggolan

TemaNord 2019:505 


\section{Arctic Freshwater Natural Capital in the Nordic Countries}

Soile Oinonen, Johanna Pohjola, Jani Salminen, Virpi Lehtoranta, Tuija Mattsson, Sari Väisänen, Luke Dodd, Gerdur Stefansdottir, Eivind Aronsen, Marcus Carson, Tea Nõmmann and Doan Nainggolan

ISBN 978-92-893-5980-1 (PRINT)

ISBN 978-92-893-5981-8 (PDF)

ISBN 978-92-893-5982-5 (EPUB)

http://dx.doi.org/10.6027/TN2019-505

TemaNord 2019:505

ISSN $0908-6692$

Standard: PDF/UA-1

ISO 14289-1

(c) Nordic Council of Ministers 2019

Cover photo: Taneli Lahtinen

Print: Rosendahls

Printed in Denmark

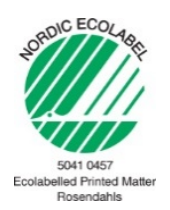

Disclaimer

This publication was funded by the Nordic Council of Ministers. However, the content does not necessarily reflect the Nordic Council of Ministers' views, opinions, attitudes or recommendations.

\section{Rights and permissions}

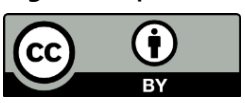

This work is made available under the Creative Commons Attribution 4.0 International license (CC BY 4.0) https://creativecommons.org/licenses/by/4.0

Translations: If you translate this work, please include the following disclaimer: This translation was not produced by the Nordic Council of Ministers and should not be construed as official. The Nordic Council of Ministers cannot be held responsible for the translation or any errors in it.

Adaptations: If you adapt this work, please include the following disclaimer along with the attribution: This is an adaptation of an original work by the Nordic Council of Ministers. Responsibility for the views and opinions expressed in the adaptation rests solely with its author(s). The views and opinions in this adaptation have not been approved by the Nordic Council of Ministers. 
Third-party content: The Nordic Council of Ministers does not necessarily own every single part of this work. The Nordic Council of Ministers cannot, therefore, guarantee that the reuse of third-party content does not infringe the copyright of the third party. If you wish to reuse any third-party content, you bear the risks associated with any such rights violations. You are responsible for determining whether there is a need to obtain permission for the use of third-party content, and if so, for obtaining the relevant permission from the copyright holder. Examples of third-party content may include, but are not limited to, tables, figures or images.

Photo rights (further permission required for reuse):

Any queries regarding rights and licences should be addressed to:

Nordic Council of Ministers/Publication Unit

Ved Stranden 18

DK-1061 Copenhagen $\mathrm{K}$

Denmark

Phone +4533960200

pub@norden.org

\section{Nordic co-operation}

Nordic co-operation is one of the world's most extensive forms of regional collaboration, involving Denmark, Finland, Iceland, Norway, Sweden, and the Faroe Islands, Greenland and Åland.

Nordic co-operation has firm traditions in politics, economics and culture and plays an important role in European and international forums. The Nordic community strives for a strong Nordic Region in a strong Europe.

Nordic co-operation promotes regional interests and values in a global world. The values shared by the Nordic countries help make the region one of the most innovative and competitive in the world.

\section{The Nordic Council of Ministers}

Nordens Hus

Ved Stranden 18

DK-1061 Copenhagen K, Denmark

Tel.: +453396 o200 www.norden.org

Download Nordic publications at www.norden.org/nordpub 



\section{Contents}

Preface

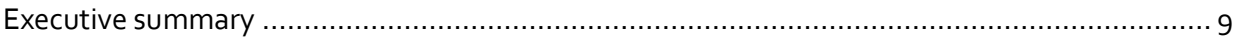

1. Arctic freshwaters, ecosystem services and natural capital .......................................11

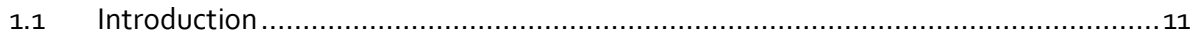

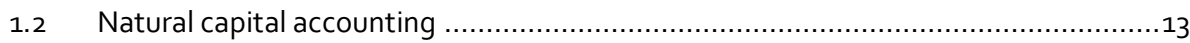

1.3 Challenges in developing natural capital accounting ........................................18

2. Freshwater resources in the Nordic Arctic: sectoral demands, pressures, and externalities .27

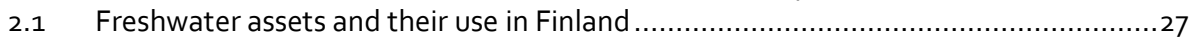

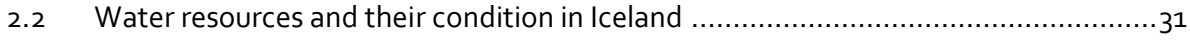

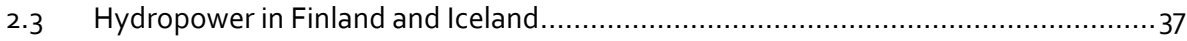

3. How can freshwater natural accounting be used in governing Arctic freshwater resources? 39

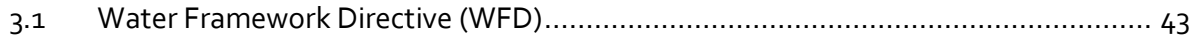

3.2 Managing human activities in complex, multi-level systems: scale and role ............ 44

3.3 Challenges and opportunities in the WFD institutional context .......................... 48

3.4 Economic valuation and disproportionate costs.......................................... 51

4. Current status of environmental accounting in the Nordic countries................................55

4.1 A survey on the status of environmental accounts ....................................... 56

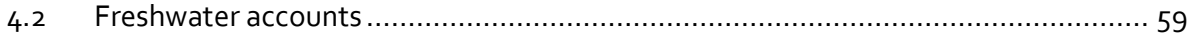

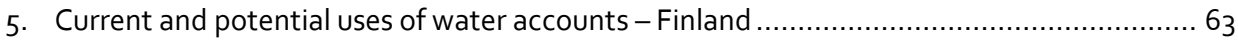

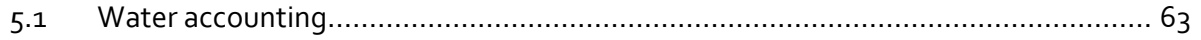

5.2 Experiences from the compilation of the national water accounts........................ 66

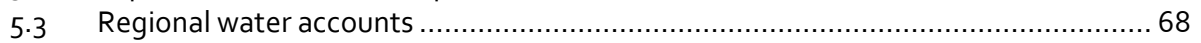

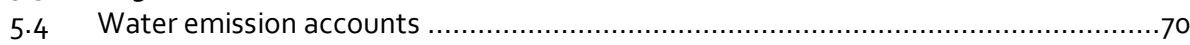

$5.5 \quad$ Water footprints of products and services .................................................... 73

6. Economic and environmental impact analyses using ecosystem accounting.....................75

6.1 Scenarios, indicators and models applied in the analyses....................................75

6.2 Impact of a new pulp mill on water use ...................................................... 77

6.3 Impact of a new pulp mill on forest asset and on trade-offs between forest based

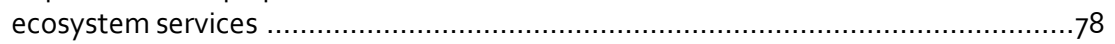

6.4 Trade-offs between environmental and economy-wide impacts in monetary and

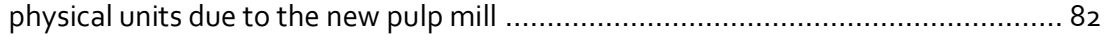

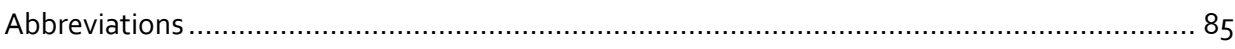

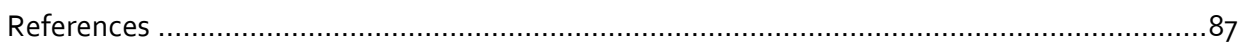

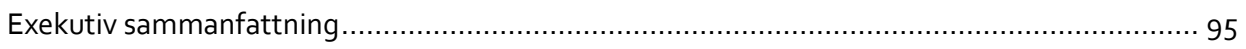




\section{Preface}

Arctic Freshwater Natural Capital project is a flagship project for the Finnish Presidency of the Nordic Council of Ministers. The project is coordinated by the Finnish Environment Institute with the support of the project partners - Icelandic Meteorological Office, Norwegian Institute for Nature Research, Stockholm Environment Institute and Aarhus University. We would like to acknowledge the contributions of the Natural Resources Institute Finland for the utilization of forest sector model FinFEP and Satu Turtiainen for the design of several of the included figures.

The main themes of the Presidency are water, nature and people. During the years 2016-2018, the project has addressed all three themes through the lens of environmental accounting which allows for the systematic linking of environment and economy. This report extends and deepens the understanding of the importance of and challenges related to the sustainable management of Nordic freshwater ecosystems and the services they provide. Thus it can be seen as a continuum from previous Nordic Council of Ministers reports including Nordic Capital in a Nordic Context (Mazza et al. 2013), Ecosystem Services in Nordic Freshwater Management (Magnussen et al. 2014), Valuation of Ecosystem Services from Nordic Watersheds (Barton et al. 2012b) and Socio-Economic Importance of Ecosystem Services in the Nordic Countries (Kettunen et al. 2012). The subject and methods of the Arctic Freshwater Natural Capital project embody the themes of the Presidency and promote synergy between the Nordic's water, nature and people. This report explores and demonstrates how the links between the environment and economy can be systematically analysed, and we hope that it will be useful in achieving the objectives of the Finnish Chairmanship of the Arctic Council 2017-2019 and the Nordic and Arctic collaborations moving forward.

November 2018

Soile Oinonen

Project coordinator 


\title{
Executive summary
}

\author{
What is the problem?
}

Current indicators of economic growth (e.g., GDP) do not adequately consider sustainability, while environmental indicators alone fail to acknowledge the economic needs of a society. Previous international attempts to address this issue have produced mixed results. Both the EU (Biodiversity Strategy) and the UN (Sustainable Development Goals) continue to call for actions to assess the status and future of ecosystem services and their contribution to the welfare of current and future generations. The need for systematic analysis of economy-environment interactions has never been so urgent.

\section{What is the desired outcome?}

Widespread deployment of a tool indicating the sustainability of freshwater ecosystem use, their contribution to economic growth, and the costs of degradation of freshwater ecosystems; that can then be used as an input into forward looking economic models assessing economic and environmental impacts of e.g. economic investments (pulp mills) or environmental investments (e.g. environmental policies, nature protection).

\section{Status and proposed solutions}

Natural Capital Accounting (NCA) can be the tool that fills the gap separating current economic and environmental indicators. Development of NCA has progressed considerably, making NCA now ready for wider application throughout the Nordic countries. Background on the relevant concepts of natural capital and ecosystems services, the development and application of NCA, and some ongoing challenges are all presented in the context of Nordic freshwater resources in Chapter 1.

Freshwater is generally plentiful in the Nordic Arctic but water quality issues can lead to water scarcity and economic losses. Chapter 2 provides information on the availability and quality of freshwater resources in the Nordic region and illustrates interactions between the economic sectors and freshwater ecosystems. Which sectors are water intensive, what kind of pollution do they produce, what are their economic contributions and how many jobs do they offer?

The Water Framework Directive of the European Union is the key policy addressing the sustainable use of freshwater ecosystems in the Nordic countries and is highly 
synergistic with the development and application of NCA. Chapter 3 illustrates how the Directive is requesting and reporting information that could be used as an input for various accounts. Moreover, it shows how the development of accounts could be used in conducting economic analyses requested by the directive.

Environmental accounting is already being widely deployed in the Nordic countries but development and deployment remains uneven. Chapter 4 presents the current status of environmental accounting in the Nordic countries including existing accounts, user profiles, current challenges and future development plans. Chapter 5 provides an overview of the regulatory structure of the WFD and the different roles played by people who might use water accounts to inform their decisions or advocacy. It also illustrates the development of water accounts for 195 economic sectors in Finland and how the information can be used at a regional scale. Potential applications towards the development of water emission accounts, water footprints, ecosystem accounts and the use of input-output modelling are discussed.

Natural Capital Accounting can help analyse the expected economic and environmental consequences of investments. Chapter 6 illustrates the trade-off between provisioning and cultural ecosystem services in monetary terms.

\section{Recommendations}

- Educate environmental scientists and environmental economists on environmental and ecosystem accounting statistical standards and frameworks;

- Test the existing data sets resulting from environmental valuation studies in an accounting framework;

- Engage WFD policy experts to determine how they could contribute in the development of ecosystem accounts and provide information on how they could apply the accounts to give informed policy advice;

- Allocate resources for the development of environmental and ecosystem accounts and their regular update e.g. in every 5 years;

- Use accounting information to develop indicators for Sustainable Development Goals;

- Integrate environmental and economic accounts with economic models to analyse the impact of investments and policies. 


\section{Arctic freshwaters, ecosystem services and natural capital}

Doan Nainggolan, Marcus Carson, Tuija Mattsson, Sari Väisänen, Luke Dodd, Tea Nõmmann, Johanna Pohjola, Virpi Lehtoranta and Soile Oinonen

\subsection{Introduction}

Freshwater resources (lakes, rivers, glaciers, groundwater) are vital in all areas of the globe, yet they are often taken for granted in the Northern/Arctic regions. Water is not only important for environmental reasons - it is essential for human societies and economies. The comprehensive evaluation report "Arctic Freshwater Synthesis" published in 2015 summarizes the scientific background for ongoing changes in the Arctic freshwater system and the importance of hydrological and ecological processes regarding its functioning (Prowse et al. 2015). Dramatic changes are occurring in the region due to a number of drivers, including various global and regional processes such as climate change and increased use of natural resources. The increasing precipitation and temperature brought on by climate change is a particularly important driver altering the hydrology of the Arctic, modifying the presence and flow of freshwater through the region's lakes, rivers and wetlands. As the Arctic gets warmer, it also becomes easier to exploit its natural resources, placing even greater pressure on freshwater ecosystems (Prowse et al. 2015). Additionally, these drivers contribute to changing biodiversity within Arctic freshwater ecosystems, which in turn will have profound effects on the distribution, abundance and quality of freshwater ecosystems and their associated habitats (CAFF 2013).

One important lens for understanding freshwater resources is through the relationship between these resources as capital and the ecosystem services they provide. Natural capital has long been recognized to be an important source of wealth in addition to man-made capital and labour. Natural capital refers to both renewable resources, like water and forests, and non-renewables, like oil and minerals. It can also take intangible forms, for example as information stored in species and ecosystems. While natural capital provides a reference to stocks, ecosystem services denote the flow of benefits from the stocks to society, either directly or through processes that involve contributions from other sets of capital-manufactured and human capitals (Costanza et al. 1997). 
The Millennium Ecosystem Assessment (Millennium Ecosystem Assessment $2005 \mathrm{p}: 168)$ notes that "because the water cycle plays so many roles in the climate, chemistry, and biology of the Earth, it is difficult to define it as a distinctly supporting, regulating, or provisioning service". Such is the case in the Arctic where freshwater systems provide a wide range of important ecosystem services, including support for biodiversity, habitat for commercial and subsistence species, drinking water, transport, and recreation. Indirectly, they also affect a wide variety of functions including carbon sequestration, Arctic Ocean acidity levels, and broader hydrological cycles (CliC/AMAP/IASC 2016). Figure 1 identifies some of the key ecosystem services associated with Arctic freshwaters in the Nordic countries. As interactions between catchments and freshwaters play an important role, it is of high relevance to include some of the key ecosystem services from terrestrial biomes, e.g., carbon storage and sequestration, and water purification.

Figure 1: Arctic freshwater ecosystem services in the Nordic countries

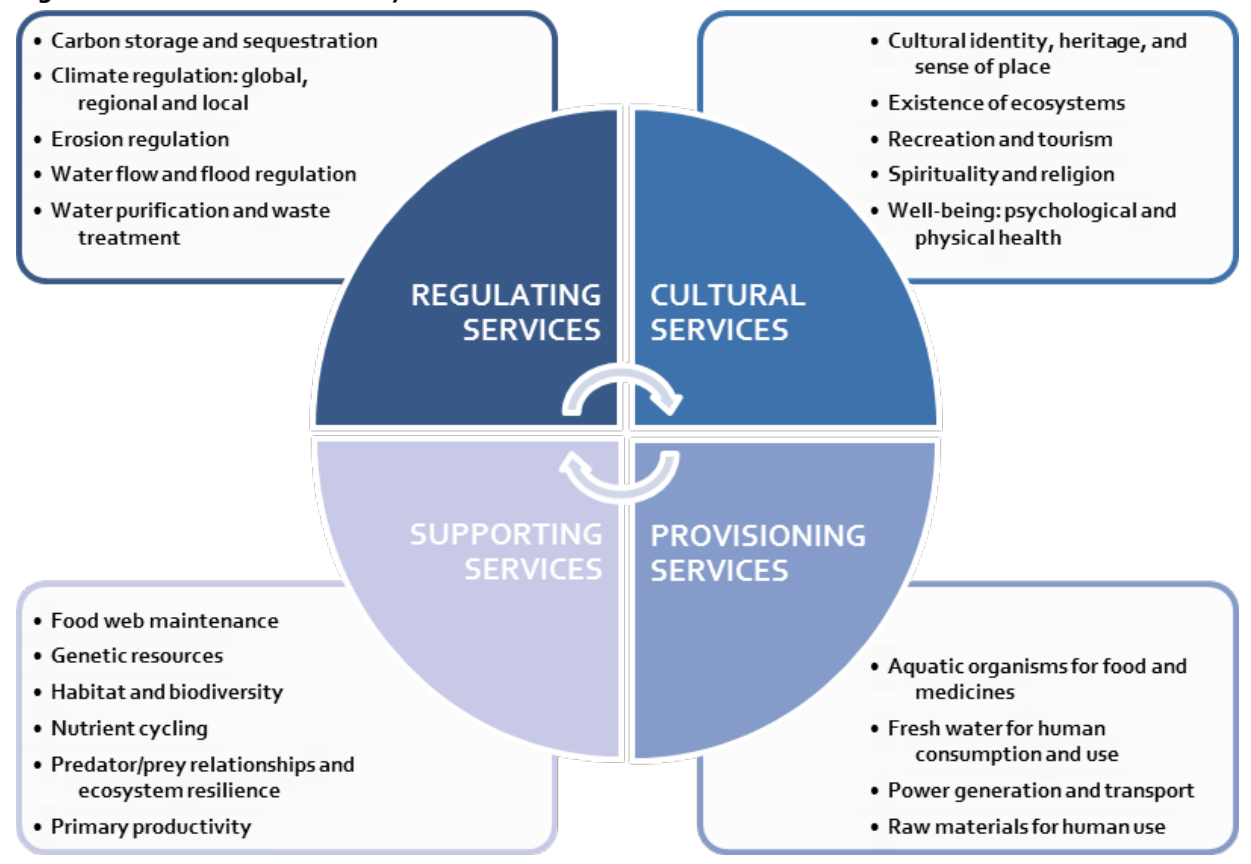

Source: Building on the Millennium Ecosystem Assessment 2005, Kettunen et al. (2012) and Barton et al. (2012).

Eventually, the intensity and continuity of ecosystem service flows are subject to the condition of the natural capital of interest. As illustrated in Figure 2, human and economic activities can have some impacts on the stream of different ecosystem services of Arctic freshwater even if the extent of the stock remains relatively unchanged. In most cases, trade-offs are inevitable where the flow of a selection of services may be augmented while the others may decline. Because of the difference between stocks and ecosystem service flows, the concept of natural capital can be useful as a framework for joining stocks and service flows together to help define the benefits to society over time in terms of improvements in ecological status of water bodies. 
To support water management, improvement or degradation of the ecological status can be evaluated in monetary terms. For example in the context of freshwater ecosystems, the Nordic Council of Ministers report on Valuation of Ecosystem Services from Nordic Watersheds (Barton et al. 2012b) gives an overview of Nordic valuation studies of watershed ecosystem services and assesses the use of economic valuation in the context of the Water Framework Directive (WFD).

Figure 2: Human and economic activities (e.g. a new mine or factory) can have impacts on the flow of different ecosystem services

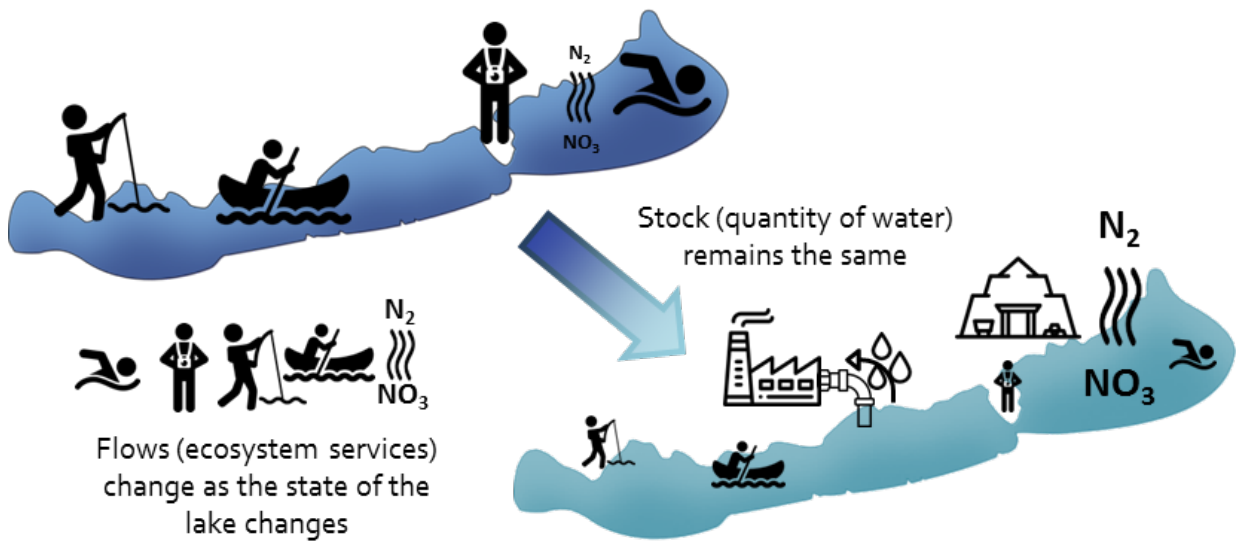

Note: Human and economic activities (e.g. a new mine or factory) can have impacts on the flow of different ecosystem services in Arctic freshwaters even if the extent of the stock remains relatively unchanged. Size of the ecosystem service icon indicates magnitude of the flow. In some cases, the flow of a selection of services may be augmented while others may decline. Denitrification is used as an example of a water purification service: denitrification is a microbially facilitated process where nitrate $\left(\mathrm{NO}_{3}\right)$ is reduced and ultimately produces molecular nitrogen $\left(\mathrm{N}_{2}\right)$ through a series of intermediate gaseous nitrogen oxide products. The process is a primary method for removing biologically available nitrogen from the environment and is a valuable ecosystem service for maintaining water quality.

Arctic freshwater resources are fundamental to the wellbeing of societies; natural capital and ecosystem service concepts can be a valuable tool for increased understanding leading to better management. It is clear that in the Arctic context, research to inform sustainable management of freshwater ecosystems, as one of the most important natural capitals in this region, is crucial for ensuring sustainable flows of services from these capitals. To this end, an accounting approach can offer important insights into finding the balance between meeting economic interests and ensuring the capacity of the stock to deliver various services both in the present and future.

\subsection{Natural capital accounting}

Sustainable management of natural capital is key to ensuring the flow of various ecosystem services, and an accounting strategy can provide standards for organizing information in a way that is meaningful and useful for assessing management choices impacting these service flows. Natural Capital Accounting 
(NCA) offers a tool for capturing the full contribution to economic performance of a country's or region's natural capital, beyond what is accounted for in a conventional measure or indicator (e.g. Gross Domestic Product, GDP) (World Bank 2018, https://www.wavespartnership.org/). NCA aims to provide an explicit picture of the relationship between economic development and the state of the natural wealth and assets of a country. This can be expressed in terms of both quantity and quality at different time and spatial scales. As such, it demonstrates the consequences of a country's economic growth on the exploitation of its natural resources; the degradation/decline of the different types of natural capital. The overall goal of NCA is therefore to account not only what is recorded in market activities (e.g. timber production) but also capital not reflected in market transactions (e.g. regulating services such as water purification) (La Notte et al. 2017, La Notte and Dalmazzone 2018).

NCA is a broad concept covering accounts for stocks of natural resources and pollutants; flows of energy, materials, water, etc.; as well as for assets and flow accounts for ecosystem services. It also captures other related aspects such as environmental expenditures and the monetary gains accruing from those expenses. Outputs of NCA can inform better decision-making and the development of strategies for managing the economy and natural resources. NCA offers an important basis for various policy initiatives, e.g., EU Biodiversity Strategy. Action 5 of the Strategy requires $\mathrm{EU}$ member states to assess and value ecosystem services and integrate this information into accounting and reporting systems (European Commission 2011).

The development of NCA has its origins in the concerns for resource scarcity due to oil crises in the 1970s, and the economic and social costs of environmental degradation (e.g., National Research Council 1999, Heal and Kristrom 2005). Economists contributed to the debate by investigating what the proper index would be for measuring the well-being of society, and developing criteria to judge whether the economy is on a sustainable path (e.g., Weitzman 1976, Hartwick 1990, Dasgupta and Mäler 2000, Asheim and Weitzman 2001). These studies suggested that NCA should focus on changes in stocks of natural capital and pollutants as an indicator of the sustainable economic growth. The development of NCA also relates to the development of augmented accounts that expand the standard definition of GDP, e.g., by incorporating non-market activities like unpaid household work. The importance of developing natural capital accounts and adopting indicators to measure real well-being was also recognized by the United Nations and other international organizations, with the establishment of accounts beginning in the 1980s. The newly developing wealth accounts responded to the suggestion of economists to focus on stocks and their changes. Table 1 provides a summary of key milestones in the development of NCA. 
Table 1: Key timeline in the development of natural capital accounting system in the Nordic countries and beyond

\begin{tabular}{|c|c|c|}
\hline \multirow{2}{*}{ Year } & \multicolumn{2}{|r|}{ Milestones } \\
\hline & Bywho? & What was done? \\
\hline $1990 \mathrm{~s}$ & World Bank & $\begin{array}{l}\text { Construction of a global database for comprehensive wealth accounts. The natural } \\
\text { capital component included agricultural land, forest land, protected areas and subsoil } \\
\text { assets. In order to follow the change of wealth (as stock) of nations, the flow indicator } \\
\text { Adjusted Net Saving (ANS) was developed. As Gross Domestic Product (GDP) indicates } \\
\text { the economic growth, then ANS indicates whether the growth is sustained. }\end{array}$ \\
\hline 1992 & United Nations (UN) & $\begin{array}{l}\text { Agreement to establish integrated environmental and economic accounting was } \\
\text { concluded at the Earth Summit in } 1992 \text { (Rio de Janeiro) and is part of the programme of } \\
\text { action-Agenda } 21 .\end{array}$ \\
\hline 1992 & Sweden & $\begin{array}{l}\text { The Swedish Environmental Accounts Commission (Ministry of Finance) had Statistics } \\
\text { Sweden develop physical environmental accounts and the National Institute of } \\
\text { Economic Research to investigate the feasibility of developing monetary environmental } \\
\text { accounts. }\end{array}$ \\
\hline 1997 & Norway & $\begin{array}{l}\text { The NOREEA-project (the Norwegian Economic and Environmental Accounts project) } \\
\text { developing Hybrid accounts - National Accounting Matrix with Environmental Accounts } \\
\text { (NAMEA) - air emissions; Environmental taxes; Solid waste accounts and Industries' } \\
\text { environmental protection investments and current expenditures. }\end{array}$ \\
\hline 2010 & World Bank & $\begin{array}{l}\text { The global partnership of Wealth Accounting and the Valuation of Ecosystem Services } \\
\text { (WAVES) was initiated to help developing countries build their natural capital account } \\
\text { capacities. }\end{array}$ \\
\hline 2011 & EU & $\begin{array}{l}\text { Reporting of the first three modules of the Regulation on European Environmental } \\
\text { Economic Accounts (EU No 691/2011) 1) Air emissions accounts; 2) Environmental } \\
\text { taxes; and 3) Economy-wide material flow accounts become mandatory. }\end{array}$ \\
\hline 2012 & $\begin{array}{l}\text { UN Statistical } \\
\text { Commission }\end{array}$ & Launch of the System for Environmental and Economic Accounts (SEEA). \\
\hline 2013 & $\begin{array}{l}\text { UN Statistical } \\
\text { Commission }\end{array}$ & Adoption of the new SEEA Experimental Ecosystem Accounting (SEEA-EEA). \\
\hline 2013 & Norden & $\begin{array}{l}\text { Publishing of "Natural Capital in a Nordic context: Status and Challenges in the Decade } \\
\text { of Biodiversity". }\end{array}$ \\
\hline 2013 & $\begin{array}{l}\text { Nordic ministers for } \\
\text { the environment }\end{array}$ & $\begin{array}{l}\text { Establishment of the Ad Hoc working group on Complementary Measures for Welfare } \\
\text { with a mandate to point out directions on how to integrate economic and } \\
\text { environmental information and analysis through existing statistics. }\end{array}$ \\
\hline 2014 & EU & $\begin{array}{l}\text { The next three compulsory modules were adopted by Eurostat: 4) Environmental } \\
\text { protection expenditure accounts; 5) Physical energy flow accounts; and 6) } \\
\text { Environmental goods and services sector accounts. }\end{array}$ \\
\hline 2017 & 65 countries & Signing of the WAVES partnership communique on natural capital accounting. \\
\hline 2018 & World Bank & $\begin{array}{l}\text { Publishing of improved estimates of } 141 \text { countries' natural capital covering the period of } \\
1995 \text { to } 2014 \text { in the report "The Changing Wealth of Nations 2018: Building a } \\
\text { Sustainable Future". }\end{array}$ \\
\hline
\end{tabular}

The implementation of NCA has become a more prominent issue since the launch of the UN Statistical Commission of the System for Environmental and Economic Accounts (SEEA) in 2012 (https://seea.un.org/), providing an internationally recognized standard approach. The system consists of two frameworks; SEEA Central Framework (SEEA-CF, adopted in 2012) and SEEA Experimental Ecosystem Accounting (SEEA-EEA, adopted in 2013) (United Nations et al. 2014a, b). 
The two frameworks differ in terms of the boundary/definition of environmental assets/natural capital included in the respective accounting approaches. In principle, SEEA-CF deals with environmental assets as individual accounts (e.g. energy account, water account, timber account), whereas the SEEA-EEA contains physical and monetary accounts for ecosystems and considers how individual environmental assets interact as part of natural processes within a given spatial area.

For the application of the SEEA-CF, the present report focuses on water resources (see Chapter 5). At the international level, the need to secure access to clean water and the importance of freshwater management are reflected in the Sustainable Development Goals (SDGs). At the European level, political interests in protecting and managing water resources have been manifested, for example, through the EU Water Framework Directive (see Chapter 3 ) and the collection of water statistics by member states. However, water statistics alone are not necessarily meaningful for informing policy and decision making. On the contrary, water accounting serves such a purpose better, as it explicitly depicts the interaction between water resources, the economy, and various social dimensions. Water accounting reveals how and to what extent water resources contribute to the economy; and how and to what extent economic decisions in turn affect water resources (United Nations - SEEA-Water). As for the latter, the provision of emission accounts within water accounting demonstrates the importance of accounting for economic externalities (Infobox 1).

Infobox 1. Externalities

Economic activities (i.e., production and consumption of goods and services) of one agent can have consequences on others (third party) that do not enter into economic transactions of the good. In such situations, externalities arise. Externalities can manifest in two forms: positive and negative.

A classic example of a negative externality is pollution. Imagine a situation where a paper-producing factory upstream pollutes a river. Consequently, the quality of the water becomes degraded making it unsuitable for various activities downstream (e.g., fishing, swimming, etc.). Because of the economic activities of the industry upstream, other economic agents downstream (anglers, swimmers, etc.) experience loss of welfare. When the polluting agent upstream does not offer compensation to those agents affected downstream, the problem of externalities exists.

Positive externalities can be illustrated by how land management decisions made by private landowners can have beneficial effects to the wider society. One example is when a private landowner chooses to allocate a considerable proportion of their land for tree plantings; this will generate benefits that do not enter into the farm's financial accounting. Such benefits include $\mathrm{CO}_{2}$ sequestration, improved hydrological process including reduced erosion, and a rural landscape mosaic of recreational and aesthetic value.

As the name indicates, SEEA Experimental Ecosystem Accounting is still subject to experimentation, and revisions to the guidelines are on-going. Nevertheless, this accounting framework consistently views ecosystems as an integral entity as opposed to a disjointed perspective that deals with individual assets. This is reflected in the system's definition of ecosystem accounting as "a coherent and integrated approach to the assessment of the environment through the measurement of ecosystems, and 
measurement of the flows of services from ecosystems into economic and other human activity" (United Nations et al. 2014a). In principle, this requires accounting for ecosystems in both physical and monetary terms. However, because the monetary values of many ecosystems and services are not readily available from market data, valuation becomes an instrumental tool. Inclusion of non-market values is fundamental to ecosystem accounting, which strives to demonstrate the full value of ecosystems through their contributions to both non-market activities and those appearing through market transactions.

In developing an augmented accounting system, such as ecosystem accounting, different authors have highlighted the importance of close reference to the standard System of National Accounts (SNA) (Bartelmus et al. 1991, Bartelmus 2014). However, Hein et al. (2015) highlighted three areas where ecosystem accounting further extends the coverage of the SNA. Firstly, the contributions of ecosystems to the economy are made explicit in the ecosystem accounts. Secondly, ecosystem accounts include a wide range of ecosystem services; not just limited to provisioning services. Finally, ecosystem accounts treat ecosystems as a form of capital with the possibility to track degradation or enhancement in ecosystem assets for a given time period.

The SEEA-EEA offers some guidelines for operationalizing ecosystem accounting (https://seea.un.org/ecosystem-accounting) beginning with a series of distinct accounts (Figure 3). The Ecosystem Extent Account provides a starting point for ecosystem accounting by organizing information on the extent of different ecosystem types within a country in terms of area. The Ecosystem Condition Account then reflects the overall quality of these ecosystem assets in terms of their characteristics. Both of these accounts are expressed only in physical units. The Supply and Use accounts record the actual flows of ecosystem services supplied by ecosystem assets and used by economic units during an accounting period. Thus, they provide a link between ecosystem assets and economic and human activities, and can be compiled in both physical and monetary terms. Asset accounts are designed to record information on stocks and changes in stocks of ecosystem assets. This includes accounting for ecosystem degradation. In principle, the value of the asset should be calculated as a sum of values of all ecosystem services it provides. As indicated by the black dashed arrows, further calculation or processing of data from the physical accounts is most cases required when constructing the monetary accounts. 
Figure 3: Ecosystem Accounting Framework and the linkage with the Systems of National Accounts (SNA)

\section{Physical ecosystem accounts Monetary ecosystem accounts}

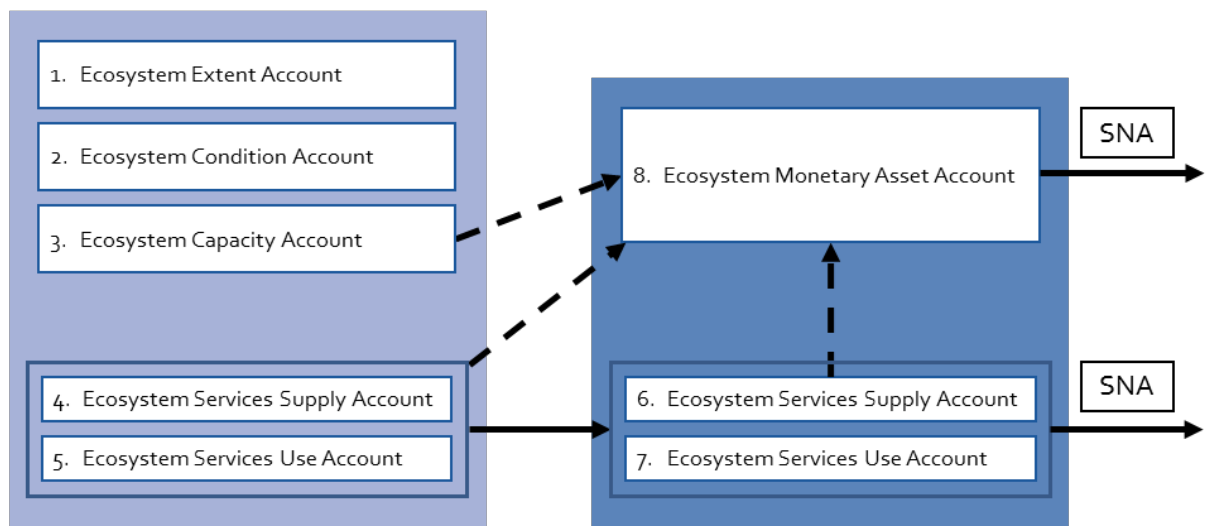

Note: Solid lines reflect direct connections, while dashed lines indicate connections where additional calculation or data processing is required.

Source: Adapted from Lai et al. (2018).

Ecosystem accounting takes into account the flows of ecosystem services to society while at the same time acknowledging the implications of economic and other human activities on ecosystems and their constituent services. Applying the SEEA-EEA framework in conjunction with policy/scenario analysis, Chapter 6 demonstrates trade-offs between different ecosystem services as a consequence of an economic decision. The applications draw on a case study from Finland, entailing new investment in pulp industry.

\subsection{Challenges in developing natural capital accounting}

The task of transforming the Natural Capital Accounting (NCA) framework into various applications remains confronted by a number of challenges. In this section, we touch upon three aspects:

1. The need for consistent methods for deriving monetary values of natural capital particularly pertaining to non-market goods and services (1.3.1-1.3.2) and how these values can then be used for accounting purposes (1.3.3);

2. The need to link natural capital accounting with SNA (1.3.4);

3. The scope for policy integration (1.3.5). 


\subsubsection{Valuation approaches}

Capturing the total economic value of natural capital is far from straightforward; to a large extent it is constrained by the absence of market prices for many environmental goods and services. To respond to this valuation challenge, a number of methods exist which can be generally divided into two groups: preference based and non-preference based methods. The preference based approach can be further classified into revealed preference or stated preference methods.

\section{Stated preference valuation methods}

The stated preference methods derive the economic value of environmental goods and services using direct responses from individuals to a series of hypothetical market scenarios presented through surveys. The most common stated preference methods are contingent valuation and choice experiment. In contingent valuation, respondents are directly asked to state their willingness to pay (WTP) for a given environmental improvement. An example of the application of contingent valuation is the valuation of groundwater protection in Denmark (Hasler et al. 2005).

In choice experiment, respondents are presented with multiple alternatives or scenarios which are characterized by the same set of attributes but the levels of the attributes vary across alternatives. Respondents are not directly asked to state their WTP; instead the WTP is estimated from costs presented in the various alternatives. Choice experiment generates richer information than contingent valuation and captures how individual respondents make trade-offs between attributes. In this way, choice experiment mimics the choices people make in a market setting better than the contingent valuation. An example of the application of choice experiment application is the valuation of water improvements to good ecological status in the context of Water Framework Directive (WFD) (Hanley et al. 2006).

WFD requires that all water bodies achieve "good ecological status" by 2027 . Since water quality is not a tradeable good in the market, stated preference methods may be applied to reveal the demand for water quality improvements, i.e., benefits for people. Survey techniques are used to ask people about the values they place on environmental changes if they were required to pay for them. Thus, a mean WTP value will indicate the amount of benefit people receive from an environmental change presented to them in a hypothetical scenario. For the survey, people are chosen from a random sample of the population to get a representative sampling of the benefits. Statistical analyses are carried out to find out respondent preferences towards environmental change and mean WTP values. Beside information about monetary benefits, decision makers and planners receive other valuable information regarding attitudes toward the survey topic. An example of the results from a Finnish environmental valuation study is presented in Chapter 3.3. 


\section{Revealed preference valuation methods}

Two major methods for revealed preference valuation include hedonic pricing and travel cost method. The premise of hedonic pricing is that the value of environmental goods or services can be approximated from the value of marketed commodities (e.g., properties). In this case, environmental goods and services serve as one of the determinants of the price of a related marketed commodity. As such, changes in the state of the environmental goods will be reflected through changes in the price of the commodities. One example of the use of hedonic pricing is for eliciting the value of water quality improvement in Finland based on the prices of recreational properties within the proximity of various water bodies (Artell 2014).

Travel cost method, as the name suggests, can be used for estimating the economic value of environmental goods and services on the basis of records of individual recreational activities. Expenses and opportunity cost of time incurred to individuals by these recreational activities provide the basis for inferring the economic value of the environmental goods and services. An example of the application of the travel cost method is for estimating the economic value of recreational salmon fishing in Teno River in Finland (Pokki et al. 2018).

\section{Non preference valuation methods}

Non preference valuation includes two primary methods: cost-based approaches and production function-based approaches. Cost-based approaches have three variants: 1) cost to society that would have been avoided in the presence of fully intact environmental goods and services (e.g. coastal protection provided by mangrove ecosystems); 2) cost of replacing natural systems with man-made solutions (e.g. construction of coastal defence); and 3 ) cost of restoring environmental goods and services. Production function-based approaches approximate the contribution of environmental goods and services to the production of particular commodities traded in the market. The application of these approaches requires sound understanding of the biophysical aspects of the relation between the state of the environmental goods and services being valued and the quantity of the marketed commodities being produced.

In the Nordic countries, there is a need for new and high quality valuation studies for several individual types of ecosystem services. Choice experiment and contingent valuation methods have been the most commonly utilized methods, but cost based methods and integrated modelling should also be conducted to diversify the perspectives of available valuation studies. Barton et al. (2012b) point out that spatial patterns of ecosystem service values and their dependence on distance, direction and scale are of importance if these ecosystem services are aimed to be a part of the ecosystem capital accounting. Future research should target solutions on how to scale up water body or watershed valuation data. Cost base approaches and damage functions are also worth studying in this regard (Barton et al. 2012b). 


\subsubsection{Double counting in valuation}

In ecosystem service valuation studies, double counting occurs when the monetary value of a service is counted more than once. Imagine a situation where for an ecosystem of interest (e.g., a river), four types of services are identified: regulating service, supporting service, provisioning service, and cultural service. Imagine further that the first two services are the underlying processes for the flow of the third service and that the quality of the third service eventually determines the realization of the fourth service. In such a situation, individually valuing each of the four services and aggregating the values leads to double counting. A focus on final-output services has been considered to have better alignment for monetary valuation (e.g., Hein et al. 2006, Ojea et al. 2012). Double counting can significantly compromise the accuracy and reliability of the valuation results; leading to inappropriate value estimates for accounting purposes.

Fu et al. (2011) identified the following factors as among the main sources of double counting in ecosystem service valuation:

- Ambiguous definitions and inconsistent classifications of ecosystem services;

- Poor understanding of ecosystem complexity;

- Inadequate recognition of exclusiveness and complementarities of individual ecosystem services;

- Spatio-temporal scale dependence of ecosystem services;

- Overlap and lack of cross-referencing between ecosystem service valuation methods.

They proposed that double counting can be minimized by:

- Identifying the spatio-temporal scales of ecosystem services;

- Valuing the final benefits obtained from ecosystem services;

- Establishing consistent classification systems for ecosystem services;

- $\quad$ Selecting valuation methods appropriate for the study context.

\subsubsection{From Valuation to Accounting}

Although techniques for valuing non-market environmental goods and services exist, there remain challenges, particularly pertaining to how results of these non-market valuation can be best aligned and used for ecosystem accounting. A basic principle for handling non-market activity in accounting systems is that they should be treated as if they were produced and consumed as market activities (Nordhaus 2006). Many valuation approaches deal with welfare changes as a consequence of changes in environmental quality (e.g. water quality improvement). It is therefore important to select appropriate valuation methods that can generate exchange values in order to be meaningful for the implementation of ecosystem accounting. 
Obst et al. (2016) provide a summary of existing valuation techniques along with a descriptive assessment of the suitability of the methods for ecosystem accounting purposes. For example, according to their assessment, suitable valuation methods include production function, hedonic pricing, and replacement cost methods. In comparison, economic values derived from stated preference or restoration cost method studies are deemed not directly appropriate for accounting purposes since the methods do not capture exchange values. Furthermore, they argued that, unlike exchange values, the use of shadow prices is not suitable for national accounting purposes as it will raise the issue of inconsistency in the accounts.

Droste and Bartkowski (2018) expressed disagreement with the conclusions from Obst et al. (2016) on the suitability of different valuation techniques for ecosystem accounting. They contend that the shadow price method is still appropriate for deriving a hypothetical exchange value of non-marketed ecosystem services; and that values generated from stated preference methods can be suitable for accounting purposes. They maintain that the applications of stated preference valuation are useful for ecosystem accounting purposes, provided that the results of the valuation demonstrate the marginal WTP for ecosystem service benefits. Under such circumstances, the valuation results are deemed consistent with the SEEA-EEA concept of value. Finally, they argue for restoration cost as a more appropriate method (than the replacement cost method) in estimating the value of ecosystem degradation. Nevertheless, they acknowledge the limitations of the restoration cost method and highlight the need for information on societal preference or demand.

In SEEA-EEA, the concept of exchange value is used to describe "market" price for those goods and services that are not exchanged in the market. Thus, it reflects the price at which ecosystem services and assets would be exchanged between a buyer and a seller if a market existed. As ecosystem service valuation has been largely approached by environmental economists from the demand side, not reflecting the notion of transactions between producers and consumers, the values derived are not consistent with the principle of exchange value adopted in System of National Accounts. To tackle this issue, an alternative approach, the so-called simulated exchange value method, has been proposed by Caparros et al. (2017).

The premise of the method is to utilise demand functions obtained from non-market valuation methods for simulating the entire market (demand, supply, competitive environment) of an ecosystem service of interest. The method ultimately seeks to estimate the price of the ecosystem service of interest if it were internalized. One of the key advantages of the simulated exchange value method is the fact that it "offers preference-based exchange value" which makes it suitable for use with ecosystem accounting (Caparrós et al. 2017).

Caparros et al. (2017) demonstrated the application of simulated exchange value method using the case of free access public recreation in Andalusian forests. They used results from contingent valuation studies for estimating demands for the recreation. The supply side is approximated by calculating direct and indirect costs borne by the government in association with the provision of public recreational services to free access visitors. It is assumed that public recreation operates under monopolistic 
competition in the short run. The results show estimated values of free access recreation to forests based on the simulated exchange value method to range between EUR 40 and EUR 50 per hectare. These values are relatively robust compared with the values estimated using compensating variants where the values are highly sensitive to the choice of model. Nevertheless, there remains scope for more applications of this simulated exchange value method.

\subsubsection{Integrating ecosystem accounting into SNA}

The full integration of ecosystem accounting with non-market services into systems of national accounting is a challenging task. There are four formats for integrating ecosystem accounting into standard national accounts according to SEEA-EEA guidelines; including (a) combined presentations, (b) extended supply and use accounts, (c) institutional sector accounts and (d) balance sheets (United Nations et al.2014a). Figure 4 illustrates how the four types of extended accounts result from integrating different information from ecosystem accounting into SNA. The following descriptions of these integration methods are based on the SEEA-EEA guidelines.

Figure 4: Integration of ecosystem accounting into SNA according to SEEA EEA guidelines

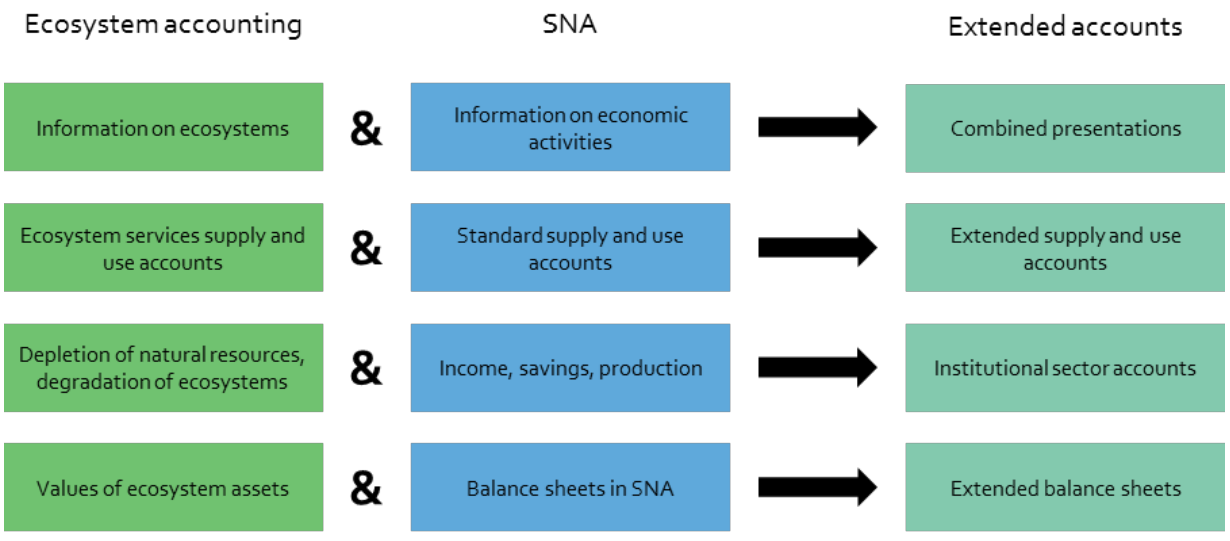

Source: UNEP et al. (2017).

Combined presentations are accounting tables that include information on ecosystems and the economy, and facilitates their comparison. The advantage of combined presentations is that valuation of ecosystem services or assets is not required. The combined presentation could, for example consist of flows of ecosystem services from a freshwater asset combined with the associated economic activity, as value added or employment related to freshwaters. In Chapter 6.4 combined presentations are utilized to illustrate environmental and economic impacts of a new pulp mill (Tables 17 and 18).

Extended supply and use accounts integrate the supply and use of ecosystem services into standard supply and use accounts in SNA. Extended supply and use accounts can be further elaborated into extended input-output tables. Integration implies the extension of production boundary with supplies of ecosystem services. 
Thus inclusion of ecosystem services always increases the total output of the economy. On the other hand, inclusion of ecosystem service increases value added only if it is used in final demand.

Some ecosystem services are used as an input in existing products of standard supply and use accounts and thus their contribution is already reflected in value added by SNA. An example of this is accumulation of timber used as an input in forestry. In this case, the total output of the economy is increased by the value of the forest accumulation. However, to avoid double-counting, the total value added is not changed. This is ensured by dividing the original value added in forestry between forestry and the forest asset. On the other hand, if the ecosystem service is used in final demand, both value added and value of final demand are increased by the value of the ecosystem service. Air filtration is an example of this type of ecosystem service.

Integrated sequence of institutional sector accounts focus on measures of income, saving, investment, value added and wealth. These measures can be adjusted with depreciation (i.e. consumption of fixed capital) of man-made capital in standard SNA, and with depletion of natural resources and degradation of ecosystems in extended accounting (see Infobox 2 on depletion and degradation). This adjustment is needed to take into account the cost of using man-made or natural capital against the incomes generated. The allocation of depletion and degradation between different sectors is not straightforward and affect the values of adjusted economic measures, such as income or savings for different institutions (e.g., producers, household, ecosystem, etc.). The allocation depends on the treatment of ecosystems, namely if they are treated as additional production units or as assets owned by existing economic units. In addition, if an ecosystem provides services to different sectors, depletion and degradation should also be divided between these sectors.

Extended and integrated balance sheets provide an extended measure of national and sectoral wealth by integrating the opening and closing values of ecosystem assets (in monetary terms) into the standard balance sheet of SNA, including values of assets and liabilities. Avoiding double counting is an important concern in this approach, because the SNA balance sheet already includes values related to natural resources, such as fish or forests (see Chapter 1.3.2). In addition, the value of land may consist of many ecosystem services, while typically also reflecting the value of alternative uses. Thus caution is needed in making adjustments to avoid double counting if land value is part of the SNA balance sheet.

However, this is only an overview of the integration process. Full integration involves several phases that have to be done before the values of ecosystem services, degradation and assets can be added in the standard economic accounting. Aggregation across ecosystem services and assets is considered in SEEA-EEA to be a major challenge in implementing these phases. Although the full integration is challenging, this ultimate goal should direct the development of the ecosystem service accounting in the earlier phases. 
Infobox 2. Depletion and degradation

Depletion

Depletion of natural resources in physical units is defined in SEEA-CF as "the decrease in the quantity of the stock of natural resource over an accounting period that is due to the extraction of the natural resource by economic units occurring at a level greater than that of regeneration" (United Nations et al. 2014b). For non-renewables, depletion equals the amount of extraction. New discoveries of resource do not affect the recording of the depletion since it is not regeneration.

For renewables, depletion occurs wherever extraction exceeds the regeneration, i.e. when extraction is above the level of sustainable yield. Sustainable yield depends on the population size and structure, and the impact of extraction is usually non-linear. Therefore some variation is allowed when considering whether the extraction is sustainable. The reduction in the amount of resource due to the catastrophic losses, i.e., the extreme weather, is not recorded as depletion.

Degradation

Ecosystem degradation is defined in SEEA-EEA as "the decline in an ecosystem asset over an accounting period" (UNEP et al. 2017). This is reflected in declines in ecosystem condition and/or declines in expected ecosystem service flows. Compared to depletion, ecosystem degradation has a broader scope since it refers to declines in a system that encompasses a range of different resources and various processes. The decline has to be caused by economic or other human activity while declines due to the natural influences and events are not considered. Furthermore, decline in ecosystem service flow is considered as degradation only if it is related to a weakened condition in the ecosystem. In the case of freshwater, the decline in an freshwater asset due to increased loading from a new mill or mining factory, as in Figure 2, is considered to be degradation while decline due to increased acidification caused by isostatic land uplift of acid sulphate soils or decline in use of fishing services due to the higher fishing fees are not.

\subsubsection{Challenges and opportunities in the integration of natural capital accounting into policy process}

Perhaps the best example of demand and use of environmental accounts is the international reporting of anthropogenic greenhouse gas emissions due to the UN Framework Convention on Climate Change. Presently at the European level, the key driver of the development of natural capital accounting is the EU Biodiversity Strategy to 2020 (European Commission 2011). Target 2 of the strategy aims to maintain and restore ecosystems. Actions to achieve the target include assessing the state of ecosystems and the economic value of ecosystem services, and promoting the recognition of these in European accounting and reporting systems. However, organising environmental data in a structured format according to an accounting standard is only the necessary first step in utilizing this information in policy processes and decision making.

Currently, accounting primarily serves the purpose of identifying issues by measuring the state of ecosystems and their services and providing the data for indicators and simple projections. In the development and implementation of policy actions to tackle identified problems, accounting information needs to be coupled with ecological and economic models. Such models enable long term projections and assessment of pros and cons for different actions from various perspectives. In policy 
response and policy implementation phases, accounts mainly provide data for economic models analysing policy targets and impacts. In policy monitoring and policy review phases, the accounts and derived indicators show whether the policy has affected the state of ecosystems and their services as intended. The accounting data can also be utilized in econometric modelling for ex post evaluation of effectiveness of implemented policy instruments.

Vardon et al. (2016) identify several reasons for the lack of "policy pull" in utilizing natural capital accounting in policy making. Firstly, they point out that previous efforts have focused on developing indicators of sustainability instead of developing policy models around accounting. Indeed, indicators are useful for identification of problems, but for policy analysis and decision support, detailed natural capital accounting is needed. Another explanation might be that NCA is still being developed and users might hesitate to apply the accounting practice before all technical issues have been solved. A deeper reason mentioned in Vardon et al. (2016) is political. Governments and policy makers may be reluctant to confront difficult decisions that might arise if environmental impacts were fully reported in economic policy planning.

To fully realize the potential of NCA in the advancement of sustainable development, cooperation between statisticians and scientists from different fields is needed. Moreover, government and policy makers are likely to find that making decisions based on better knowledge of long term environmental impacts can help avoid costly and avoidable mistakes. 


\title{
2. Freshwater resources in the Nordic Arctic: sectoral demands, pressures, and externalities
}

\author{
Jani Salminen, Gerður Stefánsdóttir, Tuija Mattsson and Luke Dodd
}

Generally speaking, freshwater resources are abundant in the Nordic Arctic. Precipitation is high and water is stored in freshwater bodies such as lakes, groundwater aquifers and glaciers. Water, in its various forms - water, snow and ice, is a valuable asset for many economic sectors. In Finland, both surface and groundwater are used for drinking water production, but groundwater is generally preferred and its use for this purpose is expected to increase. In the Finnish Lapland, however, only groundwater is used. In Iceland, northern Sweden and Denmark, most of the waterworks use groundwater as a water source. On the other hand, Norway and Greenland take most of their drinking water from surface water bodies.

However, the Arctic environment is vulnerable in many ways. Typically, species diversity is low, and a portion of the ecosystems are isolated ecological islands, ecosystems that are not in a direct connection to other similar environments. This causes these ecosystems to be highly vulnerable to disturbance, often unique, and plausibly non-restorable. Additionally, summers are short and characterized by relatively low average temperatures. Consequently, the productive season for flora and fauna remains short as well. The low temperatures also slow recycling and decomposition processes; increasing the risks of pollution (Prowse et al. 2015). In Iceland, for instance, environmental pressures are in most cases highly local and not intensive; pollution is primarily caused by lack of wastewater treatment. On the other hand, general atmospheric circulation patterns transport air pollutants to the Arctic from lower latitudes. Moreover, Arctic ecosystems are strongly affected by climate change, with warming estimated to be greater than the global average (IPCC 2018).

\subsection{Freshwater assets and their use in Finland}

Finland is a country with abundant freshwater resources. According to the most recent national water accounting, the volume of abstracted groundwater and fresh surface water are 0.3 and 2.7 billion cubic meters annually, respectively, where artificial recharge is included in the figure for groundwater (Salminen et al. 2018). Surface freshwater abstraction makes up $1.4 \%$ of the estimated total asset i.e. the estimated total fresh surface water volume (Lai et al. 2018). For groundwater, the ratio is much 
more challenging to calculate. If only groundwater formed in aquifers classified as valuable for water supply is taken into account, the portion of abstracted volume corresponds to $10 \%$ of the total volume. These aquifers, however, cover only $4.3 \%$ of the total land area of Finland and groundwater is formed and abstracted outside these areas as well. Due to the highly diverse geological settings around the country, the total volume of groundwater and the volume of groundwater annually formed cannot be reliably estimated - the presence and extent of groundwater varies greatly from place to place according to depth and composition of the subsurface layers above the bedrock. However, water accounts for Finland reveal that annually about 60 million cubic meters of groundwater is abstracted from wells or springs that are located in areas other than above aquifers valuable for water supply. National scale figures are, however, not well suited to evaluate the sustainable use of water resources nor do they reveal regional or local water scarcity issues. Moreover, water abstraction may take place in locations and regions where freshwater with sufficiently high quality is not available while abundant resources may be available in remote locations where their potential is unlikely to be harnessed. In the southern and western parts of Finland, artificial recharge is needed to fulfil the water requirements of the water utilities. Examples of this are densely populated areas like the capital and Turku regions. Relatively more rural areas, such as Southern Satakunta in western Finland, may also struggle with sufficient high-quality freshwater.

Various solutions have been applied in these areas to mitigate the problems related to scarcity of high quality freshwater. In Finland, a $120 \mathrm{~km}$ long tunnel running in the bedrock was constructed in the 1970 (completed in 1982) to introduce surface water from the lake Päijänne to the water-scarce capital region. The 100 million cubic meters introduced to the tunnel represents roughly $1 \%$ of the total annual flow of the lake. In 2011, a facility to produce artificial recharge started operation in the Virtaankangas aquifer, SW Finland, where raw water for the Turku region is abstracted (about 100,000 $\mathrm{m}^{3} / \mathrm{d}$ ). Raw water from river Kokemäenjoki is first pumped along a $30 \mathrm{~km}$ pipeline to the Virtaankangas aquifer to be infiltrated. Artificial groundwater is then introduced to Turku to a distance of $55 \mathrm{~km}$. The water uptake rate from river Kokemäenjoki is $0.7 \%$ of the average flow of the river.

\subsubsection{Finnish Lapland}

The state of freshwater resources in Finnish Lapland is generally "excellent" or "good" (Figure 5). Only one percent of the rivers and two percent of the lakes are in a "satisfactory" state or worse (Mitikka et al. 2017). As a whole, only about $75 \%$ of the lakes and rivers in Finland have an excellent or good ecological status, indicating the excellent general health of freshwaters in northern Finland. In Finnish Lapland, water quality is affected by a variety of stressors including the drainage of peatlands, forestry, agriculture and mining. Some rivers are in a near pristine state, whereas others show slight human impacts, e.g., occasional high values of hygienic indicator bacteria (Niemi 2010). Nutrient concentrations in river water have declined, but the flux of organic matter from the catchment is increasing. Pressure resulting from human 
activity is moderate and current problems are mostly local. However, mining, forestry and tourism are growing sectors in the area putting increasing pressure on surface water quality. Climate change and long-range transport of air pollutants are also affecting the freshwater quality in Finnish Lapland (Mitikka et al. 2017).

This subchapter focuses on the industries that are particularly distinctive in the economic sense in the Finnish Lapland and their impacts on sustainable water use and water quality. These industries - freshwater aquaculture, mining, manufacturing of pulp and paper, manufacturing of basic iron, steel and ferro-alloys, manufacturing of motor vehicles, tourism (accommodation and skiing centres) - are particularly well represented in this area in comparison with the national economy and together they also make a significant contribution to the regions' economy (Figure 5).

Figure 5: The most distinctive industries in the Finnish Lapland

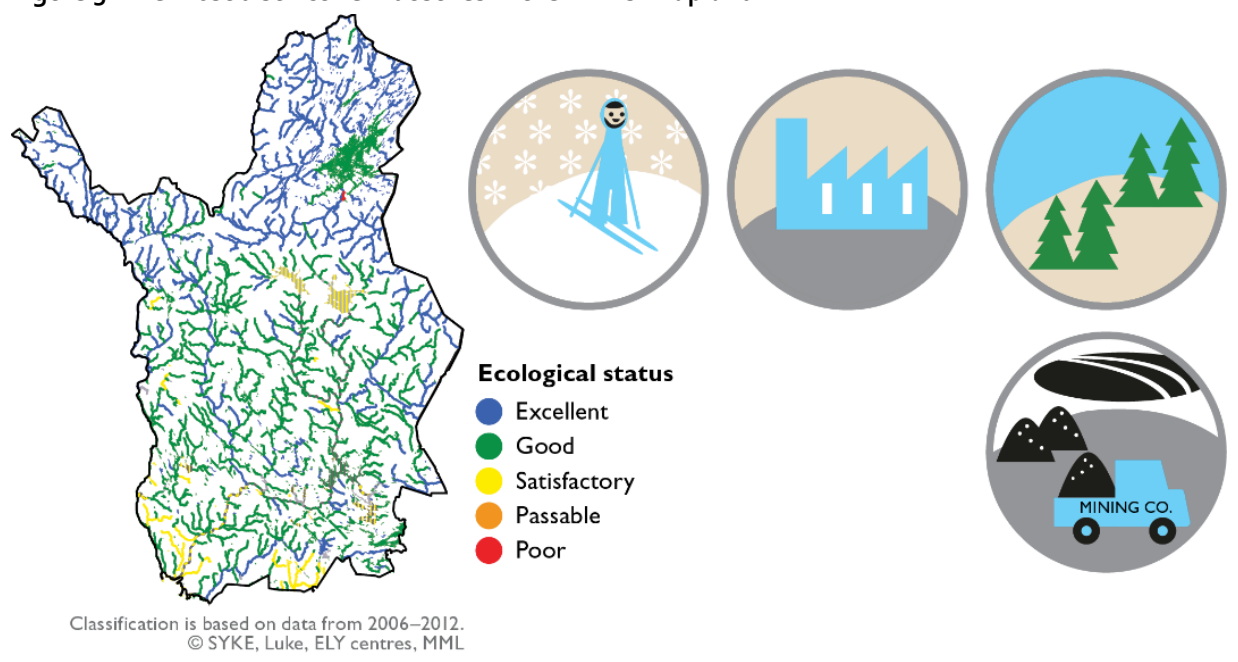

Economic and water-related data on a sample of relevant industries in the Finnish Lapland

\begin{tabular}{|l|l|l|l|l|}
\hline Industry & Employees & $\begin{array}{l}\text { Share of } \\
\text { Lapland } \\
\text { (\%) }\end{array}$ & $\begin{array}{l}\text { Water } \\
\text { intensity }\end{array}$ & $\begin{array}{l}\text { Industry-specific examples of } \\
\text { typical waste water components }\end{array}$ \\
\hline Basic iron, steel \& ferro-alloys & 2466 & 60 & Very high & Heat, metals \\
\hline Accommodation & 1380 & II & High & Nutrients \\
\hline Pulp, paper and paperboard & 1200 & 10 & Very high & Nutrients, organic carbon \\
\hline Mining of ore metals & 543 & 19 & High & Metals, sulphate \\
\hline Motor vehicles & $30 I$ & 26 & Moderate & - \\
\hline Skiing centres & $\sim 180$ & 15 & High & Nutrients, consumer chemicals \\
\hline Freshwater aquaculture & 33 & 15 & Very high & Nutrients \\
\hline All industries & 39630 & 2.6 & - & Not applicable \\
\hline
\end{tabular}

I) Percent of the industry's total revenue in Finland

Note: The most distinctive industries in the Finnish Lapland, their water intensities and examples of typical wastewater constituents. On the background map, ecological classification of the water bodies are indicated as follows: blue: excellent; green: good; yellow: satisfactory, orange: passable; red: poor. 
Overall, the majority of the industries that are strong in Lapland compared to their national total output value are highly water intensive (Salminen et al. 2018). Subsequently, this may also entail significant pressures on water quality in the region, both directly and indirectly.

Despite the large proportion of Finnish mining occurring in Lapland (19\%), mining industries' direct contribution to the GDP of Lapland was only about 3\% in 2015. Despite being classified as a high water-intensity sector, mining is not currently expected to cause water scarcity issues as the total volume used by the industry in Lapland is about 3 million cubic meters, or roughly 0.02 percent of the extent freshwater resources of the region.

Manufacture of pulp, paper and cardboard contributes about $11 \%$ to the total GDP of Lapland. The paper and pulp mills located in Lapland, more precisely in Kemi, at the mouth of the river Kemijoki, abstracts roughly o.8\% of the river's average flow. Despite its significant economic contribution and high water intensity, the industry is also not expected to cause a water scarcity issue.

An additional element is that freshwater bodies in Lapland receiving such effluents are naturally very nutrient poor. Consequently, they are prone to changes in the level of nutrients and other substances from human activities. Currently, however, manufacturing of steel, pulp and paper is concentrated in the Maritime Lapland and the effluents of these factories are discharged into the sea. Mining sector makes a specific challenge since its impacts on the quality of freshwater bodies result from the operations (process waste waters), from the waters leaching from the mining area and from the mine waste areas in operational or closed mines. The water emissions from this industry are also highly mine-specific and depend e.g. on the quality of the ore, the exposed area of the mine (open pit or underground mines) and the level of water management and water treatment technologies used. Tourism - accommodation and skiing centres - has a significant impact on water use and wastewater generation in the Finnish Lapland. In skiing centres, freshwater is used in abundance to make artificial snow for the slopes. Additionally, skiing centres and accommodation together use ca. $7 \%$ of the total mains water volume distributed by the water utilities in the Finnish Lapland. Ylivainio et al. (in prep) also measured brominated flame retardants in the sewage sludge obtained from a wastewater treatment plant receiving most of its influent from skiing centres in concentrations significantly higher than in any of the 15 other sewage sludge samples obtained from municipal waste water treatment plants located in Finland. This indicates that waste waters from skiing centres might be a significant source of consumer chemicals potentially entering the receiving water bodies. 


\subsection{Water resources and their condition in Iceland}

Water is one of the primary foundations for quality of life in Iceland. Geothermal water is used to heat homes and for various production processes, electricity is primarily generated by hydropower plants, and groundwater is used for the water supply by utilities.

Freshwater resources in Iceland are quite abundant. The total land area of Iceland is $103,000 \mathrm{~km}^{2}$, of which glaciers cover $12,000 \mathrm{~km}^{2}$ and lakes around $3,000 \mathrm{~km}^{2}$. Additionally, annual precipitation rates are high, around 1,600-1,700 mm (Björnsson et al. 2018), with precipitation more abundant in south and south-east Iceland where rates can be as high as $5,000 \mathrm{~mm}$ per annum (Icelandic Meteorological Office). Estimated annual runoff is $4,800 \mathrm{~m}^{3} / \mathrm{s}$, of which groundwater runoff is around 1,000 $\mathrm{m}^{3} / \mathrm{s}$ and glacial rivers 2,000 $\mathrm{m}^{3} / \mathrm{s}$ (Sigurðsson et al. 1992, Jónsdóttir 2008, Egilson and Stefánsdóttir 2014). Most of the rivers are of a diverse origin, including glacial, spring, and run-off sources.

The nutrient status of Icelandic waters can be naturally high due to the presence of young bedrock and extended retention times in lakes and wetland areas. An example of this is Lake Mývatn and River Laxá which base their productivity on nutrient rich groundwater in the young bedrock (Einarsson et al. 2004, Kristmannsdóttir et al. 2007). Many of the salmon rivers in the old bedrock areas base their productivity on outflow from upstream wetland areas (e.g., river Selá in Vopnafjörður), and in many cases can be defined as naturally eutrophic ecosystems.

On average pollution of Icelandic freshwaters is low, although local pressures exist and are primarily caused by inefficient sewage system, industrial activity, fish farms or tourism. The main pressure on freshwater environments is caused by hydropower production.

Groundwater is the main water source in Iceland. Total abstracted groundwater reached approximately 290 million cubic meters in 2015 (Icelandic Meteorological Office 2018). This volume was distributed along different sectors as reported in Figure 6.

On average, the use of groundwater resources is far below $1 \%$ of the annual flow. Additionally, more than half of the population lives in SW Iceland in the capital area where precipitation is high and groundwater resources are abundant. Groundwater abstraction from current sources in the capital area is about $1 / 3$ of the estimated maximum sustainable abstraction (Vatnaskil 2015). 
Figure 6: Water abstraction volumes in Iceland in 2015

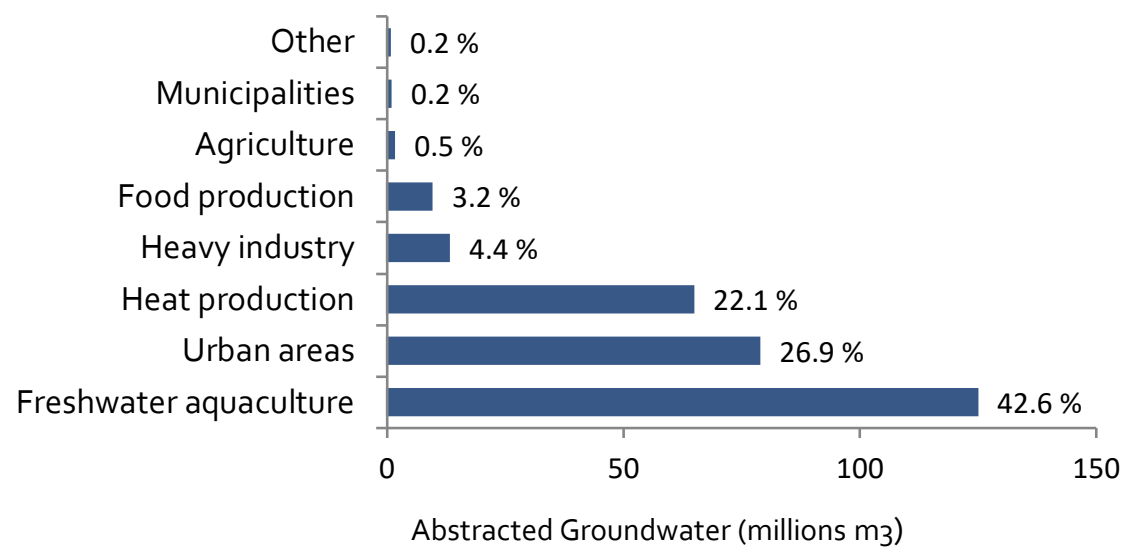

Note: Note that sectors indicated in the statistics are not fully compatible with European statistical classifications. Values represent abstraction volumes and not necessarily used volumes, particularly for domestic and agricultural applications. Percentage values are percent of total groundwater abstracted $\left(292,889,571 \mathrm{~m}^{3}\right)$.

\subsubsection{Icelandic tourism}

Many of natural spectacles in Iceland are connected to abundant clean natural waters of different types - rivers, lakes, springs and glaciers. Due Iceland's climate, geology and isolation many of these ecosystems are unique, including the warm and cold springs and naturally nutrient-rich freshwaters. The productivity of these ecosystems provides the basis for the salmon and trout stocks and exceptional bird life present in the country. An important issue for Iceland is managing these unique ecosystems under increasing environmental pressure from tourism.

Tourism in Iceland has increased drastically in the last two decades. According to information from the Icelandic Tourist Board (2018b), the number of tourists in 2017 were almost 2.2 million compared to around 303 thousand in the year 2000 and 52 thousand in 1970 (Figure 7). The length of the tourism season has also increased to nearly year round. The population of Iceland is approximately 350 thousand (Statistics Iceland 2018) and therefore the number of tourists in many areas exceed the number of inhabitants for portions of the year. This phenomenon can be extensive e.g. in remote uninhabited areas or areas with low population density. 


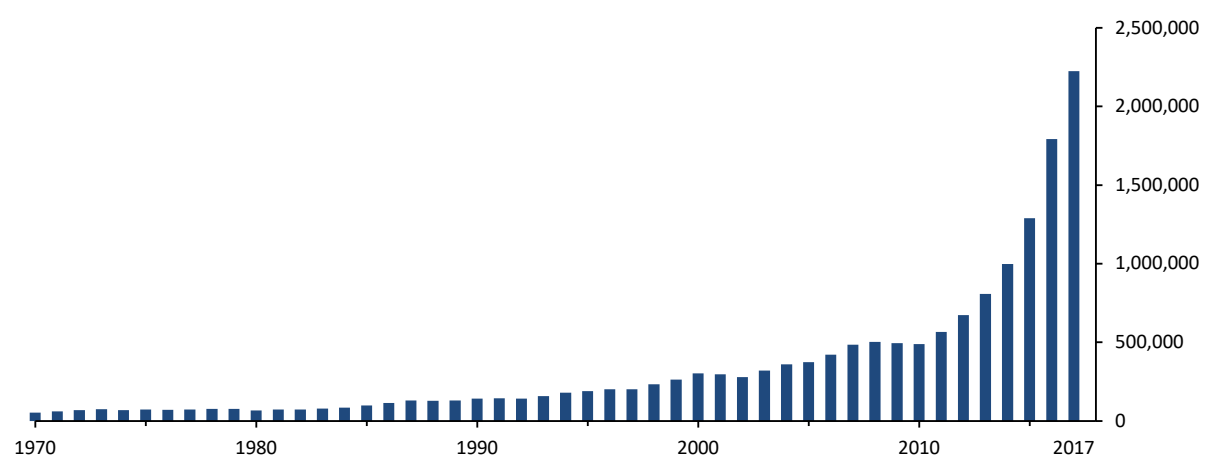

Source: Icelandic Tourist Board (2018b).

According to a survey from 2016 (Icelandic Tourist Board 2016), 83\% of the tourists mentioned nature as the main interest for visiting Iceland; most of them mentioned unspoiled and undisturbed landscape, scenery and wilderness, volcanoes and lava, glaciers and waterfalls. It is therefore important to limit the pressure on these sites and ensure sustainable usage of the environment in the long term. In fact, $79 \%$ of the surveyed tourists would agree with this sentiment; mentioning that they thought the pressure on the environment was too high. It is important to assess how sparsely populated areas can respond and adapt to the multiple pressures and challenges tourism presents. The situation in Iceland could serve as an example for other remote areas that may experience an explosion in tourism.

There are many conflicting issues connected to increased tourism that impact how effectively societies manage the balance between pressures and protection of their water resources. As mentioned in Salter et al. (2003), the Nordic Council of Ministers is aware that tourism is often an important economic driver for a community, increasing job opportunities and supporting infrastructure improvements that benefit quality of life. However, prolonged periods of tourism are required to develop and support the infrastructure of both tourism and local communities (e.g., schools, medical service and proper build-up of sewage and waste treatment systems). The infrastructure of small societies often cannot sustain the increasing load of people presented by large influxes of tourism which can lead to significant environmental and cultural stresses.

In many areas of Iceland, especially in sparsely or uninhabited areas in the highlands, there has been a logistic tendency to enlarge existing facilities to service the increasing tourism. However, the pre-existing structures were often meant to service only dozens of people a year for limited periods of time. Examples of this are the highland sites Hveravellir and Landmannalaugar (Infobox 3). There, the main points of interest are the natural geothermal baths, hot springs and unique landscape. The facilities were built very close to the geothermal sites, convenient for bathing and warming up the cottages, and sufficient for local use. These sites are now serving hundreds to thousands of people per day 
(Icelandic Tourist Board 2016). Expanding these facilities would place a heavy burden on the local environment and complicate the protection of these exceptional sites.

The emphasis in Iceland's National Planning Strategy is to support sustainable use of the highlands and minimize the impact on the environment (National Planning Agency 2014). According to the strategy, tourism infrastructure should be placed at specific locations on the main highland roads or preferably on the borders of the highlands. Additionally, Guðmundur Ingi Guðbrandsson, the Minister for the Environment and Natural Resources, has publically stressed the importance of developing tourism infrastructure outside of sites of interest (Gudbrandsson 2017). It falls to municipalities to enforce the planning strategy. However, it has been pointed out that many of the definitions and plans put forward must be more clearly defined or redefined to secure a holistic and coherent function (e.g., Icelandic Travel Association 2012).

The ideal of holistic planning in these sensitive areas has not yet been realized. At the moment, local municipalities and tourist companies are in rescue mode trying to improve the situation. This has resulted in suggested future plans that are often based on the initiative and needs of the tourist industry. The limited economic resources and strong desire for improved job opportunities also have an important influence on the final decisions of municipalities. The focus on environmental protection and water quality is unfortunately often a secondary issue despite nature being the primary point of interest.

Cultural attitudes can have an impact on development and possible solutions or lack thereof. The "Everyman's Right" is a Nordic principle of public access that is a point of some pride among the Nordic countries (Salter et al. 2003). In Iceland, this is actually one of the obstacles to environmental protection, as the community hesitates to introduce access fees for natural areas and infringe on the Everyman's Right principle. Until recently the society has hesitated to introduce human elements (e.g. construction of pathways or observation decks) into wild settings. This is gradually changing in Iceland as the tourism pressure overtaxes many unique areas.

The management of these sites is difficult for many of the municipalities in Iceland. Many inhabited areas have very low population densities and many sites have no population at all. An example is Öræfi in south-east Iceland, with high levels of tourism because of the spectacular Skaftafell and Vantajökull areas. According to Registers Iceland (2012), Öræfi has only 90 inhabitants but the number of tourists in e.g. August 2017 was 27 thousand (Ólafsson and Thorhallsdottir 2018). A connection to nature is a strong entity in the local population's wellbeing (Reynisdóttir and Jóhannesson 2016). The Öræfi community has expressed concern over the volume of tourism and emphasized the importance that environmental management takes their values and knowledge into account. Environmental management will not be successful with only governmental regulation and the need of the tourist business as a focal point.

In 2008, the first comprehensive valuation study of ecosystem services in Iceland was made for a popular recreational site in Heiðmörk, located on the edge of the Capital region. It is an important recreational site with forests, lakes, rivers and an impressive landscape; the area also serves as the main groundwater source for the Capital area. Heiðmörk is a good example of a multifunctional ecosystem providing a range of services and provides a good foundation for such a study. Importantly, the geology and 
ecology of the area is fairly well known. Multiple valuation methods were used to evaluate a variety of ecosystem services, including provisioning, regulating, cultural and amenity services (Davíðsdóttir 2010, Jóhannesdóttir 2010, Kristófersson and Eiríksdottir 2010, Sigurðardóttir and Krisofersson 2010). The Water Catchment Area was assessed with replacement cost and cash flow analysis (Sigurðardóttir and Krisofersson 2010) and the lakes with market price, defensive behaviour, travel cost and factor income (Jóhannesdóttir 2010). The total value of the ecosystem services was estimated to be 14-33 times higher than the replacement cost of the water service for the Capital area (Kristofersson 2014). The study and its results clearly demonstrate the importance of such valuation studies and the need for increased incorporation of valuation into local and national decision-making.

A recent paper by Arnason (2017), concludes that restricting access to a tourist site by charging a positive access fee is socially beneficial, given that the natural features and the enjoyment of the visit is negatively affected by the number of visits. The paper suggests a method for pricing access fees where the valuation of natural features, renewal processes and possible human impacts on the natural features are included with the tourist demand and site cost functions. The method is probably the most efficient way of protecting natural sites under extreme pressure in countries with otherwise very good environmental status. The main problems are in most cases related to a lack of knowledge of the natural environment.

Currently, access to most of Iceland's natural tourist sites remains free of charge, with a huge political debate on how to solve the increasing pressure on and poor condition of many sites. Pricing as a solution has been resisted by the public authorities (Árnason 2017 and references therein). 
Infobox 3. Landmannalaugar

Landmannalaugar is a geothermal area in the Icelandic highlands and part of the Friðland að fjallabaki [Place of retreat behind the mountains] nature reserve. The reserve was protected in 1979 and is on the UNESCO tentative list in recognition of its unique environments created by its volcanic history. One of the main attractions is the natural bathing pool that runs out from beneath the young lava field at Landmannalaugar.

Landmannalaugar is one of the most popular tourist sites in the Icelandic highlands, with an estimated 154-199 thousand visitors in 2017 (Icelandic Tourist Board 2018a). Today the tourist service and accommodation is based at the same site as a barracks (1951) and two old turf houses (180os, 1927) built to serve as shelters for shepherds and inland travelers. In 1969, the Travel Association built a new house at the site that has accommodation for 78 persons. These service facilities and nearby camping sites are quite close to the natural pool (125-250 $\mathrm{m}$ ) (Figure 8 ). The proximity was logical when there were very few visitors, but today it is focusing environmental pressure on the area. In fact, the site is on the red alarm list from the Environment Agency of Iceland, indicating an area in danger of losing its protection value or having already lost it partially (Environmental Agency Iceland 2018). It is clear that the pressure has vastly increased in the last few decades and yet the facilities today are based on the same locations as almost 70 years ago.

In 2017 the local municipality put forward a detailed land use plan to the Planning Agency. The plan includes improved on-site infrastructure, relocated on-site parking $150 \mathrm{~m}$ further from the site, relocated on-site camping to an alternate location $1.5 \mathrm{~km}$ away that will also include expanded service and accommodation facilities. The conclusion of the Planning Agency was to request an environmental impact assessment e.g. because of the increased site footprint and possible related hazards (National Planning Agency 2018).

Figure 8: Landmannalaugar is one of the most popular tourist sites in the Icelandic highlands

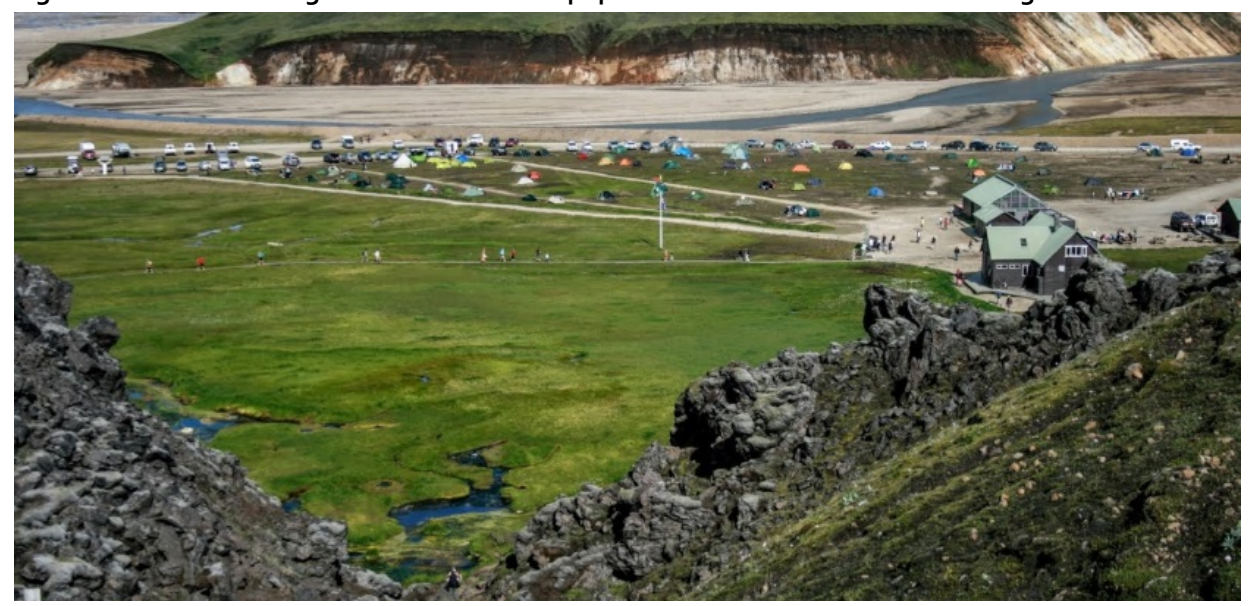

Note: Geothermal groundwater (lower left) runs from beneath the lava field and feeds the bathing pool (left, out of frame); the tourist service facilities and camping site sprawl in the background. Photo by Gerður Stefánsdóttir. 


\subsection{Hydropower in Finland and Iceland}

In the Arctic, there is generally a high potential for hydropower production. The weather conditions, high quantity runoff water, stable base flow of groundwater discharge compared to surface water and water storage capacity in snow and glaciers are important elements supporting efficient hydropower production in the region. In 2017, hydropower stations in Iceland produced 12.9 TWh, supplying $73.1 \%$ of the country's electricity demand. (Hjaltason et al. 2018). The remainder is supplied by geothermal (26.9\%) or fossil fuel (0.04\%) power generation. According to the National Energy Authority, it is estimated that only around $20 \%$ of the available hydropower capacity in Iceland is already in use (National Energy Authority 2018). At the same time, international demand for renewable energy sources like hydropower is increasing. This could attract further investments in hydroelectric power stations to the Arctic.

In Finland, hydroelectric power generation covers $10 \%$ to $25 \%$ of the total production of electricity. In 2016, the total hydroelectric power generation was 15.6 TWh in Finland, comprising $23.6 \%$ of the total electricity production. In Lapland, there are 13 mid-size or large hydroelectric power generation plants. Together they produce about $35 \%$ to $40 \%$ of the country's hydroelectric power. Even though hydroelectric power generation is a renewable source of energy, it has adverse impacts on aquatic ecosystems (Leskinen et al. 2014). It can also have broad effects on local hydrology including impacts on groundwater levels and discharge (Egilson 2016).

In Iceland, the main hydropower stations use glacial rivers as a water source. Although most Icelandic rivers have a combination of source inputs and often base their stability on the groundwater sources, this usage does not affect water abstraction for other human uses because glacial rivers are not suitable for commercial use and demand for groundwater at these sites is otherwise low. Glacial rivers are generally large, with high annual variability in discharge, high amount of suspended sediments and periodical extreme events like jökulhlaups (outburst flood) (Jensen et al. 2018, Hardardóttir and Zophoníasson In press). Discharge and sediment transport rates peak in the summer and experience high daily variability. A good example of high sediment transport and variability is the Skaftá River. It transports an average of 5.5 million tons of suspended sediment annually, but during the jökulhlaup of October 2015, sediment transport was estimated to be 8.6-17.1 million tons (Jensen et al. 2018). These characteristics have historically made glacial rivers very difficult to cross, isolating some inhabited areas. In many aspects the glacial rivers are seen as dangerous and without ecological importance; therefore not worth protecting (Icelandic Institute of Natural history 2017). On the other hand, these rivers are quite unique and an important part of the Arctic landscape. The sediments carried by the glacial rivers have an impact on local land formation and nutrient transport to the marine environment (Eiríksdóttir 2016).

In the near future it is to be expectant that increased social end economical demands will vastly increase the hydropower buildup in the North. It is important to understand this prospect from multiple perspectives and how hydropower development will influence the ecological services in the Arctic. 


\title{
3. How can freshwater natural accounting be used in governing Arctic freshwater resources?
}

\author{
Marcus Carson, Virpi Lehtoranta, Tea Nõmmann, Gerđur Stefánsdóttir and Sari Väisänen
}

One crucial challenge for employing Natural Capital Accounting (NCA) to support governing Arctic freshwater resources is ensuring a good fit with the ways regulatory and management efforts are organized. It is important that the knowledge summarized in the accounts corresponds with the institutional arrangements for governance and management of these resources. For example, it is essential that knowledge is structured to be informative at the scale at which governance and management activities are carried out, whether at the national, regional or local levels. It is also essential that it meshes with different types of policy and management roles and activities: policymaking, implementation, management, and monitoring and assessment. In addition to ensuring that the knowledge needs regarding both water quality and economic consequences of likely options are filled, potential users of the accounts must have the competencies needed to understand and utilize the knowledge contained in the accounts. With these challenges in mind, this chapter reviews institutions that are part of governing and managing Arctic freshwater resources. It then focuses on one especially important set of institutional arrangements, the European Union Water Framework Directive (WFD).

A surprisingly dense array of different institutional arrangements regulate human activities and seek to balance key trade-offs related to Arctic freshwater resources, and they do so in a variety of ways. These different policies provide an institutional framework for regulating and managing activities that impact the condition of freshwater resources in the Arctic and elsewhere. Because these institutions apply to different forms of freshwater and the ecosystem services they provide, they differ in substantive focus (i.e., water quality, biodiversity, etc.); involve a wide range of sometimes overlapping goals, interests and social actors (often in support of emphasizing conservation versus use); and operate at multiple levels or scales (Hollingsworth et al. 2002, Bache and Flinders 2004, Ostrom and Janssen 2005, Keskitalo and Pettersson 2012). Institutions also require different types of metrics to assess trade-offs and monitor status on an ongoing basis. These various forms of regulation provide a dense web of interrelated goals and requirements for protection. Yet, their effectiveness and success are heavily influenced by one another, through the degree of coherence among these goals (Nilsson et al. 2012), strong coordination across levels or scales (Söderberg 2016), and ultimately upon effective participation by 
and cooperation among the societal actors charged with implementing the protective regulations in local contexts (Blackstock and Carter 2007). The challenges of this complexity include:

- A high degree of complexity across institutional arrangements aimed at protecting water quality, or protecting people or ecosystems affected by poor water quality;

- Successes and shortcomings may be measured in ways that are incommensurable -i.e. not comparable on the same terms;

- Expectations or requirements for involvement/participation of diverse actors differ, with a general trend toward greater public involvement;

- The need for composite metrics that provide essential feedback on the effects of policy choices and other change trends, and that are also meaningful and useable for non-specialists.

The broader institutional and organizational challenges of coordination and coherence are highlighted in Figure 9 below, which identifies the diverse forms of regulatory institutions established to deal with environmental challenges, and the multiple types of interrelated issues to which they are addressed. It is in this broader context that the WFD must be implemented. To do so effectively, it needs to "reconcile several wide-ranging topics: the vertical integration of governance across geopolitical levels, the horizontal integration across the many types of stakeholders, the chain of activities leading to pressures and impacts, the risk assessment and response (as risk management) to those impacts, the creation of ecosystem services with a potential to deliver societal benefits, and the Ecosystem Approach" (Boyes and Elliott 2014:p 40, c.f. Elliott 2014). 
Figure 9: Organizational "horrendegram" - environmental regulatory institutions and issues

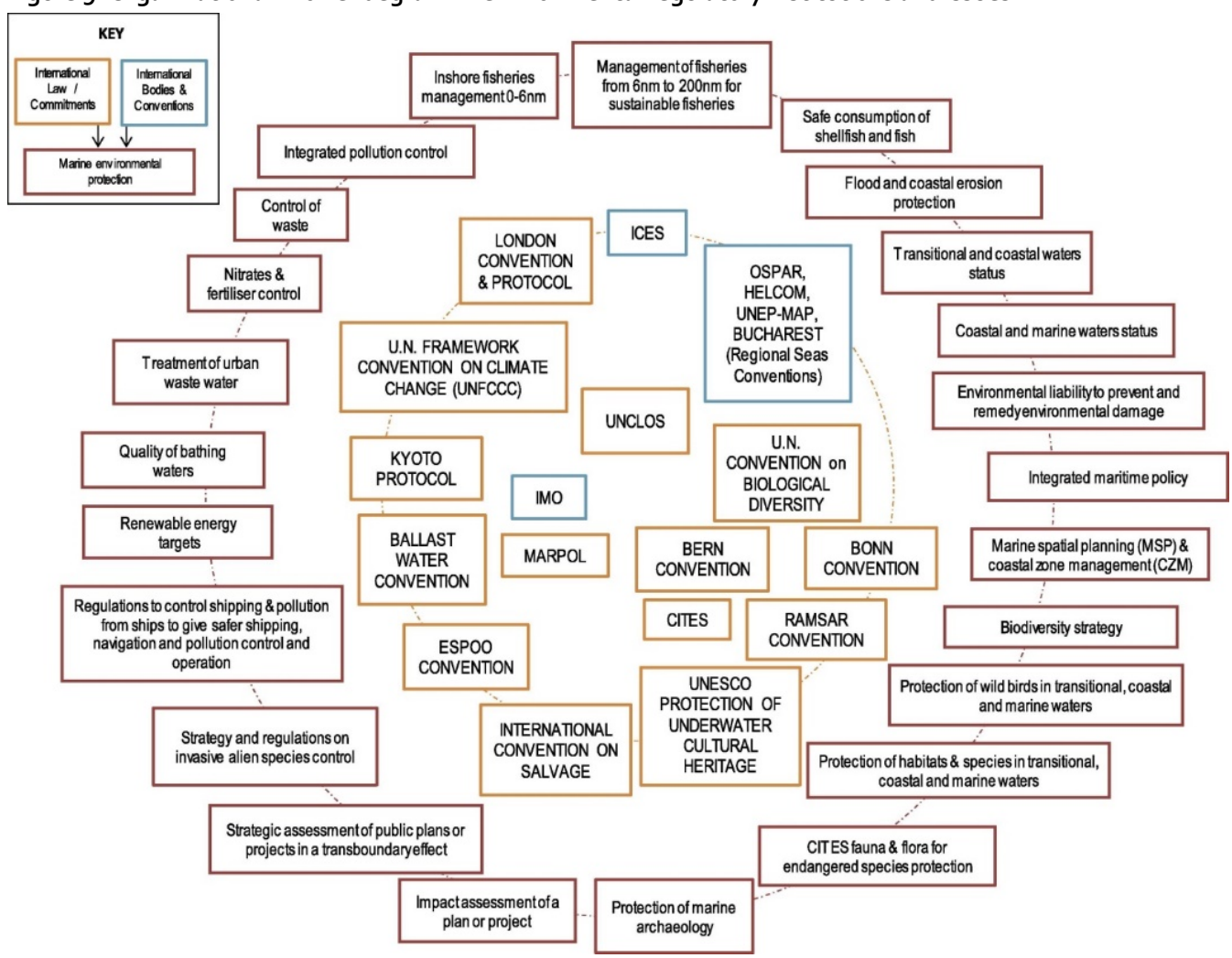

Note: Reproduced from Boyes and Elliot (2014).

Although the regulatory regimes of the Nordic countries do differ, strong commonalities are rooted in regional-cultural similarities of the Nordic countries and in a long history of Nordic cooperation. In addition, many of the regulations originate with international agreements or Directives of the European Union. While Sweden, Denmark and Finland are all members of the European Union and Norway and Iceland are not, the latter in many instances also implement EU Directives by virtue of their membership in the European Economic Area and other relevant arrangements (Hojem 2015). Several measures adopted by the EU provide protection for freshwater resources. Key among them are the Water Framework Directive (Directive 2000/60/EC), the Habitats Directive (Directive 92/43/EEC), and the Birds Directive (Directive 2009/147/EC). The WFD has arguably the most far reaching impacts and to some extent overlaps the other measures.

At a general level, institutional arrangements intended to protect people and/or ecosystems typically provide a conceptual framework for defining the nature of a problem or challenge, the kinds of responses considered appropriate, and what goals are to be achieved. They also indicate types of expertise considered legitimate for providing knowledge about the problem, identify what interests should participate or be consulted in relevant processes, and specify methods and metrics for providing 
accounts such as ecological status (Burns and Flam 1987, Carson et al. 2009). Methods and metrics are of particular interest in this report.

In addition, implementation of such programs inevitably plays out in a particular context(s) in which environmental, as well as institutional, economic and other social factors interact to influence eventual implementation and other developments. Because the broader web of institutional arrangements that apply to freshwater resources is quite extensive, this context has shaped WFD implementation in the Nordic countries. Some of these other regulatory institutions focus on biological diversity, such as the Ramsar Convention or the Convention on Biological Diversity, with emphasis on species richness and their relationship to freshwater ecosystems. Yet others focus on evaluating and regulating planned human activities with potentially damaging impacts on water quality and other ecosystems characteristics (typically requiring some form of Environmental Impact Assessment (Emmelin 1998a, b). These include activities such as mining, agriculture and forestry, energy production (hydropower), transport and tourism.

Given that human activities have often resulted in a damaged or diminished status for freshwater resources, a central goal of the WFD has been to restore water resources to a "good" ecological and chemical quality status (Kallis and Butler 2001). Determining and managing acceptable trade-offs is a key challenge. Ecosystem services enjoyed by some interests undermine those available to others in the short term, while overuse of some ecosystem services may undermine others needed for longer-term protection of biodiversity, nutrient cycling, etc.

The Ramsar website notes that "recognition of the diverse values of wetlands is essential to their wise use" (Kumar et al. 2017). Yet, as suggested above, the task that is perhaps most challenging for the various types of regulatory efforts is that they seek to balance and manage a variety of different uses and trade-offs that are not easily comparable. While managing the trade-offs between use and conservation to ensure healthy ecosystems is a starting point, determining bases for adjudicating between the different kinds of use and activities impacting ecosystems is also a crucial part of this task. For example, Sarkki et al. (2015) observe the fact that the European Arctic is rich with hydrocarbons, minerals, forest resources and more. In practical terms this means that land use decisions that may affect freshwater resources are also likely to impinge on activities such as tourism or reindeer herding, and are likely to be made more complex by the intersection of local, national and international interests. These kinds of trade-offs can be difficult, even where deliberate steering is effective. In such instances, regulations that place a high priority on protection of freshwater resources may well be decisive. 


\subsection{Water Framework Directive (WFD)}

The core goal of the WFD is to improve and protect the status of freshwater resources across the EU, including the European Arctic. The WFD has been characterized as "one of the most important and most ambitious pieces of legislation in the history of the EU's environmental policy" (Bourblanc et al. 2013:p 1449). It established requirements for an overall governance and management structure and procedures, including reporting requirements and deadlines, that are intended to substantially improve water quality within the EU (Chave 2001). As a framework directive, it also offers Member States considerable flexibility in setting objectives and national-level institutional arrangements for pursuing those objectives. The WFD constitutes what can be characterized as a paradigm shift in its reconceptualization of water quality problems by moving toward a systemic approach to tackling environmental degradation and protection, perhaps most notably by organizing action by river basin rather than political boundaries (Bourblanc et al. 2013).

Here, as elsewhere, collaboration between the Nordic countries in their implementation of the WFD includes considerable investment in learning from one another through sharing ideas and practices. An informative and succinct overview of the water status, implementation actions and plans of Iceland, Norway, Sweden and Finland based on Nordic collaboration is available (Halleraker et al. 2013). This collaboration is especially important partly as a function of shared watersheds, where greater crossborder cooperation is needed, and where comparability of indicators is critical to the success of the efforts. Identifying and refining ways of effectively supporting participation by the public and other types of stakeholders is also key, both as a means for properly engaging similar groups of stakeholders, and for managing shared watersheds.

Following the institutional logic outlined at the beginning of this chapter, the WFD identifies poor water quality as its central problem and requires Member States to conduct a number of different planning and assessment actions to achieve the goal of good water status. Following the Directive, the countries involved are required to develop implementation plans referred to as a "Programme of Measures". Beginning in 2001, the European Commission has supported an informal effort called the Common Implementation Strategy, through which EU Member States' agencies responsible for water and environmental protection have worked with other stakeholders to address commonly experienced challenges encountered in implementing the Directive. Such challenges include measurement and assessment of ecological status, chemical and other pollution, and sharing practical experience in translating the framework into practical actions (Keto et al. 2014).

\subsubsection{Data on ecological and chemical status}

Clearly, effective implementation of the WFD requires good monitoring data, and properly balancing use with conservation requires good knowledge of both ecological status and of the economic and other social consequences of those choices over both short and long time horizons. Accounts that integrate these types of data (as described 
in chapters 1 and 4 ) in a systematic and rigorous manner can be expected to provide critical support for both decision making and monitoring.

As part of implementing the Directive, Member States gather ecological, hydro-morphological and chemical data for the WFD classification of the state of the water bodies. In Sweden, this information is kept in an online database that is publicly accessible (Water Information System Sweden - http://viss.lanstryrelsen.se).

The VISS database includes assessment of the ecological, quantitative and chemical statuses, along with the underlying assessments on elements such as fish and acidification. The database is also being developed include information on environmental monitoring, quality standards, and measures intended to improve water quality. The data draws upon existing monitoring, however, the breadth of which was a point of concern in the most recent European Commission evaluation of Sweden's WFD implementation. In another example, Finland does WFD classification only every six years. This means that it is not yet possible to make trend assessments from this data. As this data is very detailed and water body-specific, it is also not possible to use it directly in national accounting. However, the European Environment Agency gathers environmental data for its State of the Environment reporting, and this is done annually for a smaller but still relevant group of parameters for lakes, rivers and groundwater. This information is collected on an annual basis, and from about 200 lake/river/groundwater observation points in Finland, for example. Thus, the data delivered to the European Environmental Agency is very similar to the WFD data and enables better trend analyses than the WFD data reported in every six years. ${ }^{1}$

The WISE WFD database contains data from the 1st and 2nd River Basin Management Plans reported by EU Members States. The database includes information about surface water bodies (number and size, water body category, ecological status or potential, chemical status, significant pressures and impacts) and about groundwater bodies (number and size, quantitative status, chemical status, significant pressures and impacts). The information is presented by country, river basin district (RBD) and river basin district sub-units (where applicable, see www.EEA.Europa.fi). From the demand side of future water accounts, reporting of WFD would benefit from raw data for water abstraction at a water body level, at least in Finland. ${ }^{2}$

\subsection{Managing human activities in complex, multi-level systems: scale and role}

Two of the key dimensions where the fit between knowledge and governance activities are especially important are 1) geographic scale, and 2) the specific roles played by participants. Institutional arrangements that affect freshwater resources are organized at scales that range from global to regional to local, just as ecosystems characteristics

\footnotetext{
${ }^{1}$ Mitikka, Sari, Finnish Environment Institute, interview 27 September 2018.

2 Järvenpää, Lasse, Finnish Environment Institute, interview 20 September 2018.
} 
often differ at different geographic scales. A focus on the distribution of WFD authority and responsibility within the Nordic countries offers the opportunity to examine key elements of the decision/management apparatus expected to ensure that freshwater resources in these Arctic countries are protected and where needed, improved.

Here we can distinguish several different kinds of responsibility: authority for decision-making; policy input and consultation; responsibility for implementation of decisions made, monitoring and feedback to decision makers and managers; and finally, enforcement. These responsibilities are distributed differently across national, regional and local scales. It is the societal actors who carry these different responsibilities who must make use of the diverse types of monitoring and other data to the extent that they are available, including natural capital accounts. However, the differences in roles suggest that the capacity to use such accounts is likely to vary, as is the particular way they are employed for guiding action.

The specific structures for decision-making, implementation and management varies somewhat between the Nordic countries. This is partly due to institutional differences that preceded the WFD and partly due to particular differences in circumstances and preferences. Nevertheless, Figure 10, which describes the distribution of responsibility in Norway, illustrates a basic common logic.

Figure 10: Organizational structure of Norwegian WFD implementation

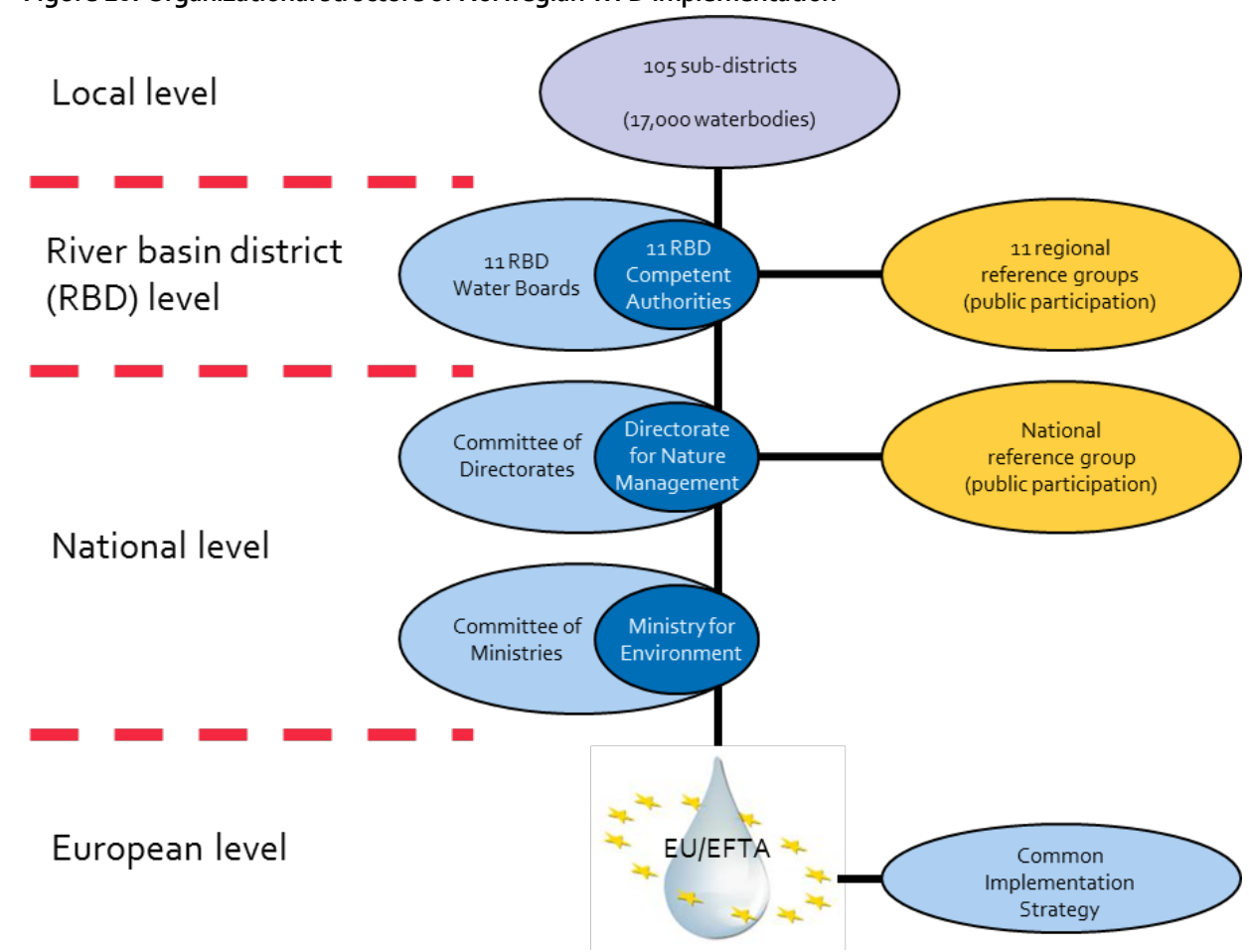

Source: Adapted from Halleraker et al. 2013. 
We can see that with transposition of the WFD at the national level through the parliamentary adoption of the necessary legislation, decision-making authority is delegated to relevant ministries and national-level implementation responsibility is delegated to multiple agencies or directorates. The exact combination of ministries varies; in each case the Environment Ministry has a lead role. For example, in the Norway example below, that lead role is shared by a "Committee of Ministries" chaired by the Ministry of Environment. In Finland, the Ministry of Environment steers in consultation with the Ministry of Agriculture and Forestry (Halleraker et al. 2013).

Also at the national level, a number of different governmental authorities share responsibility for implementation. In Sweden, the Swedish Agency for Marine and Water Management bears the lead responsibility with the Swedish Geological Survey, while other authorities such as Sweden's Environmental Protection Agency are also involved. In Iceland, the Environment Agency leads implementation efforts in collaboration with five other agencies/institutes, including the Icelandic Meteorological Institute, the Institute of Freshwater Fisheries; National Energy Authority; Institute of Natural History and Marine Research Institute (Halleraker et al. 2013). In Norway, national level responsibility is shared by the Ministries of Environment and of Energy and Petroleum. As illustrated in Table 2 below, the differences in lead responsibility in the respective countries illustrate the social, economic and policy intersections at which key social and economic priorities connected with water are to be managed environment, renewable energy, agriculture, and natural resources - and highlight where essential priorities must be balanced.

Table 2: Organization of WFD in the Nordic Countries

\begin{tabular}{|c|c|c|c|c|}
\hline & $\begin{array}{l}\text { RBDs } \\
\text { Nat. (IRB) }\end{array}$ & Organisation structures & $\begin{array}{l}\text { WFD coordination } \\
\text { National Level }\end{array}$ & Regional level \\
\hline Finland & $8(2)$ & $\begin{array}{l}\text { Ministry group } \\
\text { National coordination group } \\
\text { Steering groups and working } \\
\text { groups of RBDs } \\
\text { Cooperation and subgroup(s) in } \\
\text { each ELY-centre }\end{array}$ & $\begin{array}{l}\text { Ministry of Environment and } \\
\text { SYKE }\end{array}$ & $\begin{array}{l}\text { RBD Coordination: } \\
\text { Competent ELY-centres } \\
\text { Regional coordination: } \\
\text { ELY-centres }\end{array}$ \\
\hline Sweden & $5(3)$ & $\begin{array}{l}\text { Water Board (Vattendelegation) } \\
\text { The Competent Authorities } \\
\text { (Vattenmyndigheterna) }\end{array}$ & $\begin{array}{l}\text { Swedish Agency for Marine } \\
\text { and Water Management } \\
\text { Swedish Geological Survey }\end{array}$ & $\begin{array}{l}\text { The Competent Authorities } \\
\text { (Vattenmyndigheterna) } \\
\text { County Administrative } \\
\text { Board (Länsstyrelserna) }\end{array}$ \\
\hline Norway & $11(6)$ & $\begin{array}{l}\text { Ministry group } \\
\text { Directorate group } \\
\text { County level - FK/FM/VRU } \\
\text { Local project leaders }\end{array}$ & $\begin{array}{l}\text { Ministries of Environment \& } \\
\text { Energy and Petroleum } \\
\text { DN }\end{array}$ & FK (County governor) \\
\hline Iceland & $4(0)$ & $\begin{array}{l}\text { Similar to Norway but except } \\
\text { county level }\end{array}$ & $\begin{array}{l}\text { Environment Agency of } \\
\text { Iceland }\end{array}$ & $\begin{array}{l}\text { Environment Agency of } \\
\text { Iceland }\end{array}$ \\
\hline
\end{tabular}

Source: Adapted from Halleraker et al. 2013. 
Finally, each country utilizes some type of reference group structure to facilitate participation from interested peak organizations with a national perspective. These organizations have no formal decision authority or responsibility for implementation, but exert influence based on particular forms of expertise and representation of important interests. Two observations are especially relevant for national-scale engagement. First, the kinds of data needed for each of these roles - decision-making, implementation and interest representation and input, can be quite different. Balancing trade-offs between different societal goals and interests will be most tangible in decision-making and interest representation. Implementation and management, on the other hand, requires data that provides feedback on whether actions being taken are consistent with decided-upon goals and intended trade-offs.

The regional scale is defined by river basin districts (RBD). Here the geographic organizing principle shifts from political boundaries to ecosystem boundaries in the form of river basins. In practical terms, this means that governance arrangements based on previous politically-defined boundaries have had to be adapted to different boundaries defined in terms of river basins. This, in turn, has required new administrative structures and more intensive collaboration between existing ones. Some of these river basins stretch across national borders between Finland, Sweden and Norway, and many more either extend across or encompass multiple county or in-country regional boundaries for which governance arrangements already existed. Finland is divided into 8 RBDs, with 3 in the Arctic; one shared with Norway and Sweden, and one with Norway. Sweden is divided into 5 RBDs, one of which is located in the Arctic and shared with Finland and Norway. Norway encompasses 16 different RBDs, with 4 located in the Arctic, all shared with either Sweden, Finland, or both. Iceland differs due to its size and geography, with its single river basin district divided into four sub-districts.

At this regional scale of RBDs, the competent authority - the entity charged with taking action to implement the WFD at the river basin level - also differs among the countries. In Finland, the key responsibility at the RBD level is carried by Centres for Economic Development, Transport and the Environment (ELY Centres). The respective ELY Centres organize cooperation in each of the RBDs and interact with subgroups specialized on the basis of river sub-systems or field of operation (Halleraker et al. 2013). In Sweden, already existing governance institutions bear this responsibility. In this instance, county governments in five regions have been assigned as "Water Authorities" (Swedish Water Authority 2018), with administrative responsibility for their respective river basins. Each of these water authorities has a secretariat and they are responsible for cross-scale cooperation with national agencies, their respective regional reference groups, local municipalities and organizations within their districts, as well as coordinating with and learning from one another. The decision-making body associated with each water authority is a "Water Delegation" made up of a combination of political, industry and interest groups representatives and experts appointed by the government for 3-year terms (Swedish Water Authority 2018). The water delegations are charged with deciding on standards to be achieved, approving work plans and monitoring. 
While there are differences among the Nordic countries in exactly how the organization structures are set up, the complexities of the organizational structures, of managing participation, and of monitoring outcomes can be considered a challenge they all share. Table 3 illustrates the division of responsibilities and roles in the Swedish implementation of the WFD.

Table 3: Distribution of responsibilities in Sweden's WFD implementation (Swedish Water Authority 2018)

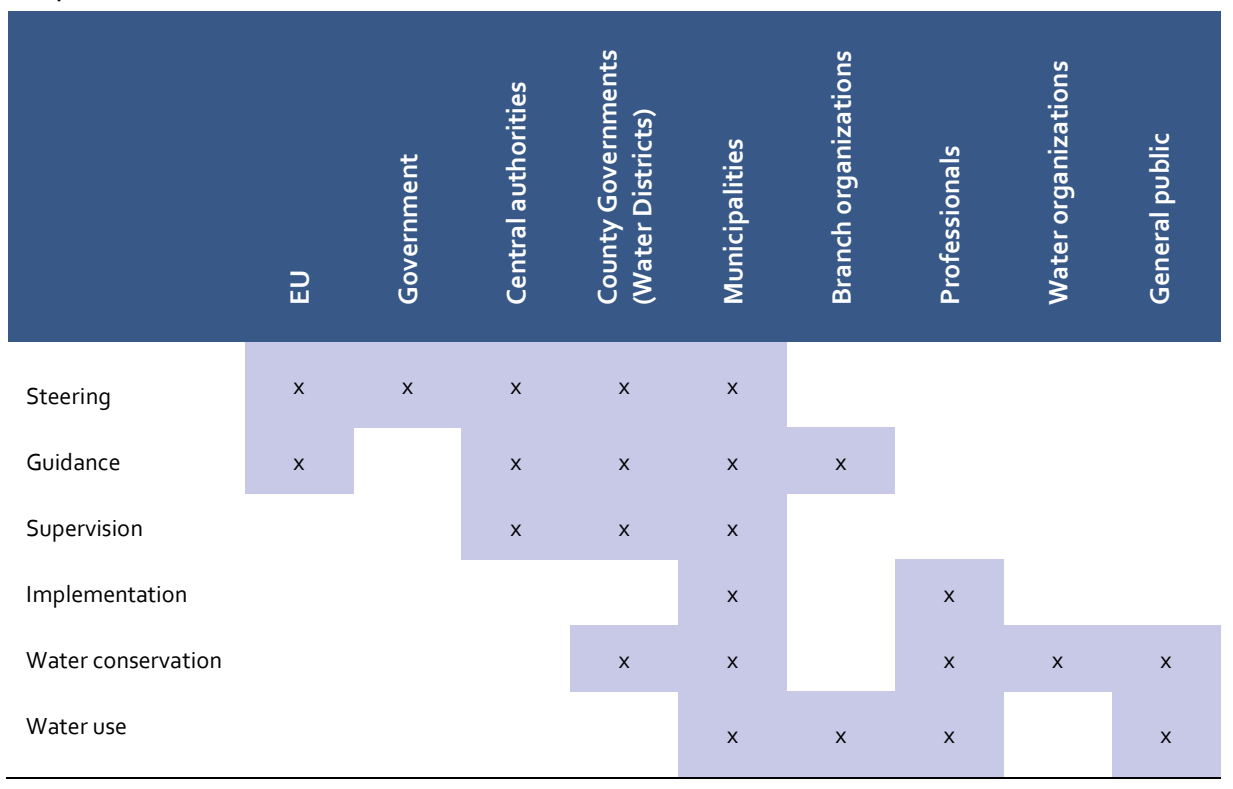

These insights point to a process of implementation - and of indicators and accounts development - that will evolve over time as needs are better defined and as data collection challenges are managed. What we find is that this policy/institutional evolution is influenced by a combination of conditions that differs among the countries in terms of economic activity, ecosystems types, institutional and cultural history, and relation to the EU. This means that in practice, the ways in which the WFD is institutionalized in each of the Nordic countries will differ to some extent, even with the high level of collaboration and sharing of experience that is often enjoyed among the Nordic countries. An important part of these differences is the way in which the WFD in each country is organized to utilize the available knowledge, and the degree to which integrated knowledge such as freshwater natural capital accounts is available for use.

\subsection{Challenges and opportunities in the WFD institutional context}

As is the case with all institutional arrangements, the organizational structure of the WFD and its implementation is very important. Yet, it is also a moving target, with some elements working better than others, and with gaps that emerge over time. A number of analyses highlight difficulties and opportunities relevant to the use of natural capital 
accounts in planning and management via the WFD. Some of these are connected with the more general challenges of implementation and building up the organizational capacity to engage important stakeholders, plan, set standards and develop policy. Others are more specifically focused on the kinds of data and decision support tools available for setting standards and balancing sometimes competing priorities.

For example, the European Commission evaluates performance of individual countries' implementation of the WFD on a regular basis. In its 2012 evaluation of Sweden's early WFD implementation, it noted that monitoring programs Sweden employed for its first River Basin Management Plans were primarily based on programs that had previously been in place. Since the starting point for implementation of new measures is the practices already in place, this kind of institutional inertia is likely to be a feature in all of the Nordic countries, with the differences in institutional histories producing different kinds of implementation challenges. The most significant challenges are associated with what have been characterized as the two principal innovative approaches with the WFD in 1) its ecosystems approach, and 2) its requirements for public participation. We have already noted how the ecosystems-based approach provides a different kind of organizing logic than previous efforts to protect and manage water resources. In addition to shifting from the previous politically defined boundaries to ecosystem defined boundaries based on the river basin, the "WFD links together a huge number of heterogeneous elements, i.e., natural, technical, and social objects, embodied in knowledge, norms, and instruments" (Steyaert and Ollivier 2007:p 33). These disparate elements represent significant challenges for developing data sources that are suitable for making initial assessments and for monitoring how well the chosen courses of action are meeting agreed upon goals. Equally importantly, data tools developed for measuring diverse phenomena (water quality, human well-being, or measuring the draw on limited resources) may be largely incommensurable - not comparable in conventional terms and therefore offer weak bases for weighing and prioritizing among competing priorities. This is one of the key areas where natural capital accounts seek to integrate diverse information to make the process of weighing alternatives a more systematic process.

Among the more systemic challenges are "vertical" integration of policy and of data across different geographic scales, and integration "horizontally" across the diverse issues and interests relevant in any given geographical area (Boyes and Elliott 2014). Use of an ecosystem-based approach speaks to some of the vertical scale issues by improving coherence across scales based on the ecosystem boundaries, defined in terms of the river basin. Yet other features, including population centres and the nature and levels of economic activities (such as agriculture or hydropower), are likely to be organized around a social and political rather than ecosystem logic. These are of course some of the challenges that natural capital accounts seek to bridge - at least in terms of integrating different types of knowledge.

The requirement for expanded public participation highlights the "growing awareness that collaborative approaches are needed because of increased complexity in water resources use resulting from increased competition, dissatisfaction with leaving important policy decisions in the hands of agency experts, and scepticism about the ability of legalistic agencies to craft viable and long-term solutions" (Steyaert and Ollivier 
2007:p 23). Consistent with this logic, one interesting observation made about water management in Sweden, for example, is that it has shifted from a largely expert-driven process to embracing the participatory process as a way of creating a forum for working out differences and developing consensus (Blackstock and Carter 2007). However, achieving sufficient participation has proven to be one of the continuing challenges due to time demands, expertise, organizational capacity and priorities within civil society (Eckerberg et al. 2012).

Broader participation also carries with it knowledge and data challenges. To the extent that increased engagement and participation from diverse societal interests is achieved, it entails participants who through their interest in particular aspects of water resources, are likely to relate more intuitively to some kinds of data - representing natural, social, technical characteristics of water resources - than to others. Conservation groups and environmental organizations are likely to emphasize water quality and ecosystem health, while some industry groups might be more concerned with water availability for economic production purposes, and municipalities concerned about availability of water resources that are sufficient and safe for household uses. The kinds of data with which the various stakeholders are familiar and conversant are likely to be that which is most closely linked to their particular concerns. In addition to difficulties created by the uneven availability of important data, the capacity of the various stakeholder groups to understand and glean insights from the different types of data is also likely to be uneven. Natural capital accounts may help address the incommensurability of environmental and economic data, but for this to be useful, stakeholders need to have sufficiently good understanding of the accounts to use them effectively.

Using another example from Arctic Sweden's Arctic region, the Bothnian Bay water district noted in its 2016-2021 river basin management plan that since the legally mandated primary goal of the programme of measures is to achieve good water quality status, there might be "positive externalities to nature tourism, outdoor life, job opportunities and rural development" (Swedish Water Authority of the Bothnian Bay Water District 2016:p 41). Yet it was also alert to potential trade-offs where other sectors might be impacted, but that the district had not had the capacity to study and estimate the possible economic value of such improvements. It instead carried out a cost-benefit assessment based on an example scenario and actual administrative costs, providing some kind of projections, but based on only one possible set of future developments. Such limitations regarding data and integration of data clearly make the balancing of interests, goals and trade-offs a much more random process than desired.

Earlier in this chapter, we identified several distinct kinds of responsibility in the governance and management of freshwater resources in the European Arctic under the institutional arrangements established by the WFD. These included policy input and consultation; decision-making authority; implementation responsibility; monitoring and feedback; and enforcement. Of these, the type of knowledge that can be integrated in natural capital accounts is most directly important for the first two. For policy input and consultation, the process of making different kinds of phenomena understandable in more easily comparable terms could facilitate the process of consensus building in participatory fora. The obvious challenge that comes with the challenges of generating a 
high level of participation is that using and understanding these accounts requires a measure of expertise, which is likely to require some consistency of engagement among participants - a clear challenge with people who engage on a volunteer basis. For people engaged in decision-making, natural capital accounts might offer the kind of economics-related knowledge noted as very limited in the Bothnian Bay district a condition likely to be similar with other competent authorities. Such knowledge could make the process of balancing trade-offs more deliberate and transparent, especially if it facilitates more informed input and consultation. Finally, in a context where the desired level of participation from civil society is difficult to achieve, the accounts may offer a sort of proxy where important public input is lacking by highlighting estimated trade-offs and benefits and enabling deliberations about them to be based on better grounded knowledge.

\subsection{Economic valuation and disproportionate costs}

By following strict rules of the WFD the Members States (MS) of the European Union may reduce or delay environmental aims of achieving good ecological status by 2021 or the latest by 2027. In order to do so, the Member States need to show that the costs are disproportionate compared to the benefits of additional measures aimed to improve the status of freshwaters applying for the exemptions. In addition, with benefit data it is possible to estimate social acceptance of the WFD. Furthermore, prioritizing of the measures and financing opportunities in general may profit from benefit-cost ratios estimated for a specific sub-river basin district.

Several WFD related valuation studies have been carried out in the Nordic countries (see e.g., Kataria 2009, Vesterinen et al. 2010, Jorgensen et al. 2013, Artell 2014, Hasselstrom and Hakansson 2014, Soderberg and Barton 2014). However, and as noted previously in Barton et al. (2012a), there remains a need for new and high quality valuation studies for several types of single ecosystem services in the Nordic countries. To illustrate how this can work in practice, we demonstrate the usage of an environmental valuation method in the WFD context (Lehtoranta et al. unpublished). The contingent valuation method was applied to estimate the economic benefits of additional water management measures for 420,000 adult residents, and for 31,000 non-residents owning a leisure time home in the River Basin Management District of Vuoksi in Finland (Figure 11).

A survey questionnaire was randomly sent to 1,512 residents and 1,000 non-residents owning a cottage in the Vuoksi river basin district. The data consisted of 780 responses: 333 from residents and 424 from non-residential cottage owners, giving response rates of $22 \%$ and $42 \%$, respectively. Information about freshwater status and management was given in the form of texts, maps and a series of drawings similarly shown in the paper and electronic surveys (Figure 11 and 12). The survey questionnaire was tested and piloted before the data gathering phase. 
Figure 11: Study area Vuoksi River Basin District (left) and ecological status of lakes and rivers in the study area (right)
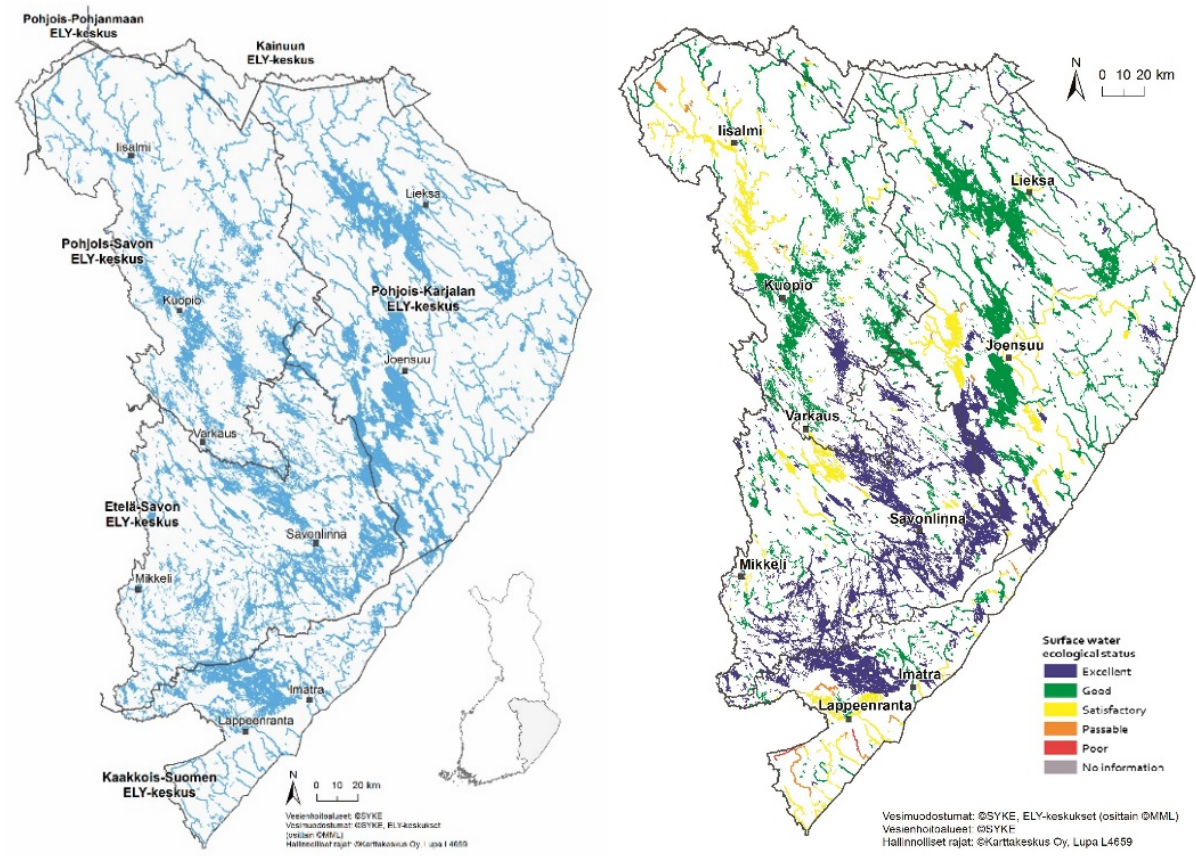
Figure 12: Three ecological status of rivers as presented in the survey questionnaire (Lehtoranta et al. unpublished)

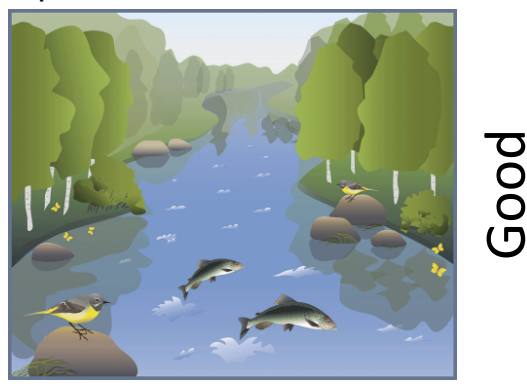

The river meanders and has a stable fish population and diverse bottom fauna. Water is clear, although may be darker where colored by humus. The river has free rapids with varying flow speeds. The river does not run dry in any season. There is water moss on stones at the river' edge and a moderate amount of aquatic plants along the bank.

Note, river restoration will not diminish the color of the water or (most of) water plants. The aim of restoration is to achieve good ecological status which is not always the most optimal solution for recreational purposes.

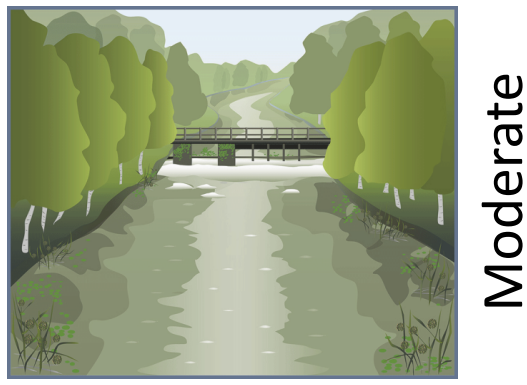

Rapids have been cleaned and river beds straightened. There may be obstacles for migratory fish, an old dam for example. Variation of flow is decreased and flow may sometimes be very slow. Water is dark and occasionally murky. River banks may suffer from erosion and water plants become common in places, causing problems for recreation. The amount of valuable fish is decreased and bottom fauna has lost its diversity.

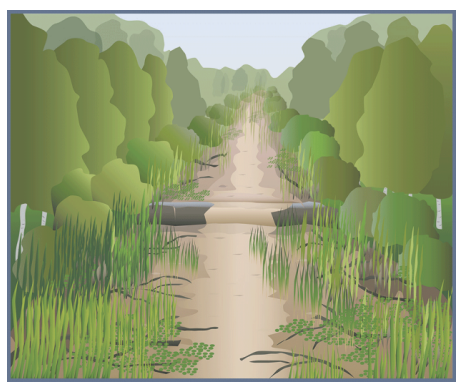 standing in places. Thick submerged and water side vegetation diminishes recreation and river fauna. Vegetal invasion of river waters and disruptive bottom vegetation may occur. Fishes are rare. Rich patches of common duckweed may appear at the surface. Water is dark and blurry, possibly greenish.

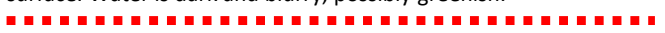

Altogether, $47 \%$ of the residents and $66 \%$ of non-residential cottage owners enjoy benefits from increased freshwater quality. There is, however, some spatial variation in the experience. A larger proportion of the residents in the south gain benefits due to increased freshwater quality compared to those in the northern part of the study area.

The residents of the Vuoksi river basin district were willing to pay EUR 22.4-36.0 on average per year during 2016-2021. Aggregated net present value of the benefits for all adult residents are EUR 50.1-80.6 million in 2016-2021 using a social discount rate of 3.5\%. The respondents owning a cottage had a higher willingness to pay for increased water quality, EUR 34.8-58.8 per person annually in 2016-2021. With a social discount rate of 3.5\%, this results in a net value of benefits of EUR 5.7-9.7 million during 2016-2021 (Lehtoranta et al. unpublished).

Due to differences in willingness to pay values between the north and south, a validity test was carried out to reveal the variation in the aggregated monetary benefit values. The aggregated benefit estimates are overestimated by EUR 2.0-3.8 million per year, if the mean WTP values of south are transferred to the northern area. Vice versa, the transfer of the northern WTPs to the southern area leads to an underestimation of 
benefits by EUR $1.3-2.5$ million per year. It was assumed that $40 \%$ out of the total population of 420,000 lives in the southern area.

The higher WTP values among residents were found to be associated with respondents having higher incomes and coming from the southern area. In addition, respondents were more likely to choose higher payments if they had children and if they considered reduction of peatland loading as an important goal of the freshwater management.

This example illustrates how such methods could help inform decisions on balancing conservation with use in practical terms. It illustrates how even a single category of social actors, in this case, different households, might assess quite differently the value of specific trade-offs based on their particular priorities and economic capacity. It also helps draw attention to issues or variables that might otherwise be overlooked. Even if decision makers must ultimately judge how the various priorities will be weighed against one another in practice, the use of this type of integrated knowledge can help make such balancing more precise and also reduce the social uncertainty that often accompanies regulatory decisions. 


\section{Current status of environmental accounting in the Nordic countries}

\section{Tea Nömmann and Virpi Lehtoranta}

The Nordic countries generally have had a long experience with environmental accounting. Norway and Sweden have been developing these accounts longest, with Finland and Denmark having caught up over the past decade, while Iceland is currently mapping its statistics towards potential future development of accounts.

In environmental accounting, there are two relevant and relatively recent studies reporting on the status of environmental accounting in the Nordic countries. The WAVES initiative, led by the World Bank, mapped the status of environmental accounts and their use in 12 mostly developed countries in 2013, including Denmark, Finland, Norway and Sweden (Smith 2014). Then in 2016, the Nordic Council of Ministers published a report about various Nordic indicators that have been compiled from the data in environmentaleconomic accounts (Björk et al. 2016). This second report focuses on the indicators and environmental-economic accounts that can be used to monitor and analyse economic factors on the environment, including pressures on the environment and policy responses. It highlights, for example, that there have been large data gaps in the water statistics reporting instrument jointly used by the OECD and Eurostat.

In 2013, The Nordic Ministers for the Environment decided to strengthen the measurement of green estimates of welfare and socioeconomic development to move beyond the constraints of economic development. The ad hoc working group on Complementary Measures for Welfare was established and given a mandate to consider how to integrate economic and environmental information and analysis through existing statistics. The working group suggested several avenues of development. These include recommending that existing statistical frameworks, national accounts and environmental accounts should be used to integrate economic data with environmental data; and that these accounts should then be used as a tool to analyse important policy issues, structural changes and important factors contributing to environmental pressures, "footprints", and policy instrument design (Björk et al. 2016). 


\subsection{A survey on the status of environmental accounts}

The survey carried out within this CAPITAL project aims to give an overview of new environmental accounts established in the Nordic countries within the last five years. This would allow comparisons with the aforementioned status reports and give insights into the potential future development plans regarding the environmental-economic accounts in these countries.

First, an electronic survey was carried out among Nordic Statistical offices in Finland, Sweden, Denmark, and Iceland in spring 2018. Then, at least one of the key statisticians in each of these countries was interviewed face-to-face or by phone. Table 4 summarizes the survey questions for the statistical experts.

Table 4: The questions and formula used in the electronic surveys and interviews

The questions and formula used in the electronic surveys and interviews

1. What are the concrete aims or tasks towards capital accounting at the moment and in the future, e.g., in a 5-year time period in your country?

2. What are the main challenges to further progress in the implementation of Natural Capital Accounting in your country in the next five year period?

3. Give an update about current users and use of natural accounts and the aims of this usage in your country.

4. Describe what freshwater statistics and accounts are being implemented or planned in your country.

5. What type of information does your national government or ministries have access to regarding the economic value of your country's freshwater capital at the moment?

6. Is there some other data that is related to the issue but not sufficient to be used for actual accounting purposes (e.g. valuation studies), any opinions about monetizing the value of some of the ecosystem services' simulated exchange values?

7. What kind of opportunities or linkages do you see for further working with existing (or still non-existing) freshwater accounts?

Table 5 shows the progress of environmental accounts in the Nordic countries compared to the previous overview study (Smith 2014). Since 2013, Nordic countries have expanded their existing accounts, broadened their use and established 13 new environmental accounts. The greatest progress has occurred in Denmark, where governmental funding during 20152017 enabled the development of a full set of new accounts. These include flow accounts for natural resources, materials and residuals, aspects of the green economy (environmental protection, environmental taxes, etc.) and stocks of natural resources.

Some modest progress can be seen in Sweden and Finland. For example, Swedish air emission accounts publication frequency was increased from annual to quarterly, which in turn raised some public discussions as air emission trends were varying over the new time scale. In Finland, an energy supply and use account has been added as an initiative by the Ministry of Finance. In addition, a water emission account was integrated into the existing water flow account.

The survey results clearly show that the EU initiative to develop compulsory environmental accounts module by module (EC regulations from 2011 and 2014) and also EU level circular economy goals have generally motivated environmental accounting in the Nordic countries. The UN SEEA framework has now been applied in most Nordic countries (except Iceland). 
Table 5: Development of environmental accounts in Denmark, Finland, Iceland, Norway and Sweden in 2013 (Smith, 2014) and in 2018 (this study)

\begin{tabular}{|c|c|c|c|c|c|c|c|c|c|c|c|}
\hline \multirow{2}{*}{\multicolumn{2}{|c|}{$\begin{array}{c}\text { Accounts } \\
\text { (compulsory by EC 2011, 2014) }\end{array}$}} & \multicolumn{5}{|c|}{$\begin{array}{l}\text { Environmental accounts in } 2013 \\
\text { (Waves, 2014)* }\end{array}$} & \multicolumn{5}{|c|}{$\begin{array}{l}\text { Environmental accounts in } \\
\qquad 2018^{* *}\end{array}$} \\
\hline & & DN & FI & SE & NO* & IS & DN & FI & SE & NO* & IS \\
\hline \multicolumn{2}{|l|}{ Air emissions (2011) } & $x$ & $x$ & $x$ & $x$ & & $x$ & $\mathrm{x}$ & $x$ & $x$ & \\
\hline \multicolumn{2}{|l|}{ Material flow (2011) } & $x$ & $x$ & $x$ & $x$ & & $x$ & $x$ & $x$ & $x$ & \\
\hline \multicolumn{2}{|l|}{ Environmental taxes (2011) } & $x$ & $x$ & $x$ & $x$ & & $x$ & $x$ & $x$ & $x$ & \\
\hline \multicolumn{2}{|l|}{ Energy use (2014) } & $x$ & & $x$ & $x$ & & $x$ & $x$ & $x$ & $x$ & \\
\hline Environmental Protection & Public sector & & $x$ & $x$ & $x$ & & $x$ & $x$ & $x$ & $x$ & \\
\hline Expenditure Accounts (2014) & Industry & & & & $x$ & & $x$ & $x$ & $x$ & $x$ & \\
\hline \multicolumn{2}{|l|}{ Water use } & & & $x$ & $x$ & & $x$ & & $x$ & $x$ & \\
\hline \multicolumn{2}{|l|}{ Water emissions } & & & $x$ & $x$ & & $x$ & & $x$ & $x$ & \\
\hline \multicolumn{2}{|c|}{ Experimental Ecosystem Accounts land-use based } & & & & & & & & $x$ & & \\
\hline \multicolumn{2}{|l|}{ Waste emissions } & & $x$ & & $x$ & & $x$ & $x$ & & $x$ & \\
\hline \multicolumn{2}{|l|}{ Environmental subsidies } & & & $x$ & & & & & $x$ & & \\
\hline \multicolumn{2}{|l|}{ Fish \& marine resources } & & & & $x$ & & $x$ & & & $x$ & \\
\hline \multicolumn{2}{|l|}{ Forest \& timber resources } & & $x$ & $x$ & $x$ & & $x$ & $x$ & $x$ & $x$ & \\
\hline \multicolumn{2}{|l|}{ Non-timber forest resources } & & & & $x$ & & & & & $x$ & \\
\hline \multicolumn{2}{|l|}{ Land cover / use } & & & & $x$ & & $x$ & & & $x$ & \\
\hline \multicolumn{2}{|c|}{ Oil \& natural gas / energy resources } & & & & $x$ & & $x$ & & & $x$ & \\
\hline \multicolumn{2}{|l|}{ Decomposition analysis } & & & $x$ & & & & & $x$ & & \\
\hline \multicolumn{2}{|c|}{ Environmental extended I-O tables } & & & $x$ & & & & & $x$ & & \\
\hline \multicolumn{2}{|c|}{ Environmental Accounts per country } & 4 & 7 & 12 & 13 & & 14 & 9 & 13 & 13 & \\
\hline \multicolumn{2}{|l|}{ Environmental Accounts total } & & & 36 & & & & & 49 & & \\
\hline
\end{tabular}

Note: *) WAVES, World Bank. Users and Uses of Environmental Accounts: A Review of Select Developed Countries, (Smith 2014). (https://www.wavespartnership.org/en/knowledge-center/users-and-usesenvironmental-accounts-review-select-developed-countries).

**) From the interviews carried out during the current study within the CAPITAL project and from literature when available.

According to our interviews, the main user categories do not appear to have changed from those presented by the WAVES project in 2013 (Smith 2014). As of that year, national government ministries or agencies were the most frequent users of the environmental account data and they have used them for a wide variety of purposes (Figure 13). The next largest demands for environmental account data came from international organizations and academic or research institutions, respectively. The former applies data for nearly as many different uses as national governments, while the latter's main usage has been informing the general public and public decision making. However, according to our interviews, the experts of Statistical Offices are not very familiar with the user side of environmental accounts. This familiarity differs between Statistical Offices, but globally the Nordic countries are at the forefront on knowing the users of the data. With increasing availability and accessibility of environmental economic accounts, the usage opportunities have expanded and it will become more challenging to define all the users. Further complicating this is the difficulty of defining users and uses that can vary greatly between and within institutions. 
Figure 13: Use of environmental accounts in 2013 of several institutions in Nordic countries

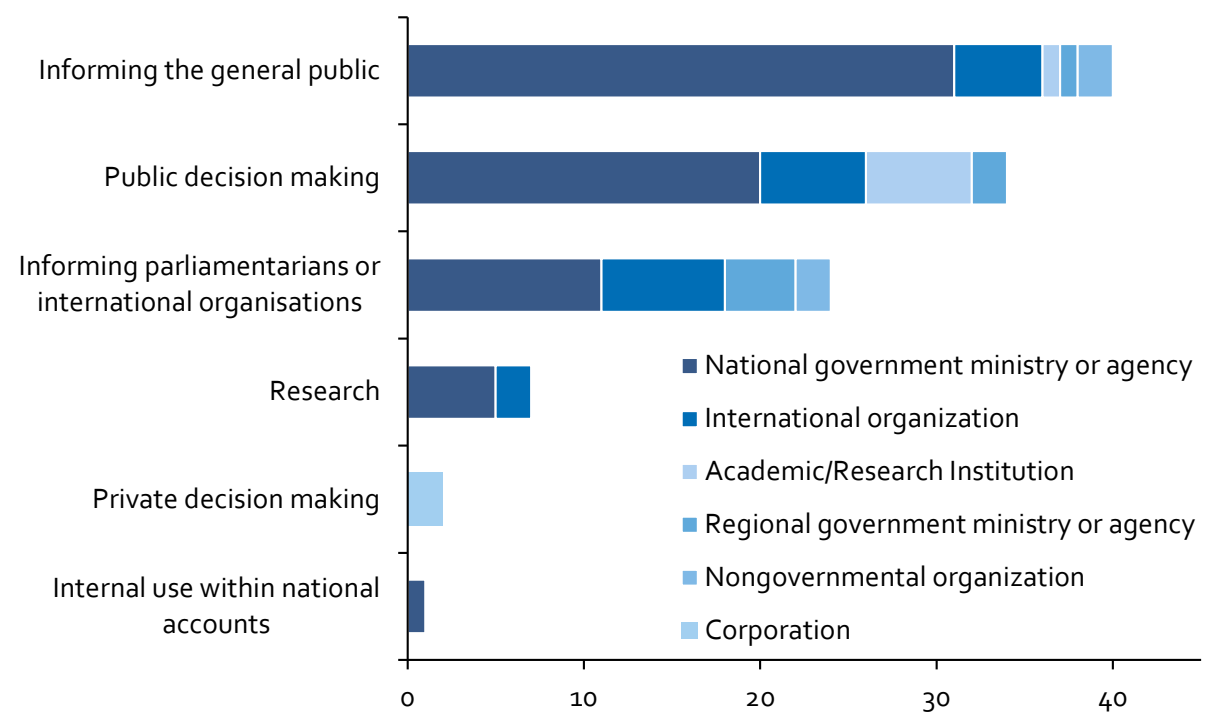

Note: A new analysis drawn from the appendixes of Smith (2014).

Our survey also sought information on the future development plans (next 5 years) of environmental accounts and their relevance to policy processes. From the ongoing policy processes perspective, the plans regarding: Inclusive Wealth, Sustainable Development Goals and indicators, Natural Capital Accounting and more precisely water accounting plans were explicitly sought.

Inclusive Wealth of Nations measures the value of the societal assets or capitals: produced capital,

For example, in Sweden currently, there is no official inclusive wealth monitoring (Adjusted Net Savings, Green National Income). Since 1994 the Swedish National Institute for Economic Research (NIER) had worked on this topic. Due to theoretical and empirical challenges the NIER asked to be relieved of this responsibility. However, the need has become more acute again, as the Agenda 2030 proposal suggests that governance should complement GDP with welfare measures and stronger sustainability requirements. Regarding the use of sustainable development indicators, the SDGs strategy and institutions are in place in Sweden. Statistics of Sweden also stressed the importance of using environmental accounts for monitoring and analysis of SDGs.

In Finland, the progress on sustainable development has been followed using a compilation of indicators for a long time. Upon the last update in 2013, it contains 39 different indicators. All these indicators are linked to the eight aims outlined in 
Society's Commitment of Sustainable Development - one of the key tools in implementing Agenda 2030 in Finland (Commission on Sustainable Development 2016). However, application of these indicators has remained limited (Commission on Sustainable Development 2017).

In Denmark, the Green GDP research project is implemented by the University of Copenhagen and Statistics Denmark (funded by KR Foundation and Carlsberg Foundation). The research project is focusing on two streams: the political, institutional and administrative barriers to the use of Green National Capital Accounting in Denmark; and adjusting the net domestic product for depletion of natural resources and degradation of the environment/ecosystems.

The experts interviewed expressed caution about the prospect of monetizing the value of some of the ecosystem services as simulated exchange values. According to the statisticians, monetizing changes in freshwater capital may be applicable in some cases - where reliable monetary information exists, preferably derived from market prices. Information on physical measures can also be of higher value than monetary values based on estimation methods perceived as unreliable.

\subsection{Freshwater accounts}

Table 6 presents the status of water accounts in the Nordic countries. At the moment there is no legal obligation to report emissions to water to Eurostat and such statistics are still partially under development both nationally and internationally. For example, Statistics Sweden has produced water accounts on an ad hoc basis, most recently in 2012. Statistics Denmark has developed water accounts which focus on water use, water supply and return flow as part of SEEA. The aim is to bring the statistics of water use and abstraction in line with the national accounts (Gravgård 2018).

Our interviews revealed that the development of water accounting has been occasional and driven by individual pilot studies in 2000 and 2018 in Finland. In Sweden, water accounts have been developed on request but there are no immediate plans for further development of water accounts. In Denmark, there are established water accounts and in Iceland there are statistics on water use (see Chapter 2.2) but no progress regarding freshwater accounting yet.

Some specific provisions of the WFD may require access to water accounts. To achieve the objectives of the WFD, the EU Member States must prepare Programmes of Measures that specify concrete actions and regulations, monitoring programs, and River Basin Management Plans (see Chapter 3). All Member States are required to prepare an economic analysis of water use for each river basin district. The Member States are also obligated to ensure that all water users contribute to the recovery of the costs of water services and that water-pricing policies provide adequate incentives for users to utilize water resources efficiently. 


\begin{tabular}{|c|c|c|}
\hline & Status of water accounts* & Frequency of water accounts \\
\hline Finland & $\begin{array}{l}\text { Supply and use tables for ground } \\
\text { water, surface water, brackish water } \\
\text { and mains water (Salminen et al. 2018) }\end{array}$ & Occasional \\
\hline Sweden & $\begin{array}{l}\text { Statistics and some accounts on } \\
\text { commission, water use and emissions } \\
\text { accounts (various ad hoc studies based } \\
\text { on water accounts) }\end{array}$ & $\begin{array}{l}\text { Irregular reports } \\
\text { Annual water statistics }\end{array}$ \\
\hline Norway & Water use, water emission & Annual \\
\hline Denmark & $\begin{array}{l}\text { Water flow accounts (in physical and } \\
\text { monetary terms), but data continuity } \\
\text { and continued publication threatened } \\
\text { due to lack of funding }\end{array}$ & Annual \\
\hline Iceland & $\begin{array}{l}\text { Statistics and single studies, no } \\
\text { accounts }\end{array}$ & Not started \\
\hline
\end{tabular}

The water abstraction and water consumption accounts of Denmark record the volumes of groundwater and surface water abstracted by industries, households and water utilities. The Danish return water flow accounts document the volume of wastewater generated by industries and households. The amount of wastewater produced in the individual regions of Denmark and the content of nitrogen, phosphorus and organic matter in the wastewater has also been assessed. In addition to a physical assessment of the amounts of water and wastewater reported in cubic metres, the water accounts include an assessment of the water and wastewater expenditure incurred by households and individual industries. Environmental goods and services accounts, environmental taxes and subsidies accounts, and environmental protection expenditures accounts also show what measures have been taken to protect water resources and water quality.

According to our interview with an official in Statistics Finland, water accounting has been studied and piloted in Finland since the beginning of 2000s. A comprehensive study is being conducted on water flow accounts for the year 2010, including detailed data on water use (Salminen et al. 2018) and data on water emissions (forthcoming). The Finnish Environment Institute (SYKE) is currently responsible for providing information about the status of the country's freshwater capital. The government and ministries have access to some information/calculated estimates from single studies about economic value of country's freshwater capital (e.g., Muukkonen 2003, Aaltonen et al. 2016). Regarding the development of freshwater accounts, collaboration between Statistics Finland and research institutes like SYKE is important, since Statistics Finland does not have any expertise on freshwaters. However, Statistics Finland sees water accounts as an important part of environmental accounting framework.

Statistics Iceland works in accordance with the Data Collection Manual for OECD/Eurostat Joint Questionnaire on Inland Waters and the European Environment Agency in accordance with the WISE SoE - Water Quantity (WISE-3) manual. Iceland is also involved in the Framework for the Development of Environmental 
Statistics classification of environmental data and is initiating work on environmental accounts in accordance with EU and Eurostat directions. Thus, in Iceland there are not yet clear and concrete aims regarding capital accounting, and no defined plans for the issues of inclusive wealth accounting, formally defined indicators or water accounting. In 2016, the Ministry for the Environment and Natural Resources started a still on-going primary phase project mapping the natural resources for natural capital accounting.

Water accounts in Sweden have been compiled irregularly and have focused on various aspects, as well as given input to the WFD process. For example, it has provided supplementary statistics for reporting economic analyses of the WFD. Water accounts have also been used to analyse economic structures and environmental pressures in river basin districts; compile environmental and economic profiles, and forecasts of water extraction and water use at the water district; and analyse the costs and income of municipalities and municipal companies for production and distribution of water and treatment of sewage. New opportunities and needs for water accounts are being elaborated in cooperation with the Swedish Water and Marine Agency.

Swedish Agenda 2030 is in the development process and the report "Towards a Sustainable Welfare" was handed out to the government in 2017 with six priority areas and a proposed action plan. During 2018-2019 additional consultations and studies on actions will be carried out in order to deliver the final report on the action plan. Priority areas are: equal society, sustainable cities, a socially responsible circular economy, a strong business community with sustainable business models, sustainable and healthy food, and strengthened knowledge and innovation.

Concerning measuring the progress towards SDGs, the Swedish Agenda 2030 delegation also suggested complementary measures to GDP and stronger sustainability requirements for investments. The SEEA framework and environmental economic accounts in Sweden provide a strong basis to support the development and usage of such measures. 


\section{Current and potential uses of water accounts - Finland}

Jani Salminen

\subsection{Water accounting}

Water accounting is a tool to connect water resources, their use and pollution to various economic activities. In this report, the recent case study for Finland (Salminen et al. 2018) elaborated in the CAPITAL project is used as an example to demonstrate how water accounts can be compiled and how the data therein can be further applied to answer multiple questions related to the interaction between water and the economy.

In water accounting, the flows of water from the environment to the economy, within the economy, and back to the environment are documented. The flow from the environment to the economy means that water from different sources -groundwater, fresh surface water bodies like lakes or rivers, or the sea - is abstracted for various purposes by humans. Water flows within the economy typically refer to water supply: water works extract water, treat it, and distribute (supply) it to their customers (users) via water mains. The customers then return it to the waste water treatment plant via the sewage system from which the treated wastewater is introduced back to the environment.

In water accounting, the above flows are linked to economic activities; in practice, to different sectors like agriculture, forestry, mining and quarrying, manufacturing industries, private and public services, and households. In the water accounting case study for Finland, annual water use volumes $\left(\mathrm{m}^{3}\right)$ were collected for 195 industries covering all of the above sectors of the economy as shown in Table 7. The compiled accounts document how much each of these industries use water and from which source this water is abstracted, i.e., if it is self-abstracted groundwater, fresh surface water or brackish water, or mains water bought from and delivered by the local water utility. The accounting also distinguishes between water used for cooling and for other purposes. The rationale for this is that cooling water is often extensive but has lower quality requirements and undergoes little changes in chemical quality upon its use. Industry-specific data on water abstraction and use can be associated with economic data obtained from standard national accounts. This can be accomplished once the water accounts are compiled according to the same statistical classification as the standard national accounts. In other words, the data in water accounts are compatible with the statistical classification of economic activities in the European Community (NACE codes) used by the European System of Accounts (European Commission 2013) and described in NACE Revision 2 by the European Commission (Eurostat 2008). 
This principle is also emphasized by the System of Environmental-Economic Accounting for Water (SEEA-Water) (United Nations 2012), which is the leading international documentation for water accounting.

Table 7: Illustration of water accounts combined with output values and employment data from standard national accountancy for a sample of industries. Mains water, ground water, fresh surface water and cooling water uses are recorded independently.

\begin{tabular}{|c|c|c|c|c|c|c|c|}
\hline \multirow[b]{2}{*}{ NACE } & \multirow[b]{2}{*}{ Industry } & \multirow[b]{2}{*}{$\begin{array}{c}\text { Output } \\
\text { (EUR mill.) }\end{array}$} & \multirow{2}{*}{$\begin{array}{l}\text { Employment } \\
\text { (1000 persons) }\end{array}$} & \multicolumn{4}{|c|}{ Water uset $\left(1000 \mathrm{~m}^{3}\right)$} \\
\hline & & & & Mains & Ground & $\begin{array}{l}\text { Fresh } \\
\text { surface }\end{array}$ & Cooling \\
\hline 101 & Meat prod. & $2,480.0$ & 7.4 & 3,559 & 1,517 & 0 & 0 \\
\hline 102 & Fish prod. & 251.0 & 1.2 & 0.21 & 6 & 0 & 0 \\
\hline 103 & Fruit \& vegetable prod. & 463.0 & 2.1 & 0.96 & 0 & 170 & 0 \\
\hline 104 & Oils and fats & 197.0 & 0.2 & 0.71 & 18 & 0 & 0 \\
\hline 105 & Dairy prod. & $2,449.0$ & 5.4 & 15.77 & 350 & 356 & 4,197 \\
\hline 106 & Grain mill \& starch prod. & 282.0 & 0.6 & 0.31 & 41 & 45 & 0 \\
\hline 107 & Bakeries, farinaceous prod. & $1,037.0$ & 9.2 & 0.83 & 38 & 0 & 0 \\
\hline 108 & Other food prod. & $1,528.0$ & 5.4 & 7.48 & 383 & 1,109 & 0 \\
\hline 109 & Animal food prod. & 547.0 & 1.0 & 0.24 & 12 & 2 & 0 \\
\hline 11 & Beverages & $1,153.0$ & 3.8 & 6.79 & 3,112 & 413 & 58 \\
\hline 13 & Textiles & 513.0 & 4.9 & 2.25 & 34 & 0 & 665 \\
\hline 14 & Wearing apparel & 533.0 & 5.0 & 0.64 & 23 & 113 & 0 \\
\hline 15 & Leather prod. & 191.0 & 2.5 & 0.46 & 15 & 192 & 5 \\
\hline 161 & Timber \& sawmilling & $2,859.0$ & 8.2 & 0.53 & 41 & 1,302 & 0 \\
\hline 162 & Wood prod. & $2,639.0$ & 17.3 & 6.97 & 352 & 833 & 2,537 \\
\hline 171 & Pulp, paper \& cardboard & $12,626.0$ & 18.9 & 1,061 & 216 & 472,529 & 610,313 \\
\hline 172 & Paper \& cardboard prod. & 848.0 & 4.1 & 18.33 & 0 & 8,825 & 0 \\
\hline
\end{tabular}

Source: Salminen et al. (2018).

The value of sophisticated water accounts lies in their many applications (Figure 14). In other words, water accounts are a key tool to answer multiple questions related to the environmental and economic aspects of water resources and their use. That said, even though the compilation of highly disaggregated high-quality water use accounts is a laborious exercise, such water accounts constitute a solid basis for other applications that can be more easily developed. First, water use accounts are essential for the compilation of waste water accounts. Once the volumes of water used by each industry are known, the return flows can be estimated by using the former accounts as a starting point. Once the waste water accounts are produced, they can be 
supplemented with water emission accounts containing industry-specific data on nutrient loads. Moreover, waste water and emission accounts are of great value for the efficiency assessment of water protection measures taken by different industries. National water use accounts can be also downscaled to a geographically delineated regional scale. This kind of delineation can, for instance, correspond to the river basin districts. Such regional water accounts can then be compared with the water assets on that region to assess the sustainability of the use of water resources. In a similar manner, regional waste water accounts can be derived from the national level data and analysed together with the regional water quality data. Data from water, waste water and emission accounts can be taken into environmentally-extended input-output model provided that the data in the accounts is sufficiently disaggregated. Water-amended input-output modelling allows interesting opportunities e.g. for studying water issues in the contexts of circular economy and international trade. In the following sub-chapters, we describe some of these applications to illustrate why water accounts are highly relevant. We also describe the experiences gathered during the compilation of the first national water accounts for Finland, concluding with the CAPITAL project.

Figure 14: Potential applications of national water accounts

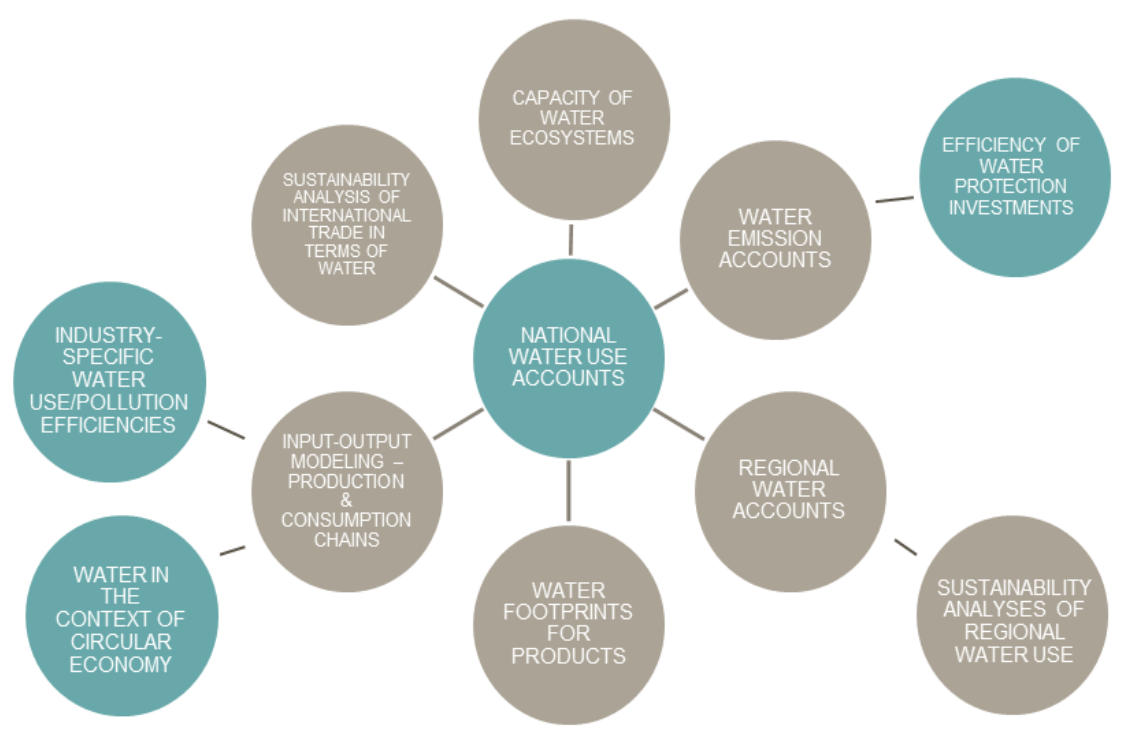




\subsection{Experiences from the compilation of the national water accounts}

Water flow accounts from the environment to the economy and within the economy were recently compiled for the first time for Finland. These accounts document annual water abstraction rates from the environment and mains (drinking) water use rates to the 195 industries in the Finnish economy (Salminen et al. 2018). The data distinguishes groundwater, fresh surface water, brackish water, and mains water and separates cooling water use from other uses. The work also describes a quality protocol by which the issues related to data coverages and gaps, and potential sources of error can be addressed and reported in a transparent manner.

Water accounts are typically reported for only about 30 industries. However, such poor sectoral disaggregation, does not allow for further analyses such as input-output modelling that require substantially more detailed data. Environmentally-extended input-output model for the Finnish economy (ENVIMAT10) (Koskela et al. 2011, Seppälä et al. 2011), for instance, differentiates between 150 industries. Hence, to include water use in this model, data for these 150 industries on water use has to be at hand. Until recently, such figures have not been available and water has been excluded from the analyses on the interactions between the Finnish economy and the environment performed by using this model (e.g., Koskela et al. 2011, Seppälä et al. 2011). In the international scientific literature, modelled data, prone to errors and inconsistencies of an unknown level, are almost exclusively used for the water-related input-output analyses (e.g., Steen-Olsen etal. 2012, Vanham and Bidoglio 2013, Tukker et al. 2014, Wood et al. 2015). In conclusion, there is an urgent need for high quality data on water use and emissions to water. This way, the considerable uncertainties in the water-related studies on the interactions between economies and environment can be mitigated.

The compilation of water accounts for Finland contained following phases: First, data requirements for the final use, ENVIMAT10, were determined - data on water use were needed for 150 industries. Second, additional industries with relevant water uses were recognized so that the water accounts would reliably cover all major water users and thus provide a comprehensive picture of the water use of the Finnish economy. Third, the relevant water source categories were determined to be groundwater, fresh surface water, and brackish water.

After these steps, potential sources of raw data for water abstraction and use were mapped. This analysis resulted in the combined use of multiple data sources, as no single source could cover all relevant industries (major sources presented in Table 8). Despite this effort, the compiled data only represented a subset of the economy, with coverage varying from industry to industry. However, the outcome, that is, the water accounts, should represent the water use of the entire industry and not just the subset collected, which in some cases covered less than 1 percent of the activities (enterprises) operating in an industry. To this end, we used so called aligning parameters. For manufacturing industries, for instance, we used revenue as a means to compare the extent of our subset to the activity of each industry on the national level. 
Table 8: Key data sources for economic activities and for water abstraction and use, and their application for various industries

\begin{tabular}{lll}
$\begin{array}{l}\text { Data sources for economic } \\
\text { activities }\end{array}$ & Applicable industries & Data sources for water abstraction and use \\
\hline Cultivated land area & Growing crops & Plant-specific water needs \\
Animal numbers & Animal husbandry & Animal-specific water needs \\
\hline $\begin{array}{l}\text { Revenues } \\
\text { Number of employees in regional } \\
\text { entrepreneurial activities }\end{array}$ & Services & $\begin{array}{l}\text { Envires } \\
\text { environmental permits and their surveillance, }\end{array}$ \\
\hline $\begin{array}{l}\text { Industrial output } \\
\text { Population structure }\end{array}$ & Manufacturing industries & Environmental permits \\
\hline Register on buildings and dwellings & Public sector & Public reports \\
\hline
\end{tabular}

From the very beginning it was evident that compilation of the water accounts would be a relatively labour-extensive and time-consuming exercise. To limit the amount of work, and to focus on the methodological development, accounts were only compiled for one year, 2010. Other environmental-economic accounts, including the use of natural resources and emissions had previously been collected for that year.

The aim was to follow the SEEA-Water framework; however the work revealed some shortcomings in the framework. For instance, volumetrically very significant cooling water flows are only considered for energy industry although their contribution is highly relevant for many other industries, such as food and beverage, paper and pulp, chemical and basic metal industries, as well. Other aspects requiring further clarity in SEEA-Water framework are attributed to how soil water is addressed in the accounting.

Within the SEEA framework, there is guidance related to water, water resources and ecosystems both in the SEEA-Water and the SEEA-EEA guidelines. The SEEA-Water framework deals with the flows of water from the environment to the economy, within the economy and ultimately back to the environment. Included in the framework are flows of soil water and regulated water. Curiously, the guidance only recognizes soil water in the context of agriculture (growing of crops) and regulated discharge in energy production (hydroelectric power generation). In the Nordic and Arctic contexts, however, forests transpire extensive volumes of water indifferent to whether they are used, for instance, as nature conservation areas or for harvesting timber (forestry) (Launiainen et al. 2014). Multiple in-stream uses of fresh surface waters also exist, such as freshwater aquaculture and water traffic. In our view, systematic consideration of water, water resources and ecosystems in the accounting and clarifications between the different SEEA approaches would be highly beneficial. Lai et al. (2018) and Salminen et al. (2018) have suggested making a distinction between abstractive and non-abstractive uses of water in the economy. The former type of water 
use would fit with water accounting as it is presented in the recent water accounts for Finland (Salminen et al. 2018), while the latter could be incorporated into (water) ecosystem accounting. Further details regarding the implication of the current work on the SEEA-Water framework can be found in Salminen et al. (2018).

Also, quality assessment frameworks were missing and needed to be introduced. Availability of data is naturally a key challenge in any environmental accounting. In our concept, water abstraction and use characterization data is needed for all of the industries included in the accounting. For many of them, data were available from the environmental administration, environmental permits or public reports. However, data requests made by phone were also required. For many service sectors without specific water use, a general, employee-based water use rate was assumed. Water use data also needed considerable data quality control and evaluation.

Despite the considerable efforts required, the accounting concept and the data provided by it can now be used for multiple purposes explained in the following subchapters. On one hand, it is evident that compilation of the raw data for water accounts is not feasible on annual basis. On the other hand, rapid changes in the patterns of water abstraction and use are unlikely to happen in Finland or similar countries. Therefore, data collection could be repeated every 5 years by using the existing data sets as the basis for this data collection making the data collection and analysis phase less time-consuming. As yet, this phase cannot be automated.

\subsection{Regional water accounts}

Water resources are unequally distributed in terms of geography. In global scale the differences are remarkable and can be visualized by water scarcity maps (Pfister et al. 2009). In water-scarce regions, demand for clean freshwater may exceed its supply, which results in overconsumption of e.g. groundwater, gradually leading to decreasing levels of groundwater elevation. In Arctic and subarctic regions water resources are often abundant and demand for water much lower than that in the southern latitudes. In Finland, for instance, 1.4 percent and roughly 10 percent of the nation's renewable groundwater and fresh surface water resources are abstracted annually (Meriläinen et al. 2017). Regionally, however, freshwater assets with sufficiently high quality may not meet the needs of the economies even in these northern areas. Regional water accounts can be used to evaluate the sustainability of the use of the regional water resources. Figure 15 illustrates how regional water accounts can be generated from national water accounts and existing statistical data. 
Figure 15: Illustration of the downscaling of national water accounts

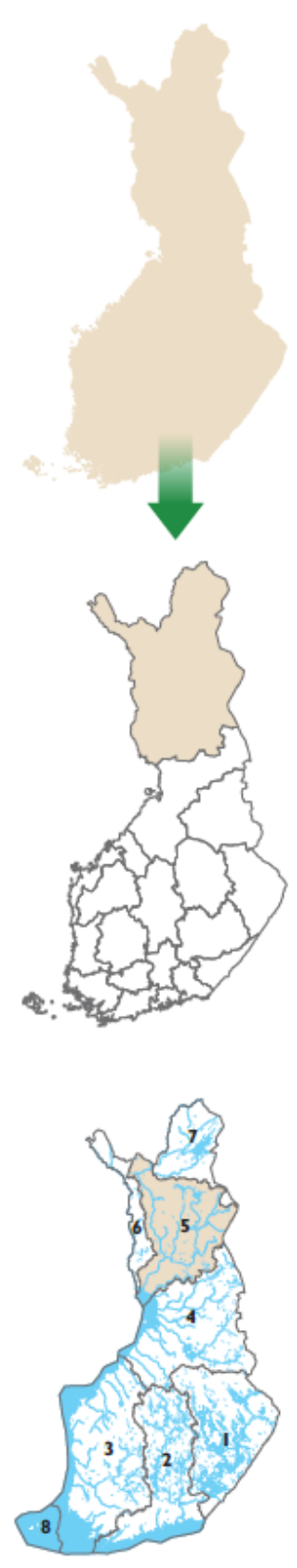

\begin{tabular}{|c|c|}
\hline \multicolumn{2}{|c|}{ NATIONAL WATER ACCOUNTS } \\
\hline Industry & Water use $\left(m^{3}\right)$ related to economic activity \\
\hline Agriculture, forestry \& fishing & $\begin{array}{l}\mathrm{m}^{3} / \mathrm{m}^{2} \text { (of cultivated land), } \mathrm{m}^{3} / \text { animal number, } \mathrm{m}^{3 / \epsilon} \\
\text { (revenue) }\end{array}$ \\
\hline Mining \& quarrying & $\mathrm{m}^{3} / \epsilon$ (revenue) \\
\hline Manufacturing & $\mathrm{m}^{3} / \epsilon$ (revenue) \\
\hline Energy, water \& waste & $\mathrm{m}^{3} / €$ (revenue), $\mathrm{m}^{3} /$ inhabitant \\
\hline Construction & $\mathrm{m}^{3} / \epsilon$ (revenue) \\
\hline Trade & $\mathrm{m}^{3} / \mathcal{\epsilon}$ (revenue) \\
\hline Transportation & $\mathrm{m}^{3} / \epsilon$ (revenue) \\
\hline Accommodation \&food services & $\mathrm{m}^{3} / \epsilon$ (revenue) \\
\hline Information \& communication & $\mathrm{m}^{3} /$ number of employees \\
\hline Financial and insurance activities & $\mathrm{m}^{3} /$ number of employees \\
\hline Professional and technical activities & $\mathrm{m}^{3} /$ number of employees \\
\hline $\begin{array}{l}\text { Public administration, education \& } \\
\text { health }\end{array}$ & $\mathrm{m}^{3} / \mathrm{m}^{2}$ (of floor area) \\
\hline Arts, entertainment \&recreation & $\mathrm{m}^{3} / \mathrm{m}^{2}$ (of floor area), $\mathrm{m}^{3} / €$ (revenue) \\
\hline Other services & $\mathrm{m}^{3} / \mathcal{\epsilon}$ (revenue) \\
\hline
\end{tabular}

\section{REGIONAL ECONOMIC ACTIVITIES}

\begin{tabular}{|l|l|}
\hline Industry & Measure of economic activity \\
\hline Agriculture, forestry \& fishing & $\begin{array}{l}\text { cultivated area }\left(\mathrm{m}^{2}\right) \text {, numbers or animals, revenues } \\
(\boldsymbol{\epsilon})\end{array}$ \\
\hline Mining \& quarrying & revenues in $\boldsymbol{\epsilon}$ \\
\hline Manufacturing & revenues in $\boldsymbol{\epsilon}$ \\
\hline Energy, water \& waste & revenues $(\boldsymbol{\epsilon})$, number of inhabitants \\
\hline Construction & revenues $(\boldsymbol{\epsilon})$ \\
\hline Trade & revenues $(\boldsymbol{\epsilon})$ \\
\hline Transportation & revenues $(\boldsymbol{\epsilon})$ \\
\hline Accommodation \&food services & revenues $(\boldsymbol{\epsilon})$ \\
\hline Information \& communication & number of employees \\
\hline Financial and insurance activities & number of employees \\
\hline Professional and technical activities & number of employees \\
\hline $\begin{array}{l}\text { Public administration, education \& } \\
\text { health }\end{array}$ & built area $\left(\mathrm{m}^{2}\right)$ \\
\hline Arts, entertainment \&recreation & built area $\left(\mathrm{m}^{2}\right)$, revenues $(\boldsymbol{\epsilon})$ \\
\hline Other services & revenues $(\boldsymbol{\epsilon})$ \\
\hline \multicolumn{2}{|l}{} \\
\hline
\end{tabular}

\begin{tabular}{|l|l|}
\hline Industry & Regional water use $\left.\mathbf{( m}^{\mathbf{3}}\right)$ \\
\hline Agriculture, forestry \& fishing & $\ldots$ \\
\hline Mining \& quarrying & $\ldots$ \\
\hline Manufacturing & $\ldots$ \\
\hline Energy, water \& waste & $\ldots$ \\
\hline Construction & $\ldots$ \\
\hline Trade & $\ldots$ \\
\hline Transportation & $\ldots$ \\
\hline Accommodation \&food services & $\ldots$ \\
\hline Information \& communication & $\ldots$ \\
\hline Financial and insurance activities & $\ldots$ \\
\hline Professional and technical activities & $\ldots$ \\
\hline Public administration, education \& & $\ldots$ \\
\hline health & $\ldots$ \\
\hline Arts, entertainment \& recreation & $\ldots$ \\
\hline Other services & $\ldots$ \\
\hline
\end{tabular}

Note: Downscaling can be performed to administrative regions such as the Finnish Lapland (in brown, middle) or to river basin districts (RBD). RBD-5 (in brown, below) and the seven other RBDs in Finland are indicated. 
Figure 15 demonstrates the principles for downscaling national water accounts. For this purpose, relevant allocation parameters are first chosen. They are primarily the same used in the compilation of the initial national water accounts by Salminen et al. (2018) but other parameters can be chosen as well when feasible. Data on these allocation data are then collected from existing statistical sources. To exemplify, industry-specific data on revenues are collected for a region. Regional water use rates $\left(\mathrm{m}^{3} / \mathrm{a}\right)$ for various industries are then estimated by a simple calculation: the national water use rate is divided by the volume of activity of an industry at a national level and multiplied with the corresponding activity on a regional level. For instance, water use rate for a specified manufacturing industry is divided by the total sum of revenues in Finland and multiplied with the total revenue of that industry in the region under study.

Sectoral water use volumes for 16 aggregated industries in the Finnish Lapland are summarized in Figure 16 in Chapter 5.4. Fresh surface water and groundwater assets for the same area are documented in Table 9.

Table 9: Fresh surface water and groundwater assets in the Finnish Lapland. Number of lakes and groundwater aquifers and their total surface areas are given together with the total volume of water in these lakes and the estimated total productivity of these aquifers. Annual total flow in the rivers is also given

\begin{tabular}{ccc|c|ccc} 
& \multicolumn{2}{c|}{ Lakes } & Rivers & \multicolumn{3}{|c}{ Aquifers } \\
Number & $\begin{array}{c}\text { Surface area } \\
\left(10,000 \mathrm{~m}^{2}\right)\end{array}$ & Water volume $\left(\mathrm{m}^{3}\right)$ & $\begin{array}{c}\text { Flow } \\
\left(106 \mathrm{~m}^{3} / \mathrm{a}\right)\end{array}$ & Number & $\begin{array}{c}\text { Surface area } \\
\left(10,000 \mathrm{~m}^{2}\right)\end{array}$ & $\begin{array}{c}\text { Productivity } \\
\left(\mathrm{m}^{3} / \mathrm{a}\right)\end{array}$ \\
\hline 21,213 & 556,430 & $13,664,613,000$ & 41 & 2,077 & 301,828 & $374,660,820$ \\
\hline
\end{tabular}

The aquifers included in the data cover groundwater areas important and suitable for water supply (classes 1 and 2) and other groundwater areas (classes 3 and E). Locally, a permit is required for groundwater abstraction if water is abstracted in larger quantities than that of a regular household. When granting a permit for groundwater abstraction, impacts on e.g. groundwater elevation, on ecosystems dependent on groundwater, and on groundwater abstraction by households or operators abstracting water from the same aquifer, are considered according to the Water Act. Thus, productivity volumes reported here are not to be regarded as volumes that can be abstracted. In this context they are a simple indicator of regional groundwater assets.

\subsection{Water emission accounts}

Water flows from the environment to the economy contain water volumes that are abstracted by humans to different uses in the economy. Part of the abstraction is carried out by the water supply industry - public and private water utilities and cooperatives - that treat the raw water they have abstracted to produce drinking water. They then deliver it to their customers via water mains. The return flows within the economy document those water volumes that various actors introduce to sewerage and subsequently to waste water treatment plants. Return flows from the economy to 
the environment mean treated or untreated waste waters or other used waters that are introduced to the environment. Pollution discharged into surface water bodies along with the return water flows has adverse impacts on water ecosystems. They can be attributed to eutrophication caused by nutrients or toxic impacts resulting from hazardous substances. Other stressors including, heat load or micro-organisms also have potential impacts on water ecosystems and the services they provide.

Water emission accounts help to understand how different industries contribute to the overall load of contaminants dissolved in water returned to the environment. For their compilation, accounts for the abstracted water and mains water are an invaluable asset. Once we know how much water different industries use and consume (i.e., incorporate into their products), we can reliably estimate the water volumes they return. In addition, data on the qualities of the waste waters and the efficiencies of substance-specific removal rates at wastewater treatment plants are needed to populate the return flow and water emission accounts.

Return flow and water emission accounts can also be compiled for regional level on the basis of national accounts in a similar way to the method explained in the previous Chapter (5.3). In this way, for regions like the Finnish Lapland, contributions of different industries to the overall water emissions can be documented. Emissions to water by different industries can then be compared with data on water quality in the water bodies of a geographically delineated area. This is exemplified in Figure 16, while the distribution of lakes, rivers, and aquifers (in classes 1, 2, 3, and E) to different ecological or chemical classes are presented in Table 10. To obtain regional water emission accounts, regional water accounting data is first generated on the basis of national water flow accounts (see Chapter 5.3). Then, by using industry-specific water emission characteristics, the contribution of each industry to the water quality asset accounts can be estimated. Such an approach can also be used when assessing the potential water-related impacts of potential changes in economic activities as demonstrated in Chapter 2. 
Figure 16: Estimated regional freshwater use volumes in the Finnish Lapland in 2010 are presented for 16 aggregated industries

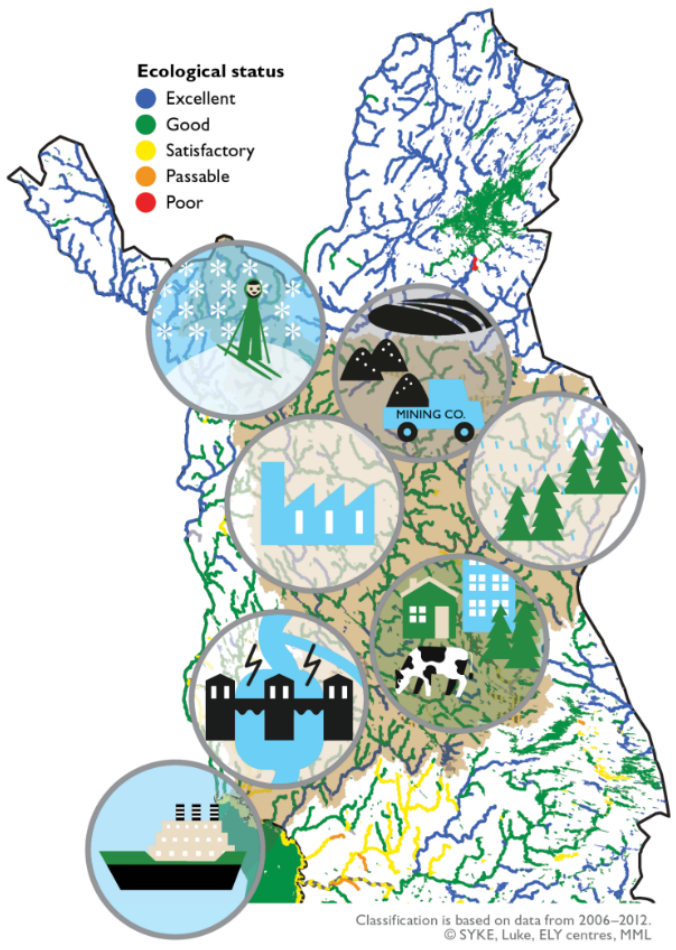

\begin{tabular}{|c|c|c|}
\hline \multicolumn{3}{|c|}{ REGIONAL WATER USE } \\
\hline Industry & \multicolumn{2}{|c|}{$\begin{array}{l}\text { Regional water use } \\
\qquad\left(1000 \mathrm{~m}^{3}\right)\end{array}$} \\
\hline Agriculture, forestry \& fishing & \multicolumn{2}{|c|}{138370} \\
\hline Mining \& quarrying & \multicolumn{2}{|c|}{2319} \\
\hline Manufacturing & \multicolumn{2}{|c|}{159686} \\
\hline Energy, water \& waste & \multicolumn{2}{|c|}{19371} \\
\hline Construction & \multicolumn{2}{|c|}{3,7} \\
\hline Trade & \multicolumn{2}{|c|}{166} \\
\hline Transportation & \multicolumn{2}{|c|}{35} \\
\hline Accommodation \&food services & \multicolumn{2}{|c|}{785} \\
\hline Information \& communication & \multicolumn{2}{|c|}{12} \\
\hline Financial and insurance activities & \multicolumn{2}{|c|}{4,1} \\
\hline Professional and technical activities & \multicolumn{2}{|c|}{289} \\
\hline Public administration, education \& health & \multicolumn{2}{|c|}{329} \\
\hline Arts, entertainment \&recreation & \multicolumn{2}{|c|}{160} \\
\hline Other services & \multicolumn{2}{|c|}{175} \\
\hline Households & \multicolumn{2}{|c|}{8505} \\
\hline \multicolumn{3}{|c|}{ REGIONAL WATER EMISSIONS } \\
\hline \multirow[t]{2}{*}{ Industry } & \multicolumn{2}{|c|}{$\begin{array}{l}\text { Regional water } \\
\text { emissions (kg) }\end{array}$} \\
\hline & Phosphorus & Nitrogen \\
\hline Agriculture, forestry \& fishing & $\ldots$ & $\ldots$ \\
\hline Mining \& quarrying & $\ldots$ & $\ldots$ \\
\hline Manufacturing & $\ldots$ & $\ldots$ \\
\hline Energy, water \& waste & $\ldots$ & $\ldots$ \\
\hline Construction & $\ldots$ & $\ldots$ \\
\hline Trade & $\ldots$ & $\ldots$ \\
\hline Transportation & $\ldots$ & $\ldots$ \\
\hline Accommodation \&food services & $\ldots$ & $\ldots$ \\
\hline Information \& communication & $\ldots$ & $\ldots$ \\
\hline Financial and insurance activities & $\ldots$ & $\ldots$ \\
\hline Professional and technical activities & $\ldots$ & $\ldots$ \\
\hline Public administration, education \& health & $\ldots$ & $\ldots$ \\
\hline Arts, entertainment \&recreation & $\ldots$ & $\ldots$ \\
\hline Other services & & \\
\hline
\end{tabular}

Note: Estimated regional freshwater use volumes in the Finnish Lapland in 2010 are presented for 16 aggregated industries. Similar industry-specific water emission accounts can be documented but data for their compilation has not been accomplished yet. Ecological status of the surface water bodies in that region in 2006-2012 are indicated on the map together with the relevant economic activities in the Finnish Lapland and in the area of RBD-5 (indicated with brown colour).

Table 10: Distribution of lakes and rivers (in parentheses) into the different classes of ecological status as percentage, the number of aquifers important or suitable for water supply into good and poor chemical status, and the total number of aquifers classified important or suitable for water supply. All figures are for the Finnish Lapland. For lakes, the percentages are calculated based on the surface area, for the rivers based on the length

\begin{tabular}{|c|c|c|c|c|c|c|c|c|}
\hline \multicolumn{5}{|c|}{ Lakes and rivers } & \multicolumn{4}{|c|}{ Aquifers } \\
\hline \multicolumn{5}{|c|}{ Ecological status } & & \multicolumn{3}{|c|}{ Chemical status } \\
\hline Excellent & Good & Satisfactory & Passable & Poor & & Good & Poor & No data \\
\hline $24(43)$ & $61(52)$ & $15(4.5)$ & $0(0)$ & $0(0.08)$ & 2,077 & 966 & 1 & 1,110 \\
\hline
\end{tabular}




\subsection{Water footprints of products and services}

In water accounting, water use volumes and water emissions of different substances are presented for different industries. Environmentally-extended input-output (EE-IO) modelling is a method that allows combining these data to different commodities products and services. It is also used to investigate the use of natural resources like water and generation of pollution along the entire life cycle of these commodities.

IO-models combine the activities of different industries with each other and take advantage of data that documents how each industry uses intermediary products and services from other industries. Let us use dairy industry as an example to describe this method (Figure 17). Dairies use e.g. raw milk delivered by dairy cattle farms in the production of various dairy products. At the dairy cattle farms producing the raw milk, different natural resources, water included, are used. The farms also buy e.g. machinery and services to maintain their operation. In EE-IO modelling, the indirect consumption of natural resources and emissions to the environment, are calculated because the interactions between the different industries are known. Thus, in the case of dairy industries, this indirect consumption and pollution incorporated in the services and production chains are summed up to come up with a total "footprint" of an industry and the commodities provided by it. In our case example, water is needed e.g. at the factory producing the machinery used at the farm. Then at a farm, water is used e.g. to feed the animals. Finally, at the dairy water is used in the production of the dairy products. The total water footprint of the dairy products is then formed by summing up these water uses along the production chains by using complex mathematical equations. In this way, it is possible to calculate the water volumes needed or water pollution generated along the entire production chain of e.g. one litre of canned milk or one kilogram of cheese.

Figure 17: Environmentally-extended input-output modelling estimates water use and water pollution generated along chains of production and consumption

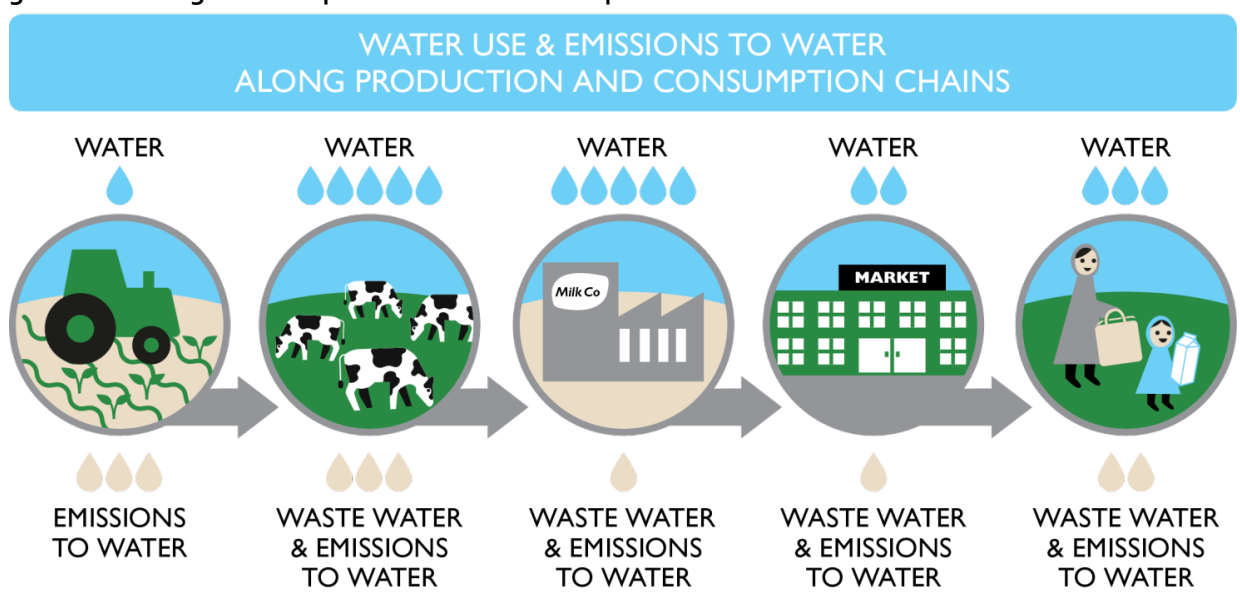




\title{
6. Economic and environmental impact analyses using ecosystem accounting
}

\author{
Johanna Pohjola, Jani Salminen, Jani Laturi and Hannu Savolainen
}

Typically, Natural Capital Accounting (NCA) is used to record the current status and past development of the economy or environment. In this chapter, we show how the results from a forward-looking policy/scenario impact analysis can be presented in the NCA framework.

For this study, we investigate the economic and environmental impacts of a new pulp mill. Expansion of the forest industry was chosen for the case study because the industry is among the most important users of freshwater and forests are an important ecosystem in Lapland. In addition to raw material for the forest industry, forests provide regulating and cultural ecosystem services. Because the mitigation of climate change is one of the most important issues for Arctic region, here we focus on the trade-offs between wood production and carbon sequestration.

The ambition of bioeconomy is to shift the use of natural capital from fossil fuels and other non-renewable resources to renewable resources. In Nordic countries, forests are the main renewable resource. However, the bioeconomy boom may threaten the provision of forest-based ecosystem services. The increased cuttings of timber reduce the amount of carbon sequestration and carbon storage as well as biodiversity; and may weaken the recreation and nature tourism possibilities. In addition, the production of biobased products often requires intensive water use and produces emissions to water bodies. The economic benefits arising from new bioeconomy production are shown in the standard national accounting while most of the environmental losses are missing. By expanding accounting practices to also cover non-market impacts on ecosystems, more balanced information on the total impacts of alternative scenarios can be provided to decision makers.

\subsection{Scenarios, indicators and models applied in the analyses}

We illustrate the economic and environmental impacts of a new pulp mill by comparing two scenarios: Business as Usual (BAU) and New Pulp Mill (PulpMill). In the PulpMill scenario the capacity of pulp production in Finnish Lapland is increased by 500,000 tonnes. The higher capacity level leads to an increase in total production by 400,000 tonnes of pulp. Our example is illustrative and does not represent any actual investment plan. 
First we assess how the new pulp mill affects the direct and indirect water use in different industries (Chapter 6.2). The analysis is based on the national water accountancy presented in Chapter 5 . Second, we focus on the forest ecosystem and assess the impacts of new pulp mill on the forest stock (Chapter 6.3.1) and forest asset value (Chapter 6.3.2). We illustrate trade-offs between forest ecosystem services (Chapters 6.3.2 and 6.3.3), as well as leakage of the impacts to other regions (Chapter 6.3.4). Impacts of the new pulp mill are assessed by combining economic-ecological modelling with NCA. We provide physical and monetary asset accounts, as well as, physical and monetary ecosystem supply accounts according to SEEA-CF (United Nations et al. 2014b) and SEEA-EEA (UNEP et al. 2017) guidelines. Finally, we focus on the whole economy and combine systems of national accounts and NCA in assessing the impacts of a new pulp mill. We illustrate trade-offs between the economy and environment, both in monetary and physical terms (Chapter 6.4).

Economic and environmental impacts of the new pulp mill are obtained by using two existing models, the forest sector model FinFEP (Lintunen et al. 2015) and the economy-wide, environmentally-extended input-output model ENVIMAT10 (Seppälä et al. 2011). We use several economic and ecological indicators in monetary and physical units to assess economic and environmental impacts for Finnish Lapland and the whole of Finland. The indicators, models from which they are obtained and accounts produced are presented in Table 11.

Table 11: Indicators, associated models and accounts produced

\begin{tabular}{|c|c|c|c|c|}
\hline Indicator & $\begin{array}{l}\text { Regional } \\
\text { coverage }\end{array}$ & Model & Accounts produced & Sub-chapter \\
\hline \multicolumn{5}{|l|}{ Environment } \\
\hline Use of freshwater & Finland & ENVIMAT10 & Water account (physical) & $6.2,6.4$ \\
\hline $\begin{array}{l}\text { Forest stock and its } \\
\text { changes }\end{array}$ & $\begin{array}{l}\text { Finnish Lapland, } \\
\text { Finland }\end{array}$ & FinFEP & Physical asset account & 6.3 .1 \\
\hline Forest asset value & $\begin{array}{l}\text { Finnish Lapland, } \\
\text { Finland }\end{array}$ & FinFEP & Monetary asset account & $6.3 .2,6.3 .4$ \\
\hline Carbon sink & $\begin{array}{l}\text { Finnish Lapland, } \\
\text { Finland }\end{array}$ & FinFEP & $\begin{array}{l}\text { Supply account, combined presentation } \\
\text { (monetary and physical) }\end{array}$ & $6.3 \cdot 3,6.4$ \\
\hline Timber production & $\begin{array}{l}\text { Finnish Lapland, } \\
\text { Finland }\end{array}$ & FinFEP & $\begin{array}{l}\text { Supply account, combined presentation } \\
\text { (monetary and physical) }\end{array}$ & $6.3 \cdot 3,6.4$ \\
\hline \multicolumn{5}{|l|}{ Economy } \\
\hline GDP & Finland & ENVIMAT10 & Combined presentation (monetary) & 6.4 \\
\hline Employment & Finland & ENVIMAT10 & Combined presentation (non-monetary) & 6.4 \\
\hline
\end{tabular}

FinFEP (Finnish Energy and Forest Policy) model is a dynamic partial equilibrium model covering Finnish forest and energy sectors (Lintunen et al. 2015). In the model, production decisions are optimized by forest industries and energy producers, and harvests are 
optimized by forest owners. Hence, the model describes their responses to policy measures or other exogenous changes and the resulting price impacts through market adjustment. It includes detailed descriptions of Finnish forest resources and their changes through volume increment, natural drain and felling. Data on the current state of forest resources are obtained from the 1oth National Forest Inventory, with five year age-classes in 18 regions of Finland for three tree species and five site classes. Carbon in forest biomass is calculated using biomass expansion factors on growing stock volumes.

ENVIMAT10 is an environmentally extended input-output model of the Finnish economy (Seppälä et al. 2011). The model describes production activity, income, final demand and foreign trade based on the supply and use tables of Statistics Finland. These accounting tables are an integrated part of the SNA in the EU. The monetary input-output tables of ENVIMAT10 are relatively detailed covering 148 industries, 231 products and 7 final use categories. In addition, the model includes material flows, environmental interventions and environmental impacts of the economy.

\subsection{Impact of a new pulp mill on water use}

The hypothetical investment in pulp production results in additional direct freshwater use by roughly 26 million $\mathrm{m}^{3}$. This is roughly $8 \%$ of the estimated current freshwater use in the Finnish Lapland (see Chapter 5.3). How this additional direct water use was distributed across different economic sectors is presented in Table 12. Most of this water would be used by the pulp mill where the investment is made and therefore occurs in Finnish Lapland.

ENVIMAT10 modelling additionally allows analysis of indirect uses of water arising from this investment. (For definition and illustration of direct and indirect water use, see Figure 17 in Chapter 5.5). A pulp mill uses intermediary products from other industries such as raw timber, energy, chemicals, machinery and various services. In the production of these intermediary products, natural resources, such as water, are used. Similarly, each of these industries uses intermediary products from other industries and again, there is water use in varying volumes affiliated with these economic activities. To sum up, water-extended input-output modelling quantifies the total volume of water use along entire chains of production. As illustrated in Table 12, these indirect water use volumes are often comparable in magnitude to the direct water use volumes. This demonstrates that in the environmental assessment of an investment, environmental impacts should be considered and estimated along entire chains of production by using the appropriate modelling tools in the very same manner in which the impacts on labour and value added are estimated. Direct and indirect water emissions can be estimated in a similar manner by using EE-IO modelling. Currently, however, water emission accounts are not available to allow such modelling exercises. 
Table 12: Additional direct and indirect water uses generated in the Finnish economy by an increase in pulp production by 400000 tonnes. SFW $=$ self-abstracted freshwater (excluding freshwater for cooling), MW = mains water, $\mathrm{TW}=$ total water

\begin{tabular}{|c|c|c|c|c|c|c|}
\hline \multirow{2}{*}{ Industry } & \multicolumn{3}{|c|}{ Direct water use $1000 \mathrm{~m}^{3}$} & \multicolumn{3}{|c|}{ Indirect water use $1000 \mathrm{~m}^{3}$} \\
\hline & SFW & MW & TW & SFW & MW & TW \\
\hline Agriculture, aquaculture and forestry & 73.72 & 2.84 & 76.56 & 727 & 6 & 6,442 \\
\hline Mining and quarrying & 14.80 & 0.64 & 15.45 & 267 & 971 & 4,881 \\
\hline Paper and pulp industry & 9,968 & 17.58 & 22,932 & 7,872 & 10,581 & 20,950 \\
\hline Petroleum industry and chemical industry & 2.30 & 5.52 & 2,199 & 879 & 1,875 & 6731 \\
\hline $\begin{array}{l}\text { Basic metal processing, metal and electrical } \\
\text { product and machinery industries }\end{array}$ & 4.11 & 3.98 & 50.94 & 1,333 & 3,112 & 12,502 \\
\hline Other manufacturing industries & 9.32 & 5.83 & 22.79 & 2,784 & 5,317 & 18,270 \\
\hline Energy production & 5.10 & 8.02 & 16,159 & 671 & 1,024 & 2,684 \\
\hline Water supply and sewerage & 0.14 & 13.43 & 1.06 & 350 & 839 & 3,418 \\
\hline $\begin{array}{l}\text { Construction, trade, transportation and } \\
\text { storage }\end{array}$ & 0.03 & 6.62 & 6.73 & 1,077 & 1,979 & 6,794 \\
\hline Other services and public administration & 0.82 & 4.48 & 5.30 & 5,161 & 8,215 & 22,875 \\
\hline Households & 0.13 & 1.15 & 1.28 & 27 & 146 & 856 \\
\hline
\end{tabular}

\subsection{Impact of a new pulp mill on forest asset and on trade-offs between forest based ecosystem services}

\subsubsection{Impact on forest stock and its changes in physical units}

NCA provides a way to report the state and development of the physical amount and monetary value of natural capital. Asset accounts are designed to record information on stocks and changes in stocks of ecosystem assets, including accounting for ecosystem degradation. Physical asset accounts record the opening stock, the additions and reductions to the stock and the closing stock. According to the SEEA Central Framework (United Nations et al. 2014b) guidelines for physical asset accounts, the use of physical asset accounts are suggested for provisioning services and might also be applicable for some regulating services. In Table 13, we present the physical asset account for timber resources in Lapland in the Business as Usual (BAU) scenario, and demonstrate how a new pulp mill would affect the stock in the asset account.

Forest stock is growing rapidly in Finnish Lapland, as shown in development of opening/closing stock over time (Table 13). Additions in stock, i.e. growth of forests, noticeably exceed the reductions in stock, i.e. harvesting and natural losses. However, 
projections for total reductions and additions reveal that removals are increasing rapidly while growth is slowing down over time. Therefore the net increment of forest volume is slowly decreasing.

Physical asset accounts are also well suited for representing the impact of different scenarios or policies on natural capital and explaining the outcome. In this example, the asset account shows that a new pulp mill reduces the forest stock by $5 \%$ at maximum compared to the BAU scenario, and the impact is explained both by an increase in stock reductions in the first periods, as well as, lower timber growth levels. However, depletion does not occur, as the timber stock also grows over time in the PulpMill scenario.

Table 13: Physical asset account for timber resources in Finnish Lapland: BAU levels and differences between PulpMill and BAU scenario, million $\mathrm{m}^{3}$. Additions and reductions are represented for periods of 10 years

\begin{tabular}{|c|c|c|c|c|c|c|c|c|c|c|}
\hline \multirow[b]{2}{*}{ Years after production begins } & \multicolumn{5}{|c|}{ BAU levels } & \multicolumn{5}{|c|}{$\begin{array}{l}\text { Differences between PulpMill and } \\
\text { BAU }\end{array}$} \\
\hline & 0 & 10 & 20 & 30 & 40 & 0 & 10 & 20 & 30 & 40 \\
\hline Opening stock of timber resources & 260 & 318 & 382 & 436 & 482 & 0 & -8.5 & -17.0 & -19.7 & -19.0 \\
\hline Total additions to stock (10 yrs) & 121 & 134 & 140 & 143 & 141 & -0.2 & -0.7 & -1.7 & -1.6 & -0.3 \\
\hline Natural growth & 121 & 134 & 140 & 143 & 141 & -0.2 & -0.7 & -1.7 & -1.6 & -0.3 \\
\hline Total reductions in stock (10 yrs) & 63 & 70 & 86 & 97 & 106 & 8.3 & 7.8 & 1.0 & -2.3 & -1.8 \\
\hline Removals & 46 & 48 & 63 & 74 & 83 & 7.6 & 5.8 & -0.5 & -2.2 & -2.3 \\
\hline Felling residues & 12 & 15 & 15 & 15 & 16 & 0.8 & 2.2 & 1.7 & 0 & 0.4 \\
\hline Natural losses & 5 & 7 & 8 & 8 & 7 & -0.1 & -0.2 & -0.2 & -0.1 & 0 \\
\hline Closing stock of timber resources & 318 & 382 & 436 & 482 & 517 & -8.5 & -17.0 & -19.7 & -19.0 & -17.4 \\
\hline
\end{tabular}

\subsubsection{Impact on forest asset values and trade-offs between ecosystem services}

An ecosystem monetary asset account records the monetary value of opening and closing stocks of ecosystem assets, and additions and reductions in those stocks. The value of an asset is calculated as the net present value of future income flows from ecosystem services, as defined in capital theory (Fischer 1906). In our example, the forest asset value consists of the net present values of two ecosystem services, namely timber production, as provisioning service, and carbon sequestration, as regulating service. The timber income flow consists of incomes from selling timber in the market subtracted by harvesting costs.

The carbon sequestration income flow consists of values of periodical carbon sinks (i.e. carbon stock change) in living biomass with a constant carbon price of 15 or $30 \mathrm{EUR} / \mathrm{t} \mathrm{CO}_{2}$. The timber prices are market prices that are based on forest statistics in the base year of the model, while in later periods they are determined in timber markets described in the model. Harvesting costs are also based on real cost data. 
On the other hand, there are several options to value carbon sequestration. There are several markets for carbon sequestration and carbon emissions, and other valuation methods could also be justified. Our values for carbon sequestration are based on the emission trading market, according to commonly used practices (see e.g., Ovando 2017). The lower carbon price is close to the average price of the EU emission allowance in 2018. Sensitivity of the outcomes to the carbon value is analysed by doubling the value of carbon.

The future flows for timber harvesting and carbon sink are based on the same cutting scenario. This allows us to sum up the values of these two ecosystem services and conduct a trade-off analysis. In Table 14, asset values are represented for the time period when production in the new pulp mill begins.

An asset account with different ecosystem services illustrates their relative values. As seen in Table 14, the importance of different services may differ between regions. In Lapland, the net present value of carbon sink is notable compared to net present value for timber production, even for low carbon price of $15 \mathrm{EUR} / \mathrm{t} \mathrm{CO}_{2}$, and exceeds the net present value for timber production in the case of carbon price of $30 \mathrm{EUR} / \mathrm{t} \mathrm{CO}_{2}$. For the rest of Finland, the timber production is clearly more valuable than carbon sequestration.

Installation of new pulp mill capacity increases the demand of timber. The net present value of timber production increases due to both higher level of cuttings and higher timber prices. Contrastingly, increasing cuttings decreases the carbon sink thus decreasing the net present value of carbon sink. This illustrates the trade-off between timber production and carbon sink. Market impacts are an important part of valuing provisioning services. The impact of a new pulp mill on the value of forest assets is highly dependent on the value used for carbon. With a carbon price of $15 \mathrm{EUR} / \mathrm{t} \mathrm{CO}_{2}$, the increase in net present value of future timber net incomes exceeds the decrease in net present value of carbon sink and thus in total, the value of forest assets increases by 85 million euros in Lapland. For a carbon price of 30 euros, the impact on total asset value is the opposite with the value of forest asset decreasing by 140 million euros.

Table 14: Net present values of forest asset

\begin{tabular}{|c|c|c|c|c|c|}
\hline & Timber production & $\begin{array}{l}\text { Carbon sink } \\
\text { (CP EUR 15) }\end{array}$ & $\begin{array}{l}\text { Carbon sink } \\
\text { (CP EUR 30) }\end{array}$ & $\begin{array}{l}\text { Total asset value } \\
\text { (CP EUR 15) }\end{array}$ & $\begin{array}{l}\text { Total asset value } \\
\text { (CP EUR 30) }\end{array}$ \\
\hline BAU & 5,350 & 3,295 & 6,590 & 8,645 & 11,940 \\
\hline PulpMill & 5,660 & 3,070 & 6,140 & 8,730 & 11,800 \\
\hline Difference & 310 & -225 & -450 & 85 & -140 \\
\hline
\end{tabular}

Note: $\quad$ The total value of the forest asset and its components (the net present values of timber production and the carbon sink as ecosystem services) in Lapland in BAU and PulpMill scenarios, and the difference between these scenarios, in million euros, at carbon prices (CP) of 15 and 30 EUR/t $\mathrm{CO}_{2}$ and a discount rate of $2.7 \%$ 


\subsubsection{Impact on supplies of forest-based ecosystem services}

While asset value consists of the values of flows of ecosystem services over time, supply and use tables provide annual information on the flows of ecosystem services. There is a link between supply tables and asset tables, as supply tables consists of the annual flows needed to calculate net present value in monetary asset accounts or change in stock in physical asset accounts. Supply and use tables provide links between ecosystem type, ecosystem services and economic activities in SNA. The principles of integrating of ecosystem service supply and demand tables into SNA were presented in Chapter 1.3.4.

Table 15 presents the supplies of timber production and carbon sink as ecosystem services both in physical and monetary terms. It differs from the typical supply table suggested in SEEA-EEA guidelines in two respects. First, instead of presenting past levels of supplies of ecosystem services, Table 15 presents the annual impacts of a new pulp mill, thus the figures are differences between the pulp mill scenario and BAU scenario in a given year. Second, instead of having a supply table for several ecosystem types for one moment of time, we present the figures for several years for one ecosystem type.

Trade-off between timber production and carbon sink is clearly also seen in the annual supplies of these ecosystem services (Table 15). Interestingly, trade-offs does not appear in all periods, as seen in the case of 25 years after production begins. This is due to the age structure of the forest. Table 15 illustrates that the impacts of economic actions like investments or policies may not be constant over time. In this case, impacts are diminishing as the impact of investment on the production level diminishes over time.

Table 15: Impact of new pulp mill on annual supplies of timber production and carbon sink in physical (million $\mathrm{m}^{3} /$ million tonnes of $\mathrm{CO}_{2}$ ) and monetary units (million euros, for carbon price of $15 \mathrm{EUR} / \mathrm{t} \mathrm{CO}_{2}$ ) in Finnish Lapland for 0-30 years after production in new pulp mill begins

\begin{tabular}{|c|c|c|c|c|c|c|c|}
\hline \multirow[b]{2}{*}{ Years after production begins } & \multicolumn{7}{|c|}{ Ecosystem type: Tree-covered areas } \\
\hline & 0 & 5 & 10 & 15 & 20 & 25 & 30 \\
\hline \multicolumn{8}{|l|}{ Physical units } \\
\hline Timber, million $\mathrm{m}^{3}$ & 1.0 & 0.6 & 0.5 & 0.7 & 0.1 & -0.2 & -0.3 \\
\hline Carbon sink, million $\mathrm{tCO}_{2}$ & -1.3 & -0.9 & -0.8 & -1.2 & -0.4 & -0.2 & 0.2 \\
\hline \multicolumn{8}{|l|}{ Monetary units } \\
\hline Timber, million euros & 38 & 20 & 19 & 24 & 1 & -5 & -9 \\
\hline Carbon sink, million euros & -20 & -13 & -13 & -18 & -7 & -2 & 2 \\
\hline
\end{tabular}




\subsubsection{Impact on forest asset value in other regions}

The impacts of a new pulp mill are not restricted to the region in which the production takes place. Indeed, in our case study, the impacts on forest asset value and net present values of ecosystem services examined were larger in the rest of Finland than in Finnish Lapland. The loss in net present value of carbon sink is EUR 415 million with carbon price of $15 \mathrm{EUR} / \mathrm{t} \mathrm{CO}_{2}$ while in Lapland the impact is EUR 225 million (Table 16). The negative environmental impact in the rest of Finland is explained by the increased cuttings as Lapland had to import timber from other regions to satisfy the increased demand due to the new pulp mill. The larger cuttings decrease the value of carbon sink. However, the value of timber production increases even more. The value of timber production increases by 730 million euros due to increases in both quantity and prices of timber. In addition to the increased value of imported timber, the higher timber prices also apply to timber sales in the rest of Finland.

Table 16: The total value of the forest asset and its components (the net present values of timber production and the carbon sink as ecosystem services) in the rest of Finland in BAU and PulpMill scenarios, and the difference between these scenarios, in million euros, at carbon prices (CP) of 15 and $30 \mathrm{EUR} / \mathrm{t} \mathrm{CO} 2$ and a discount rate of $2.7 \%$

\begin{tabular}{ll|l|l|l} 
Timber production & $\begin{array}{l}\text { Carbon sink } \\
\text { (CP EUR 15) }\end{array}$ & $\begin{array}{l}\text { Carbon sink } \\
\text { (CP EUR 30) }\end{array}$ & $\begin{array}{l}\text { Total asset value } \\
\text { (CP EUR 15) }\end{array}$ & $\begin{array}{l}\text { Total asset value } \\
\text { (CP EUR 30) }\end{array}$
\end{tabular}

$\begin{array}{lrrrrr}\text { Rest of Finland } & & & & \\ \text { BAU } & 91,150 & 13,585 & 27,175 & 104,735 & 118,325 \\ \text { PulpMill } & 91,880 & 13,170 & 26,345 & 105,050 & 118,225 \\ \text { Difference } & 730 & -415 & -830 & 315 & -100 \\ & & & & & \\ \text { Lapland } & & & & & \\ \text { BAU } & & & & & 11,940 \\ \text { PulpMill } & 5,350 & 3,295 & 6,590 & 8,645 & 11,800 \\ \text { Difference } & 5,660 & 3,070 & 6,140 & 8,730 & -140 \\ & 310 & -225 & -450 & 85 & \\ \end{array}$

Note: $\quad$ Figures for Lapland are from Table 14 and presented here for comparison.

\subsection{Trade-offs between environmental and economy-wide impacts in monetary and physical units due to the new pulp mill}

In this sub-chapter, we focus on the whole economy and combine systems of SNA and NCA in the assessment of the impacts of new pulp mill for Finland. Economy-wide impacts are assessed with GDP and employment.

The new pulp mill increases the gross value added (GDP) by EUR 150 million annually compared to BAU, according to ENVIMAT10 calculations (Table 17). Half of the impact took place in the forest industry, while the other half is due to the indirect impacts as goods produced in other manufacturing and service industries are used as inputs in the forest industry. This economic benefit would be typically reported in 
assessing the impacts of a new pulp mill with an economy-wide model. The additional information from NCA however reveals that the value of environmental losses from lower carbon sequestration is notable. The analysis also illustrates the trade-off between economic and environmental benefits due to the new pulp mill.

Table 17: Annual impact of a new pulp mill on gross value added and value of carbon sink in Finland when production begins

Values

Note: Loss in value of carbon sink is not directly comparable with increase in gross value added.

In many cases, values for ecosystem services are not available or are not reliable. It is however possible to present economic and environmental impacts and illustrate trade-offs in physical or other non-monetary units, as seen in Table 18. The economic benefits of the new pulp mill include the increased amount of pulp, as well as, improved employment. Additional production, however, increases the use of natural resources, as seen in increased harvests and freshwater use. Increase in harvests decreases the amount of carbon sink thus weakening the mitigation of climate change. Higher use of freshwater has also negative impacts on the environment due to pollution loading to the water.

Table 18: Annual impact of new pulp mill on the use of several resources and ecosystem services in Finland when production begins

\section{Resource}

Pulp, tonnes

$+400,000$

Employment, total, persons

$+1,700$

Employment, forest sector, persons

$+600$

Harvests, million $\mathrm{m}^{3}$

$+2.0$

Use of freshwater, million $\mathrm{m}^{3}$

$+26.2$

Carbon sink, million $\mathrm{t} \mathrm{CO}_{2}$

As shown in the above illustrations, economic-ecological modelling combined with the NCA framework is a useful tool to provide information on both economic and environmental impacts of different scenarios or policies. This information can be utilized in decision-making of different agents. In our example, we showed the negative impact on carbon sink due to a new pulp mill. Currently, this impact is not taken into account by private investors because there is no policy instrument to provide incentive to increase carbon sequestration that would be reflected in timber prices for investors. By making 
environmental impacts explicit, NCA can help realize the need for regulation. In addition, the information of negative impacts might affect consumption decisions by worsening product images. In the case of increased use of water and pollution loading, the information from NCA could affect the environmental permit process. 


\section{Abbreviations}

\begin{tabular}{|c|c|}
\hline ANS & Adjusted Net Saving \\
\hline BAU & Business as Usual \\
\hline CP & Carbon prices \\
\hline EE-IO & Environmentally-extended input-output \\
\hline EIA & Environmental Impact Assessment \\
\hline ELY Centres & Centres for Economic Development, Transport and the Environment \\
\hline ENVIMAT10 & Environmentally-extended input-output model for the Finnish economy \\
\hline $\mathrm{EC}$ & European Commission \\
\hline EEC & European Environmental Commission \\
\hline EU & European Union \\
\hline FinFEP & Finnish Energy and Forest Policy model \\
\hline GDP & Gross Domestic Product \\
\hline NACE & $\begin{array}{l}\text { Statistical Classification of Economic Activities in the European } \\
\text { Community }\end{array}$ \\
\hline NCA & Natural Capital Accounting \\
\hline NIER & National Institute for Economic Research (Sweden) \\
\hline OECD & Organisation for Economic Co-operation and Development \\
\hline RBD & River basin district \\
\hline SDGs & Sustainable Development Goals \\
\hline SEEA & System for Environmental and Economic Accounts \\
\hline SEEA-CF & Central Framework \\
\hline SEEA-EEA & SEEA Experimental Ecosystem Accounts \\
\hline SNA & System of National Accounts \\
\hline SYKE & Finnish Environment institute \\
\hline UN & United Nations \\
\hline UNU-IHDP & $\begin{array}{l}\text { UN University - International Human Dimensions Programme on Global } \\
\text { Environmental Change }\end{array}$ \\
\hline WAVES & Wealth Accounting and the Valuation of Ecosystem Services \\
\hline WFD & Water Framework Directive \\
\hline WISE SoE & Water Information System for Europe State of the Environment \\
\hline WTP & Willingness to pay \\
\hline
\end{tabular}




\section{References}

Aaltonen, J., L. Ahopelto, T. Dubrovin, T. Hjerppe, J. Kallio, V. Lehtoranta, M. Maunula, M. Puustinen, and S. Väisänen. 2016. Vesivarojen arvo Suomessa [Value of water resources in Finland]. Report 23, Finnish Environmental Institute.

Árnason, R. 2017. Efficient pricing of tourist sites. Research in applied business and economics 14:133-150. doi: https://doi.org/10.24122/tve.a.2017.14.1.6

Artell, J. 2014. Lots of value? A spatial hedonic approach to water quality valuation. Journal of Environmental Planning and Management 57:862-882. doi: https://doi.org/10.1080/og640568.2013.772504

Asheim, G. B. and M. L. Weitzman. 2001. Does NNP growth indicate welfare improvement? Economics Letters 73:233-239. doi: https://doi.org/10.1016/S0165-1765(01)00493-1

Bache, I. and M. Flinders, editors. 2004. Multi-level Governance. Oxford University Press. doi: https://doi.org/10.1093/0199259259.001.0001

Bartelmus, P. 2014. Environmental-economic accounting: Progress and digression in the SEEA revisions. Review of Income and Wealth 6o:887-904. doi: https://doi.org/10.1111/roiw.12056

Bartelmus, P., C. Stahmer, and J. Vantongeren. 1991. Integrated Environmental and Economic Accounting - Framework for a SNA Satellite System. Review of Income and Wealth:111-148. doi: https://doi.org/10.1111/j.1475-4991.1991.tboo350.x

Barton, D. N., H. Lindhjem, K. Magnussen, and S. Holen. 2012a. Valuation of Ecosystem Services From Nordic Watersheds - From Awareness Raising to Policy Support? (VALUESHED). Nordic Council of Ministers, Oslo, Norway. doi: https://doi.org/10.6027/tn2012-506

Barton, D. N., H. Lindhjem, K. Magnussen, S. Norge, and S. Holen. 2012b. Valuation of Ecosystem Services from Nordic Watersheds - From awareness raising to policy support? (VALUESHED). TemaNord 2012:506, Nordic Council of Ministers. doi: https://doi.org/10.6027/tn2012-506

Björk, O., V. Palm, N. Steinbach, Ø. Lone, K. Kolshus, O. G. Pedersen, S. Krarup, L. Kolttola, and A. Lindblom. 2016. Making the environment count - Nordic accounts and indicators for analysing and integrating environment and economy. TemaNord 2016:507, Nordic Council of Ministers. doi: https://doi.org/10.6027/TN2016-507

Björnsson, H., B. D. Sigurðsson, B. Davíðsdóttir, J. Ólafsson, Ó. S. Ástthorsson, S. Ólafsdóttir, T. Baldursson, and T. Jónsson. 2018. Loftslagsbreytingar og áhrif peirra á Íslandi - Skýrsla vísindanefndar um loftslagsbreytingar 2018 [Climate changes and their impact in Iceland Report of the science committee on climate changes 2018]. Icelandic Meteorological Office.

Blackstock, K. L. and C. E. Carter. 2007. Operationalising sustainability science for a sustainability directive? Reflecting on three pilot projects. Geographical Journal 173:343-357. doi: https://doi.org/10.1111/j.1475-4959.2007.00258.x

Bourblanc, M., A. Crabbé, D. Liefferink, and M. Wiering. 2013. The marathon of the hare and the tortoise: implementing the EU Water Framework Directive. Journal of Environmental Planning and Management 56:1449-1467. doi: https://doi.org/10.108o/og640568.2012.726197

Boyes, S. J. and M. Elliott. 2014. Marine legislation - The ultimate 'horrendogram': International law, European directives \& national implementation. Marine Pollution Bulletin 86:39-47. doi: https://doi.org/10.1016/j.marpolbul.2014.06.055

Burns, T. R. and H. Flam. 1987. The shaping of social organization: social rule system theory with applications. Sage Publications, London.

CAFF. 2013. Arctic Biodiversity Assessment: Status and Trends in Arctic Biodiversity. Conservation of Arctic Flora and Fauna, Akureyri. 
Caparrós, A., J. L. Oviedo, A. Álvarez, and P. Campos. 2017. Simulated exchange values and ecosystem accounting: Theory and application to free access recreation. Ecological Economics 139:140-149. doi: https://doi.org/10.1016/j.ecolecon.2017.04.011

Carson, M., T. Burns, and D. Calvo, editors. 2009. Paradigms in public policy: Theory and practice of paradigm shifts in the EU. Peter Lang.

Chave, P. 2001. The EU Water Framework Directive. IWA Publishing.

CliC/AMAP/IASC. 2016. The Arctic Freshwater System in a Changing Climate. WCRP Climate and Cryosphere (CliC) Project, Arctic Monitoring and Assessment Programme (AMAP), International Arctic Science Committee (IASC). https://www.amap.no/documents/doc/thearctic-freshwater-system-in-a-changing-climate/1375

Commission on Sustainable Development. 2016. The Finland we want by 2050 - Society's Commitment to Sustainable Development https://kestavakehitys.fi/sitoumus2050

Commission on Sustainable Development. 2017. Kestävän kehityksen kansallisen seuranta- ja arviointijärjestelmän kuvaus [Description of the national monitoring and evaluation system for sustainable development]. Kestävän kehityksen toimikunnan kokoukselle 9.5.2017 [Meeting of the Commission on Sustainable Development on 9.5.2017].

Costanza, R., R. dArge, R. deGroot, S. Farber, M. Grasso, B. Hannon, K. Limburg, S. Naeem, R. V. Oneill, J. Paruelo, R. G. Raskin, P. Sutton, and M. vandenBelt. 1997. The value of the world's ecosystem services and natural capital. Nature 387:253-260. doi: https://doi.org/10.1038/387253ao

Dasgupta, P. and K. G. Mäler. 2000. Net national product, wealth, and social well-being. Environment and Development Economics 5:69-93. doi: https://doi.org/10.1017/S1355770Xoooooo61

Davíðsdóttir, B. 2010. Ecosystem services and human-wellbeing: the value of ecosystem services.in D. M. Kristófersson, editor. Rannsóknir í Félagsvísindum XI: Hagfræðideild. The Social Science Research Institute, Reykjavík. http://hdl.handle.net/1946/6775

Droste, N. and B. Bartkowski. 2018. Ecosystem Service Valuation for National Accounting: A Reply to Obst, Hein and Edens (2016). Environmental and Resource Economics 71:205-215. doi: https://doi.org/10.1007/s10640-017-0146-3

Eckerberg, K., A. Zachrisson, and G. Mårald. 2012. Samverkan i Bottenvikens vattendistrikt: analys av vattenrådsarbetet. [Collaboration in the Bothnia Bay water district: analysis of water management]. No. 6/2012, County Administrative Board of Norrbotten, Luleå.

Egilson, D. 2016. Greining á grunnvatnsmælingum á pjórsár- og Tungnaársvæði 2015 [Analysis on groundwater measurements in Thjorsá- and Tungá Rivers in 2015]. Report VI 2016-002 / LV 2016-038, Icelandic Meteorological Office, Reykjavík. http://www.vedur.is/media/vedurstofanutgafa-2016/VI_2016-002.pdf

Egilson, D. and G. Stefánsdóttir. 2014. Álagspættir á grunnvatn. [Groundwater pressures]. DE/GSt-2014-001, Icelandic Meteorological Office. http://www.vedur.is/media/vedurstofanutgafa-2016/VI_2016-002.pdf

Einarsson, Á., G. Stefánsdóttir, H. Jóhannesson, J. S. Ólafsson, G. Már Gíslason, I. Wakana, G. Gudbergsson, and A. Gardarsson. 2004. The ecology of Lake Myvatn and the River Laxá: Variation in space and time. Aquatic Ecology 38:317-348. doi: https://doi.org/10.1023/B:AECO.0000032090.72702.a9

Eiríksdóttir, E. S. 2016. Weathering and riverine fluxes in pristine and controlled river catchments. PhD dissertation. Faculty of Earth Sciences, University of Iceland. http://hdl.handle.net/1946/23831

Elliott, M. 2014. Integrated marine science and management: Wading through the morass. Marine Pollution Bulletin 86:1-4. doi: https://doi.org/10.1016/j.marpolbul.2014.07.026

Emmelin, L. 1998a. Ealuating nordic environmental impact assessment - part 2: Professional culture as an aid in understanding implementation. Scandinavian Housing and Planning Research 15:187-209. doi: https://doi.org/10.1080/02815739808730457 
Emmelin, L. 1998b. Evaluating environmental impact assessment systems - part 1: Theoretical and methodological considerations. Scandinavian Housing and Planning Research 15:129-148. doi: https://doi.org/10.1080/02815739808730452

Environmental Agency Iceland. 2018. Friðland að Fjallabaki. [Fjallabaki Nature Reserve] https://www.ust.is/einstaklingar/nattura/fridlyst-svaedi/sudurland/fridland-ad-fjallabaki/\#Tab4

European Commission. 1992. Habitats Directive. 92/43/EEC. https://eur-lex.europa.eu/legalcontent/en/TXT/?uri=CELEX\%3A31992Loo43

European Commission. 2000. Water Framework Directive. 2000/60/EC. https://eurlex.europa.eu/legal-content/EN/TXT/?uri=CELEX:3200oLoo6o

European Commission. 2009. Birds Directive. 2009/147/EC. https://eur-lex.europa.eu/legalcontent/EN/TXT/?uri=CELEX\%3A32009L0147

European Commission. 2011. Our life insurance, our natural capital: an EU biodiversity strategy to 2020 . $\operatorname{COM}(2011) 244$.

European Commission. 2013. European System of Accounts: ESA 2010. doi: 10.2785/16644

Eurostat. 2008. NACE Rev. 2: Statistical Classification of Economic Activities in the European Community. European Commission. https://publications.europa.eu/en/publication-detail//publication/5a6of718-2boe-11e7-9412-01aa75ed71a1

Fu, B. J., C. H. Su, Y. P. Wei, I. R. Willett, Y. H. Lü, and G. H. Liu. 2011. Double counting in ecosystem services valuation: Causes and countermeasures. Ecological Research 26:1-14. doi: https://doi.org/10.1007/s11284-010-0766-3

Gravgård, O., editor. 2018. Green National Accounts for Denmark 2015-2016: Highlighting the link between the economy and the environment through environmental-economic accounting. Statistics Denmark. https://www.dst.dk/en/Statistik/Publikationer/VisPub?cid=27468

Gudbrandsson, G. I. 2017. Ferðamenn og umhverfisáhrif [Tourists and Environmental Impact]. Vísir. http://www.visir.is/g/2017170118826

Halleraker, J. H., L. Sorby, A. Keto, and H. Gudmundsdóttir, editors. 2013. Nordic Collaboration on Implementation of the Water Framework Directive - Status and Further Challenges. Umhverfisstofnun, Reykjavík. http://hdl.handle.net/10802/2774

Hanley, N., R. E. Wright, and B. Alvarez-Farizo. 2006. Estimating the economic value of improvements in river ecology using choice experiments: an application to the water framework directive. Journal of Environmental Management 78:183-193. doi: https://doi.org/10.1016/j.jenvman.2005.05.001

Hardardóttir, J. and S. Zophoníasson. In press. Glacier rivers in Iceland, discharge and sediment transport.

Hartwick, J. M. 1990. Natural resources, national accounting and economic depreciation. Journal of Public Economics 43:291-304. doi: https://doi.org/10.1016/0047-2727(90)90002-Y

Hasler, B., T. Lundhede, L. Martinsen, S. Neye, and J. S. Schou. 2005. Valuation of groundwater protection versus water treatment in Denmark by Choice Experiments and Contingent Valuation.

Hasselstrom, L. and C. Hakansson. 2014. Detailed vs. fuzzy information in non-market valuation studies: the role of familiarity. Journal of Environmental Planning and Management 57:123143. doi: https://doi.org/10.1080/09640568.2012.736370

Heal, G. and B. Kristrom. 2005. National Income and the Environment.in K. G. Maler and J. R. Vincent, editors. Handbook of Environmental Economics. Elsevier B.V.

Hein, L., C. Obst, B. Edens, and R. P. Remme. 2015. Progress and challenges in the development of ecosystem accounting as a tool to analyse ecosystem capital. Current Opinion in Environmental Sustainability 14:86-92. doi: https://doi.org/10.1016/j.cosust.2015.04.002

Hein, L., K. van Koppen, R. S. de Groot, and E. C. van lerland. 2006. Spatial scales, stakeholders and the valuation of ecosystem services. Ecological Economics 57:209-228. doi:

https://doi.org/10.1016/j.ecolecon.2005.04.005 
Hjaltason, S. E., M. Guðmundsdóttir, J. Á. Haukdal, and J. R. Gudmundsson. 2018. Energy statistics 2017. National Energy Authority. https://orkustofnun.is/gogn/os-onnur-rit/Orkutolur2017-enska-A4.pdf

Hojem, P. 2015. Mining in the Nordic countries: A comparative review of legislation and taxation. TemaNord 2015:542, Nordic Council of Ministers. doi: https://doi.org/10.6027/TN2015-542

Hollingsworth, J. R., K. H. Müller, and E. J. Hollingsworth, editors. 2002. Advancing socioeconomics: An institutionalist perspective. Rowman \& Littlefield, Lanham.

Icelandic Meteorological Office. Map of annual mean precipitation in Iceland. http://www.vedur.is/vedur/vedurfar/kort/medalurkoma_a/

Icelandic Meteorological Office. 2018. Nytjavatns vefsjá [Water usage web site]. http://nytjavatn.vedur.is

Icelandic Tourist Board. 2016. International visitors in Iceland, summer 2016. https://www.ferdamalastofa.is/static/files/ferdamalastofa/Frettamyndir/2017/januar/sunarkonnu n/sumar-2016-islensk.pdf

Icelandic Tourist Board. 2018a. Áætlaður fjöldi á svæðum og stöðum. [Estimated numbers by region and location]. https://www.ferdamalastofa.is/is/tolur-og-utgafur/fjoldiferdamanna/aaetladur-fjoldi-a-svaedum-og-stodum

Icelandic Tourist Board. 2018b. Foreign visitors to Iceland 1949-2017. https://www.ferdamalastofa.is/static/files/ferdamalastofa/Frettamyndir/2018/mai/foreignvisitors-to-iceland-1949-2017.xls

Icelandic Travel Association. 2012. Umsögn Ferðafélag íslands vegna tillögu að landsskipulagsstefnu 2013-2024. [Review of the ITA on proposed National Planning Strategy 2013-2024]. http://www.landsskipulag.is/media/lskathugasemdirumsagnir/Ferdafelag_Islands.pdf

IPCC. 2018. Special Report on Global Warming of $1.5^{\circ} \mathrm{C}$. SR15. http://www.ipcc.ch/report/sr15/

Jensen, E. H., D. Egilson, S. B. Thorláksdóttir, S. Zóphóníasson, S. P. Snorrason, I. Jónsdóttir, M. Á. Jónsson, and M. J. Roberts. 2018. Hættumat vegna jökulhlaupa í Skaftá: Set í hlaupi haustið 2015 [Hazard assessment of jökulhlaup in Skaftá: Sediment in jökulhlaup in the fall 2015]. Report. VÍ 2018-006.

Jóhannesdóttir, H. M. 2010. Economic valuation of ecosystem services: the case of lake Elliðavatn and lake Vífilsstaðavatn.in D. M. Kristófersson, editor. Rannsóknir í Félagsvísindum XI: Hagfræðideild. The Social Science Research Institute, Reykjavík. http://hdl.handle.net/1946/6728

Jónsdóttir, J. F. 2008. A runoff map based on numerically simulated precipitation and a projection of future runoff in Iceland. Hydrological Sciences Journal 53:100-111. doi: https://doi.org/10.1623/hysj.53.1.100

Jorgensen, S. L., S. B. Olsen, J. Ladenburg, L. Martinsen, S. R. Svenningsen, and B. Hasler. 2013. Spatially induced disparities in users' and non-users' WTP for water quality improvementsTesting the effect of multiple substitutes and distance decay. Ecological Economics 92:58-66. doi: https://doi.org/10.1016/j.ecolecon.2012.07.015

Kallis, G. and D. Butler. 2001. The EU water framework directive: measures and implications. Water Policy 3:125-142. doi: https://doi.org/10.1016/S1366-7017(01)00007-1

Kataria, M. 2009. Willingness to pay for environmental improvements in hydropower regulated rivers. Energy Economics 31:69-76. doi: https://doi.org/10.1016/j.eneco.2008.07.005

Keskitalo, E. C. H. and M. Pettersson. 2012. Implementing Multi-level Governance? The Legal Basis and Implementation of the EU Water Framework Directive for Forestry in Sweden. Environmental Policy and Governance 22:90-103. doi: https://doi.org/10.1002/eet.1574

Keto, A., M. Mäenpää, J. H. Halleraker, L. Fjellv, and J. Kling. 2014. How to improve resource effective implementation of WFD in Nordic countries, Confrence report. SYKE. http://www.syke.fi/download/noname/\%7B94D2C128-2EA1-47EC-9B3D$583{ }_{3} 681 B^{2}{ }_{512} \% 7 \mathrm{D} / 106740$ 
Kettunen, M., P. Vihervaara, S. Kinnunen, D. D'Amato, T. Badura, M. Argimon, and P. ten Brink. 2012. Socio-economic importance of ecosystem services in the Nordic Countries - Synthesis in the context of The Economics of Ecosystems and Biodiversity (TEEB). TemaNord 2012:559, Nordic Council of Ministers. doi: https://doi.org/10.6027/TN2012-559

Koskela, S., I. Mäenpää, J. Seppälä, T. Mattila, and M.-R. Korhonen. 2011. EE-IO modeling of the environmental impacts of Finnish imports using different data sources. Ecological Economics 70:2341-2349. doi: https://doi.org/10.1016/j.ecolecon.2011.07.012

Kristmannsdóttir, H., Á. E. Sveinbjörnsdóttir, and J. Heinemeier. 2007. Evolution and origin of geothermal waters in Öxarfjörur, NE Iceland. Pages 223-227 in T. D. Bullen and Y. Wang, editors. Water-Rock Interaction: Proceedings of the 12th International Symposium on WaterRock Interaction. Taylor \& Francis, London. doi: https://doi.org/10.1201/NOE0415451369.ch44

Kristofersson, D. M. 2014. Hvers virđi er náttúran? Sjónarhorn hagfræđinnar. [What is the value of nature? Economic viewpoint]. https://www.umhverfisraduneyti.is/media/PDF_skrar/DadiMar.pptx

Kristófersson, D. M. and K. Eiríksdottir. 2010. Valuing recreational demand. The case of Heiðmörk.in D. M. Kristófersson, editor. Rannsóknir í Félagsvísindum XI: Hagfræðideild. The Social Science Research Institute, Reykjavík. http://hdl.handle.net/1946/6775

Kumar, R., R. J. McInnes, M. Everard, R. C. Gardner, K. A. A. Kulindwa, H. Wittmer, and D. Infante Mata. 2017. Integrating multiple wetland values into decision-making. Ramsar Policy Brief No. 2, Ramsar Convention Secretariat, Gland, Switzerland.

La Notte, A. and S. Dalmazzone. 2018. Sustainability assessment and causality nexus through ecosystem service accounting: The case of water purification in Europe. Journal of Environmental Management 223.

La Notte, A., J. Maes, S. Dalmazzone, N. D. Crossman, B. Grizzetti, and G. Bidoglio. 2017. Physical and monetary ecosystem service accounts for Europe: A case study for in-stream nitrogen retention. Ecosystem Services 23:18-29. doi:

https://doi.org/10.1016/j.ecoser.2016.11.002

Lai, T. Y., J. Salminen, J. P. Jappinen, S. Koljonen, L. Mononen, E. Nieminen, P. Vihervaara, and S. Oinonen. 2018. Bridging the gap between ecosystem service indicators and ecosystem accounting in Finland. Ecological Modelling 377:51-65. doi:

https://doi.org/10.1016/j.ecolmodel.2018.03.006

Launiainen, S., M. N. Futter, D. Ellison, N. Clarke, L. Finér, L. Högbom, A. Laurén, and E. Ring. 2014. Is the Water Footprint an Appropriate Tool for Forestry and Forest Products: The Fennoscandian Case AMBIO 43:244-256 doi: 10.1007/s13280-013-0380-Z

Lehtoranta, V., T. Hjerppe, J. Kotanen, and S. Oinonen. unpublished. Comparing and transferring River Basin level benefit and cost information. doi: https://doi.org/10.1007/s13280013-0380-Z

Leskinen, P., A. Holma, K. Manninen, T. Sinkko, K. Pasanen, M. Rantala, and L. Sokka. 2014. Uusiutuvan energian tuotannon ja käytön ympäristövaikutukset ja -riskit. [Environmental impacts and risks of renewable energy production]. Ympäristöministeriön raportteja 9/2014, Ministry of the Environment, Helsinki. http://hdl.handle.net/10138/44838

Lintunen, J., J. Laturi, and J. Uusivuori. 2015. Finnish Forest and Energy Policy Model (FinFEP): A model description. Natural resources and bioeconomy studies 59/2015, Luke.

Magnussen, K., B. Hasler, and M. Zandersen. 2014. Ecosystem Services - In Nordic Freshwater Management. TemaNord 2014:561, Nordic Council of Ministers. doi: https://doi.org/10.6027/TN2014-561

Mazza, L., M. Bröckl, S. Ahvenharju, P. ten Brink, and T. Pursula. 2013. Nordic Capital in a Nordic Context - Status and Challenges in the Decade of Biodiversity. Nordic Council of Ministers. doi: https://doi.org/10.6027/TN2013-526

Meriläinen, P., J. Salminen, R. Britschgi, T. Nystén, and T. Pitkänen. 2017. Esiselvitys yhdyskuntien ja ruoantuotannon veden käytön riskien hallinnasta ja mahdollisuuksista [Preliminary study of risk management and opportunities associated with municipalities and 
food production]. 32/2017, Terveyden ja hyvinvoinnin laitos, Helsinki.

http://urn.fi/URN:ISBN:978-952-302-911-8

Millennium Ecosystem Assessment. 2005. Ecosystems and Human Well-Being. Washington,

D.C. https://www.millenniumassessment.org/en/index.html

Mitikka, S., P. Räinä, and A. Puro-Tahvanainen. 2017. Suomen arktisten vesien tila [The state of Finnish Arctic waters]. Vesitalous 5/2017

Muukkonen, J. 2003. Water accounts: The project on water accounts by branches of industry. Statistics Finland.

National Energy Authority. 2018. Vatnsorka [Hydropower]. https://orkustofnun.is/vatn/vatnsafl/

National Planning Agency. 2014. Landsskipulagsstefna 2015-2026 [Regional Planning Policy 2015-2026]. http://www.landsskipulag.is/media/pdf-skjol/Landsskipulagsstefna20152026_asamt_greinargerd.pdf

National Planning Agency. 2018. Pjónustumiðstöð í Landmannalaugum: Ákvörðun um matsskyldu. [Landmannalaugar Service Center: Decision on EIA]. 201702019.

http://www.skipulag.is/media/attachments/Umhverfismat/1263/Landmannalaugar\%20\% ${ }_{3} \% \mathrm{~A}_{1}$ kv\%C3\%B6r\%C3\%Boun\%2oum\%2omatsskyldu.pdf

National Research Council. 1999. Nature's Numbers: Expanding the National Economic Accounts to Include the Environment. The National Academies Press., Washington, DC. doi: https://doi.org/10.17226/6374

Niemi, J. 2010. Water quality of arctic rivers in Finnish Lapland. Environmental Monitoring and Assessment 161:359-368. doi: https://doi.org/10.1007/s10661-009-0753-8

Nilsson, M., T. Zamparutti, J. E. Petersen, B. Nykvist, P. Rudberg, and J. McGuinn. 2012. Understanding Policy Coherence: Analytical Framework and Examples of Sector-Environment Policy Interactions in the EU. Environmental Policy and Governance 22:395-423. doi: https://doi.org/10.1002/eet.1589

Nordhaus, W. D. 2006. Principles of National Accounting For Nonmarket Accounts.in D. W. Jorgenson, J. S. Landefeld, and W. D. Nordhaus, editors. A New Architecture for the U.S. National Accounts. University of Chicago Press. doi: https://doi.org/10.7208/chicago/9780226410876.003.0004

Obst, C., L. Hein, and B. Edens. 2016. National Accounting and the Valuation of Ecosystem Assets and Their Services. Environmental and Resource Economics 64. doi: https://doi.org/10.1007/s10640-015-9921-1

Ojea, E., J. Martin-Ortega, and A. Chiabai. 2012. Defining and classifying ecosystem services for economic valuation: The case of forest water services. Environmental Science and Policy 1920:1-15. doi: https://doi.org/10.1016/j.envsci.2012.02.002

Ólafsson, R. and G. Thorhallsdottir. 2018. Dreifing ferðamanna um landið. Talningar ferðamanna á áfangastöðum út árið 2017. [Dispersal of tourists around the country. Tourist counting at destination sites throughout 2017]. RMF-S-10-2018, Icelandic Tourism Research Centre. https://www.ferdamalastofa.is/static/research/files/talning_ferdamanna_2018pdf

Ostrom, E. and M. A. Janssen. 2005. Multi-Level Governance and Resilience of Social-Ecological Systems. Pages 239-259 in M. Spoor, editor. Globalisation, Poverty and Conflict: A Critical "Development" Reader. Springer Netherlands, Dordrecht. doi: https://doi.org/10.1007/1-40202858-X_13

Ovando, P., Caparrós, A., Diaz-Balteiro, L., Pasalodos, M., Beguería, S., Oviedo, J. L., Montero, G. \& Campos, P. 2017. Spatial valuation of forests' environmental assets: an application to Andalusian silvopastoral farms. Land Economics 93:87-108. doi: https://doi.org/10.3368/le.93.1.87

Pfister, S., A. Koehler, and S. Hellweg. 2009. Assessing the Environmental Impacts of Freshwater Consumption in LCA. Environmental Science \& Technology 43:4098-4104. doi: https://doi.org/10.1021/es802423e

Pokki, H., J. Artell, J. Mikkola, P. Orell, and V. Ovaskainen. 2018. Valuing recreational salmon fishing at a remote site in Finland: A travel cost analysis. Fisheries Research 208:145-156. doi: https://doi.org/10.1016/j.fishres.2018.07.013 
Prowse, T., A. Bring, J. Mard, and E. Carmack. 2015. Arctic freshwater synthesis: Introduction. Journal of Geophysical Research-Biogeosciences 120:2121-2131. doi:

https://doi.org/10.1002/2015JG003127

Registers Iceland. 2012. Extracted from public registration [dataset].

Reynisdóttir, H. H. and G. P. Jóhannesson. 2016. „Pað má eitt fjall vera ósnortið fyrir pessum andskotans túristum": Umhverfisstjórnun, náttúrutengsl og ferðamennska ["At least one mountain should be unspoiled by the damn tourists": Environmental management, nature connection and tourism]. Íslenska pjóðfélagið 17.

http://www.thjodfelagid.is/index.php/Th/article/view/10o

Salminen, J. M., P. J. Veiste, J. T. Koskiaho, and S. Tikkanen. 2018. Improving data quality, applicability and transparency of national water accounts - A case study for Finland. Water Resources and Economics 24:25-39. doi: https://doi.org/10.1016/j.wre.2018.05.001

Salter, I., K. Hendriksen, S. Hirsbak, and J. Laitakari. 2003. Towards a Sustainable arctic Tourism: An integrated strategy for the sustainable development of tourism in the Nordic Arctic. Nordic Council of Ministers.

http://orbit.dtu.dk/files/103045178/Towards_a_Sustainable_Arctic_Tourism.pdf

Sarkki, S., L. Rantala, and P. Karjalainen Timo. 2015. Fit between Conservation Instruments and Local Social Systems: Cases of Co-management and Payments for Ecosystem Services. Change and Adaptation in Socio-Ecological Systems. doi: https://doi.org/10.1515/cass-20150007

Seppälä, J., I. Mäenpää, S. Koskela, T. Mattila, A. Nissinen, J.-M. Katajajuuri, T. Härmä, M.-R. Korhonen, M. Saarinen, and Y. Virtanen. 2011. An assessment of greenhouse gas emissions and material flows caused by the Finnish economy using the ENVIMAT model. Journal of Cleaner Production 19:1833-1841. doi: https://doi.org/10.1016/j.jclepro.2011.04.021

Sigurðardóttir, H. E. and D. M. Krisofersson. 2010. Verðmætamat á neysluvatnsauðlindinni í Heiðmörk [Value of the drinking water resources in Heiðmörk].in D. M. Kristófersson, editor. Rannsóknir i Félagsvísindum XI: Hagfræðideild. The Social Science Research Institute, Reykjavík. http://hdl.handle.net/1946/676o

Sigurðsson, R., J. F. Hæibsdæittur, S. G. Halldórsdóttir, and P. Jóhannsson. 1992. Vatnafarsleg flokkun vatnasvæða á Íslandi. [Hydrological classification of drainage areas in Iceland]. OS2006/013, National Energy Authority. https://orkustofnun.is/gogn/Skyrslur/OS-2006/OS-2006013.pdf

Smith, R. 2014. Users and Uses of Environmental Accounts: A Review of Select Developed Countries. WAVES, Washington, DC.

https://www.wavespartnership.org/sites/waves/files/documents/PTEC1-

\%20Users\%20and\%2oUses\%200f\%20Environmental\%20Accounts.pdf

Soderberg, M. and D. N. Barton. 2014. Marginal WTP and Distance Decay: The Role of 'Protest' and 'True Zero' Responses in the Economic Valuation of Recreational Water Quality. Environmental \& Resource Economics 59:389-405. doi: https://doi.org/10.1007/s10640-0139735-y

Statistics Iceland. 2018. Inhabitants overview. https://www.statice.is/publications/newsarchive/population/population-in-the-4th-quarter-2017/

Steen-Olsen, K., J. Weinzettel, G. Cranston, A. E. Ercin, and E. G. Hertwich. 2012. Carbon, Land, and Water Footprint Accounts for the European Union: Consumption, Production, and Displacements through International Trade. Environmental Science \& Technology 46:1088310891. doi: https://doi.org/10.1021/es301949t

Steyaert, P. and G. Ollivier. 2007. The European Water Framework Directive: how ecological assumptions frame technical and social change. Ecology and Society 12:25. doi:

https://doi.org/10.5751/ES-02018-120125

Swedish Water Authority. 2018. www.vattenmyndigheterna.se

Swedish Water Authority of the Bothnian Bay Water District. 2016. River Basin Management Plan 2016-2021 Bothnian Bay Water District - English Summary. County Administrative Board of Norrbotten, Luleå. 
Söderberg, C. 2016. Complex governance structures and incoherent policies: Implementing the EU water framework directive in Sweden. Journal of Environmental Management 183:90-97. doi: https://doi.org/10.1016/j.jenvman.2016.08.040

Tukker, A., T. Bulavskaya, S. Giljum, A. de Koning, S. Lutter, M. Simas, K. Stadler, and R. Wood. 2014. The Global Resource Footprint of Nations. Carbon, water, land and materials embodied in trade and final consumption, calculated with EXIOBASE

2.1.Leiden/Delft/Vienna/Trondheim. http://wedocs.unep.org/handle/20.500.11822/18929

UNEP, United Nations Statistics Division, and Convention on Biological Diversity. 2017. SEEA Experimental Ecosystem Accounting: Technical Recommendations. Project on Advancing Natural Capital Accounting Funded by NORAD.

United Nations, Department of Economic and Social Affairs, Statistics Division. 2012. SEEAWater: System of Environmental-economic Accounting for Water. United Nations.

https://unstats.un.org/unsd/envaccounting/seeaw/seeawaterwebversion.pdf

United Nations, European Union, Food and Agricultural Organization of the United Nations, International Monetary Fund, OECD, and The World Bank. 2014a. System of EnvironmentalEconomic Accounting 2012: Experimental Ecosystem Accounting. United Nations, New York.

United Nations, European Union, Food and Agricultural Organization of the United Nations, International Monetary Fund, OECD, and The World Bank. 2014b. System of Environmental Economic Accounting 2012: Central Framework.

Vanham, D. and G. Bidoglio. 2013. A review on the indicator water footprint for the EU28. Ecological Indicators 26:61-75. doi: https://doi.org/10.1016/j.ecolind.2012.10.021

Vardon, M., P. Burnett, and S. Dovers. 2016. The accounting push and the policy pull: Balancing environment and economic decisions. Ecological Economics 124:145-152. doi: https://doi.org/10.1016/j.ecolecon.2016.01.021

Vatnaskil. 2015. Vatnsvernd á höfuðborgarsvæðinu. Greinargerð um heildarendurskoðun. [Waterprotection in the Capital Area: Report on total revision]. 15.04.

Weitzman, M. L. 1976. On the welfare significance of national product in a dynamic economy. Quarterly Journal of Economics 90:156-162. doi: https://doi.org/10.2307/1886092

Vesterinen, J., E. Pouta, A. Huhtala, and M. Neuvonen. 2010. Impacts of changes in water quality on recreation behavior and benefits in Finland. Journal of Environmental Management 91:984-994. doi: https://doi.org/10.1016/j.jenvman.2009.12.005

Wood, R., K. Stadler, T. Bulavskaya, S. Lutter, S. Giljum, A. de Koning, J. Kuenen, H. Schütz, J. Acosta-Fernández, A. Usubiaga, M. Simas, O. Ivanova, J. Weinzettel, H. J. Schmidt, S. Merciai, and A. Tukker. 2015. Global Sustainability Accounting-Developing EXIOBASE for MultiRegional Footprint Analysis. Sustainability 7. doi: https://doi.org/10.3390/su7010138

World Bank. 2018. Wealth Accounting and the Valuation of Ecosystem Services. https://www.wavespartnership.org/

Ylivainio, K., K. Suominen, P. Fjäder, and L. Äystö. in prep. Potential for sewage sludge phosphorus in plant production and its effects on the environment and food safety. PProduct project final report, Luke, Helsinki.

Image credits:

Icons made by Smashicons, Freepik, and Nikita Golubev from www.flaticon.com 


\section{Exekutiv sammanfattning}

\section{Vad är problemet?}

Enligt aktuella indikatorer för ekonomisk tillväxt (t.ex. BNP) är hållbarheten inte tillräcklig och miljöindikatorerna beaktar inte samhällets ekonomiska behov. Tidigare internationella försök att ta itu med denna fråga har lett till blandade resultat. Både EU (Biodiversity Strategy) och FN (Sustainable Development Goals) fortsätter att kräva åtgärder för att bedöma status och framtid för ekosystemtjänster och deras bidrag till dagens och kommande generationens välfärd. Behovet av systematisk analys av interaktioner mellan ekonomi och miljö har aldrig varit så brådskande.

\section{Vad är det önskade resultatet?}

Omfattande implementering av ett verktyg som anger hållbarheten hos sötvattenekosystemen, deras bidrag till ekonomisk tillväxt och kostnaderna för nedbrytning av sötvattenekosystem; som sedan kan användas som ett bidrag till framåtblickande ekonomiska modeller vid bedömning av ekonomiska och miljömässiga konsekvenser av t.ex. ekonomiska investeringar (massafabriker) eller miljöinvesteringar (t.ex. miljöpolitik, naturskydd).

\section{Status och förslag till lösningar}

Natural Capital Accounting (NCA) kan vara det verktyg som fyller klyftan mellan nuvarande ekonomiska och miljömässiga indikatorer. Utvecklingen av NCA har framskridit och är nu klar för en bredare tillämpning i hela Norden. Bakgrund om de relevanta begreppen naturkapital och ekosystemtjänster, utveckling och tillämpning av NCA, och några pågående utmaningar presenteras alla i samband med nordiska sötvattenresurser i kapitel 1.

Generellt sett förekommer sötvatten rikligt i nordiska arktiska områden, men vattenkvalitetsfrågor kan leda till vattenbrist och ekonomiska förluster. Kapitel 2 ger information om tillgången och kvaliteten på sötvattenresurser i Norden och illustrerar växelverkan mellan de ekonomiska sektorerna och sötvattensekosystemen. Vilka sektorer är vattenintensiva, hurudan förorening de producerar, vad är deras ekonomiska bidrag och hur många jobb de erbjuder?

Europeiska unionens vattenramdirektiv är den viktigaste politiken för hållbar användning av vattenekosystemen i Norden och är starkt synergistisk med utveckling och tillämpning av NCA. Kapitel 3 illustrerar vad direktivet begär och rapporterar och vad som 
kan användas för olika redogörelser. Dessutom visar det hur utarbetandet av redogörelser kan användas för att genomföra de ekonomiska analyser som begärs av direktivet.

Miljöräkenskaperna används redan i stor utsträckning i de nordiska länderna, men utvecklingen och implementeringen är ojämn. Kapitel 4 presenterar den nuvarande statusen för miljöräkenskaperna i Norden, inklusive befintliga redogörelser, användarprofiler, nuvarande utmaningar och framtida utvecklingsplaner. Kapitel 5 illustrerar utvecklingen av vattenräkenskaper för 195 ekonomiska sektorer i Finland och hur informationen kan användas i regional skala. Potentiella tillämpningar för utveckling av vattenutsläppsräkenskaper, vattenfotspår, ekosystemräkenskaper och användningen av input-output modellering diskuteras.

Natural Capital Accounting kan hjälpa till att analysera de ekonomiska och miljömässiga konsekvenserna av investeringar. Kapitel 6 illustrerar avvägningen mellan tillhandahållande och kulturella ekosystemtjänster i monetära termer.

\section{Rekommendationer}

- Utbilda miljöforskare och miljöekonomer om statistiska normer och ramar för miljö- och ekosystemräkenskaperna.

- Testa de befintliga datamängder som följer av miljövärderingsstudier inom en räkenskapsram.

- Utbilda politiska experter inom EU:s ramdirektiv om hur de skulle kunna bidra till utvecklingen av ekosystemräkenskaper och hur de kunde tillämpa räkenskaperna för att ge informerad politisk rådgivning.

- Tilldela resurser för utveckling av miljö- och ekosystemräkenskaper och deras regelbundna uppdateringar, t.ex. vart femte år.

- Användning av räkenskapsinformation för att utveckla indikatorer för hållbara utvecklingsmål.

- Integrera miljömässiga och ekonomiska räkenskapningarna med ekonomiska modeller för att analysera effekterna av investeringar och politik. 
Nordic Council of Ministers

Nordens Hus

Ved Stranden 18

DK-1061 Copenhagen K

www.norden.org

\section{Arctic Freshwater Natural Capital in the Nordic Countries}

Current indicators of economic growth (e.g., GDP) do not adequately consider sustainability, while environmental indicators alone fail to acknowledge the economic needs of a society. Natural Capital Accounting (NCA) can be the tool that fills the gap separating current economic and environmental indicators. Development of NCA has progressed considerably and is being widely deployed in the Nordic countries, but development and deployment remain uneven. This report provides background on NCA and its associated accounting frameworks, demonstrates the applicability of NCA for sustainably utilizing freshwater resources in the Nordic Arctic and provides recommendations for maximizing the value of environmental accounting as an economic, environmental, and sustainable development tool. 